



\section{HISTORIOGRAFÍA, PERSONA Y NACIÓN}





\author{
Dalia Carreño Dueñas \\ David Valencia Villamizar
}

\title{
HISTORIOGRAFÍA, PERSONA Y NACIÓN
}

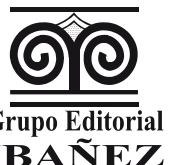


(C) Dalia Carreño Dueñas

David Valencia Villamizar

(C) Universidad Santo Tomas

Carrera 9 No. 72-90

Facultad de Derecho

Bogotá - Colombia
(C) Grupo Editorial IbÁÑez

Carrera 69 Bis № 36-20 Sur

Teléfonos: 2300731 - 2386035

Librería: Calle 12B № 7-12 L.1

Tels.: 2835194 - 2847524

Bogotá, D.C. - Colombia

www.grupoeditorialibanez.com

ISBN: 978-958-749-622-2

Diseño de carátula: Kevin Nuñez

Diagramación electrónica: Deissy Alejandra Rodríguez

Queda prohibida la reproducción parcial o total de este libro por cualquier proceso reprográfico o fónico, especialmente por fotocopia, microfilme, offset o mimeógrafo.

Ley 23 de 1982

(R) 2016 


\section{COMITÉ CIENTÍFICO}

Manuel Horacio Vásquez

Doctor en Historia Universidad de Nantes, Francia.

Profesor e investigador Universidad del Tolima

Dr. Félix Raúl Martínez

Doctor en Historia Universidad Nacional de Colombia.

Profesor e investigador Universidad del Tolima

\section{COMITÉ EDITORIAL}

Bernd Marquard

Doctor en Historia Universidad St. Gallen, Suiza.

Profesor e investigador Universidad Nacional

Henry Bocanegra Acosta

Doctor en Sociología Jurídica

Universidad Externado de Colombia

\section{PARES ACADÉMICOS}

Hugo Fernando Guerrero Sierra

Doctor en Derecho - Universidad Complutense de Madrid.

Profesor Universidad Pedagógica y Tecnológica de Colombia UPTC

Roch Charles Little

Doctor en Historia - Universite Laval

Docente Universidad Nacional 



\section{CONTENIDO}

PRESENTACIÓN

\section{EL CONCEPTO DE NACIÓN \\ EN LAS CONSTITUCIONES POLÍTICAS \\ COLOMBIANAS DEL SIGLO XIX AL SIGLO XX}

INTRODUCCIÓN

1. EL CONCEPTO DE NACIÓN 14

2. EL POSIBLE CONCEPTO DE NACIÓN COLOMBIANA

EN LOS PROCESOS DE CONQUISTA, PACIFICACIÓN Y COLONIA 18

3. EL CONCEPTO DE NACIÓN EN LOS TEXTOS MAGNOS 24

CONCLUSIONES 44

BIBLIOGRAFÍA 44

MIGUEL ANTONIO CARO

Y LA CONSTRUCCIÓN HISTÓRICA

DEL CONCEPTO DE PERSONA

CAPítulo UnO

EL SIGLO XIX COLOMBIANO Y LA REGENERACIÓN

1. EL CUENTO DE UN PROTOCOLIZADO PASADO...............................................47

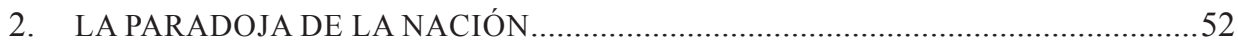

3. LA REGENERACIÓN Y LOS DISPOSITIVOS NORMALIZANTES.........................54

4. LA CONFECCIÓN HISTÓRICO- GEOGRÁFICA DE LA NACIÓN ...........................56

5. EL DISCURSO DE LA IDENTIDAD

ENTRE LA FRAGMENTACIÓN Y EL CONSENSO 60 
6. EL RÉGIMEN ECONÓMICO EN COLOMBIA DURANTE EL SIGLO XIX ............62

6.1. SISTEMA DE HACIENDA Y RELACIONES DE PRODUCCIÓN EN LA SEGUNDA MITAD DEL SIGLO XIX 65

7. ¿CUÁL PRINCIPIO DE IDENTIDAD NACIONAL? 68

\author{
Capítulo Dos \\ MIGUEL ANTONIO CARO \\ Y LA CONSTRUCCIÓN DEL CONCEPTO DE PERSONA
}

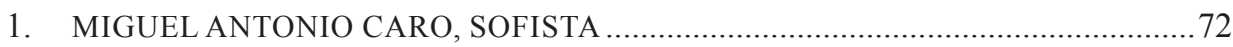

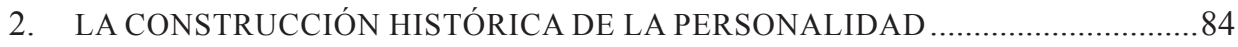

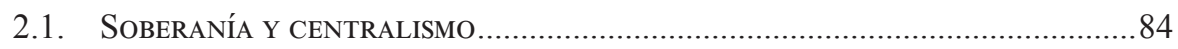

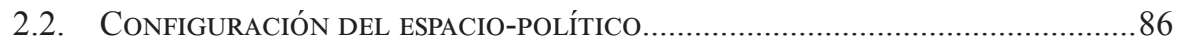

2.3. El pensamiento económico de Miguel Antonio Caro............................... 88

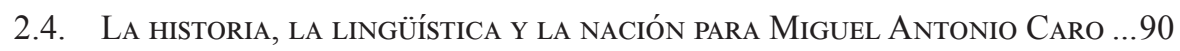

2.5. EL ORDEN CATÓLICO Y LA TRADICIÓN HISPÁNICA............................................94

2.6. INMIGRACIÓN, RELIGIÓN Y CONSTRUCCIÓN

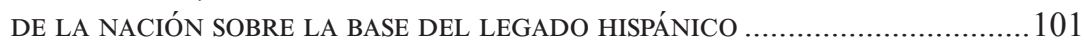

2.7. El HOMBRE PÚBLICO COMO ARQUETIPO. LA PASTORAL CRISTIANA ..................104

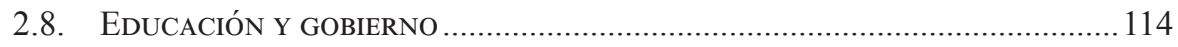

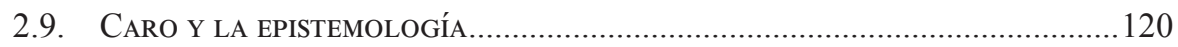

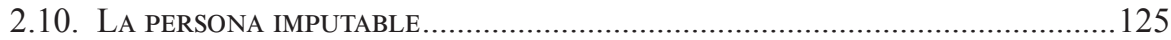

2.11. El paradigma: Miguel Antonio Caro y Andrés Bello...........................128

2.12. LA “Cuestión Social” PARA Miguel Antonio CARo .....................................135

2.12.1. El concepto de necesidad ............................................................ 135

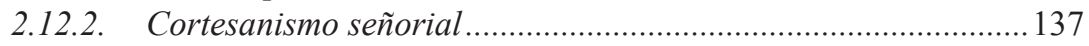

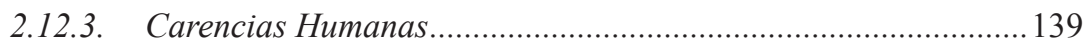

2.12.4. El aspecto moral de la cuestión social ................................... 142

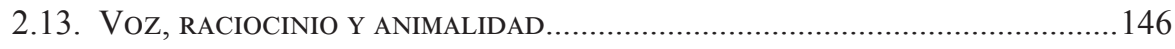

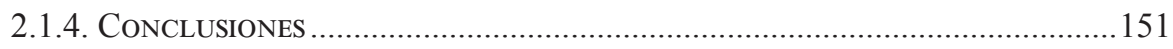

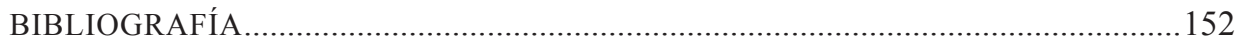




\section{PRESENTACIÓN}

Los trabajos que componen este volumen se ocupan críticamente de los mecanismos históricos de construcción del concepto de "Nación" en Colombia. El primero de ellos, escrito por la Dra. Dalia CARREÑo asume una dirección analítica e investigativa más imantada por el Derecho Constitucional y la cimentación del Estado de Derecho desde la Ciencia política. Así las cosas, se comienza con consideraciones que hunden sus raíces en el período colonial, sin descuidar las categorías analíticas dimanantes del pensamiento constitucional moderno, hasta llegar a un tumultuoso siglo XIX con su colofón regeneracionista.

El capítulo del Dr. David Valencia toma el relevo en ese justo período histórico explorando referentes epistemológicos que condicionan el tramado del relato histórico en tanto artificio narrativo. Se revisan estilos de escritura, regímenes de metaforización, intereses y plantillas de legibilidad operando como planos de consistencia en la labor de los historiadores. De esta suerte se ofrecen dos perspectivas perfectamente complementarias que dan una mirada plural al fenómeno de consolidación de la identidad colectiva en nuestro país.

En tanto elemento axial de la ciencia política occidental, la nación como conjunto cultural, económico, político y jurídico de singularidades sigue siendo objeto de polémicas, debates y paradojas. La constatación indudable del fracaso de esta noción para agrupar una multiplicidad étnica heterogénea en nuestro continente es algo que no se cuestiona, de allí la tarea de desconstruir los referentes, las narrativas, los discursos, las prácticas y las representaciones que han pretendido cimentar la nación entre nosotros.

Ese sería el vector enunciativo que como eje temático anima este libro: brindar un escenario de comprensión expandido acerca de los avatares socio-linguísticos y propiamente institucionales en la fabricación de un referente colectivo particularmente en el siglo XIX. Escoger el período de la regeneración ofrece ventajas hermenéuticas claras. Al situarse en el momento de emergencia de la constitución de 1886, se puede atisbar un paisaje político con particularidades hispanofílicas, católicas, centralistas 
y ciertamente autoritarias que van a ser decisivas en la configuración de nuestra "colombianidad".

De allí que rastrear desde los discursos, prácticas enunciativas y actuaciones verbales de Miguel Antonio Caro, por ejemplo -en tanto personaje conceptual-, este montaje histórico específico, con pretensiones de autoridad indiscutible, resulta fecundo y pertinente a la vez. Se proponen plexos problemáticos ligados a inercias decimonónicas en los actuales procesos políticos colombianos, en donde el legicentrismo, la burocratización excesiva, las rivalidades regionales a nivel de economía política y las pugnas inter-élites destacan como elementos relevantes.

Más allá de la psicoanalítica "compulsión de repetición" que acecharía el desconocimiento del pasado de un pueblo, es la temporalidad de las guerras civiles y el estado de excepción como mecanismo de normalización del sistema político, los que gravitan como una presencia fantasmática el pasado histórico de una nación como Colombia. Situaciones de marcada exclusión social de la mano de la importación de modelos de pensamiento (económicos, políticos y sobretodo culturales) euro-céntricos, también dan rostro a esta realidad convulsa y en crisis permanente, desde el siglo XIX hasta nuestros días.

Finalmente, siempre de acuerdo a las inexorables y amigables exigencias institucionales de Colciencias, se aclara que este libro es resultado de la línea "Historia, Cultura y Derecho", con su correspondiente proyecto de investigación adscrito al grupo "Socio-Humanística del Derecho" del Centro de Investigaciones "Francisco de Vitoria" de la Facultad de Derecho de la Universidad Santo Tomás. Además de los propios méritos historiográficos exhibidos en estos capítulos, el libro es un valioso ejemplo de cohesión en los empeños de producción de conocimiento del mencionado grupo.

DaVid VALENCIA

Compilador académico 


\title{
EL CONCEPTO DE NACIÓN \\ EN LAS CONSTITUCIONES POLÍTICAS \\ COLOMBIANAS DEL SIGLO XIX AL SIGLO XX
}

\author{
Dalia Carreño Dueñas ${ }^{1}$ \\ A la Nación "estamos unidos por la inmovilidad \\ de los sepulcros y el Vaivén De Las Cunas" \\ Maurice BARRÉS
}

\section{INTRODUCCIÓN}

En este trabajo historiográfico ${ }^{2}$, se aborda la manera como el concepto de Nación, ha estado presente en los desarrollos del pensamiento constitucional colombiano. Noción aunque de reciente incorporación en la reflexión de la filosofía política, es de gran importancia para determinar la forma como se piensa, se comprende y se proyecta el hoy denominado Estado constitucional; esta categoría se instituye en compleja, paradójica, pluralista y de manera fuerte está siempre en construcción, pues se trata de configurar una unidad política de acción.

La unidad política de acción que denominamos Estado, no es hoy, como se presupone en la descripción de Jellinek, algo que venga sin más dado (...) tiene que labrarse y asegurarse en el proceso político de la moderna sociedad pluralista; en la yuxtaposición y la contienda de numerosos grupos, en los que la compensación entre las diferentes opiniones, intereses

1 Licenciada en Filosofía y Letras, Licenciada en Filosofía y Ciencias Religiosas, Abogada, Especialista en Derecho Penal, Magister en Educación, Doctoranda en Derecho Universidad de Buenos Aires. Docente Universidad Santo Tomás Colombia. Miembro del grupo de Investigación Social y Humanística, clasificado en COLCIENCIAS D. Correo : daliacarreno@usantotomas.edu.co

2 Este capítulo es resultado de investigación del proyecto de la línea Historia, Cultura y derecho, denominado "Genealogía del concepto de Nación, Colombia, siglo XIX" adscrito al grupo de Investigación socio-humanística del derecho (GISHD) de la Facultad de Derecho de la Universidad Santo Tomás Bogotá. 
y aspiraciones, como la resolución y regulación de conflictos, se han convertido por igual en tarea arquetípica y en condición de existencia del Estado (Hesse, 2001, p. 3).

La pregunta que guía este trabajo es ¿cuándo surge la nación colombiana? y una de sus posibles respuestas, es la consideración desde el estatuto constitucional, desde el orden legal, sin desconocer la carga simbólica de las construcciones culturales, sociales e históricas que incidieron e inciden en su creación, incluso las estructuras institucionales precolombinas, que como imaginario colectivo también terminan por configurar esta compleja y sui generis nación.

En primer lugar es necesario señalar, el surgimiento y la construcción filosófica y política de la idea de Nación y sus elementos sustanciales. En segundo lugar se aborda una propuesta de índole histórica para ubicar una posible edificación de Nación Colombiana desde la irrupción española en el siglo XVI y los consecuentes procesos de conquista, pacificación y colonia. En tercer lugar desde la mirada teórica de nación, se revisa la manera como ésta ha sido incorporada en los Textos Magnos como el Acta de Independencia de 1810, la Instalación del Congreso el 22 de diciembre de 1810 y las nueve Cartas Políticas colombianas de ámbito nacional: Ley Fundamental de la Unión de los Pueblos de Colombia del 18 de Julio de 1821, Constitución Política de la República de Colombia de 1830, Constitución del Estado de la Nueva Granada de 1832, Constitución de la República de la Nueva Granada de 1843, Constitución de la República de la Nueva Granada de 1853, Constitución de la Confederación Neogranadina de 1858, Constitución de los Estados Unidos de Colombia de 1863, Constitución Política de la República de Colombia de 1886 y la Constitución Política de la República de Colombia de 1991.

\section{EL CONCEPTO DE NACIÓN}

El concepto de nación se había empleado desde la edad media según $\mathrm{Chabod}^{3}$, como equivalente a provincia o región; las universidades, los comerciantes, los Concilios, las ferias se dividían por naciones para su organización y estructura: "en los grandes concilios y también en

Desarrollado en la obra del autor, La idea de nación, publicada por el Fondo de Cultura Económica en 1987. 
otras ocasiones, como cuando se habla de los comerciantes de la nación "lombarda" en Francia en el siglo XIII" (Naranjo, 2003, p. 95). Así para el siglo XV este refería al lugar de nacimiento, la Universidad de Paris denominaba nación a un grupo de personas que venían del mismo lugar. En España en los siglos XVI y XVII su empleo se amplía a los ámbitos de la estirpe, la región, el reino o pueblo, y entrado el siglo XVII y XIII, su acepción involucra la idea diferenciadora de raza "la nación está fundada en la raza (...) la raza venía a ser el vínculo natural, ab inmemorabile, al que se referían algunos autores, sobre el cual ser organizaba el poder político" (Silva, 2000, p. 175), y con este uso discriminatorio se instaura un criterio de organización política:

En la España del siglo de oro su uso estaba relacionado con el nacimiento, el linaje $\mathrm{u}$ origen, pero en otros aspectos se advierte también su equivalencia a territorio, república, reino y pueblo. En los siglos XVII y XVIII esta acepción amplía su referencia a los diversos grupos populares, acentuando sus caracteres diferenciales en la raza (Silva, 2000, p. 175).

La filosofía política de Rousseau, inserta la idea de nación, idea paradójica porque reconoce las dificultades de la vida en común, y de identificar la existencia de un elemento unificador claro y evidente, critica los ideales humanitarios y cosmopolitas de la ilustración, "Dígase lo que se diga, hoy no quedan ya franceses, alemanes, españoles, ni siquiera ingleses; no hay sino europeos...Siempre que encuentran dinero que robar y mujeres que corromper, se encuentran en todas partes en su casa" (Sabine, 2002, p. 452), por la falta de principios morales, pese a esta postura reconoce la ciudadanía como expresión del sentimiento nacional: "calumnió reiteradas veces a los ideales humanitarios y cosmopolitas de la Ilustración calificándolos de mera falta de sentimientos morales (...) contribuyó a refundir el antiguo ideal de la ciudadanía en una forma tal que pudo apropiárselo el sentimiento nacional" (Sabine, 2002, p. 452)

La idea de Nación más allá de esta referenciación, no había estado tan presente en el pensamiento de la teoría y la historia política occidental, con Sieyès ${ }^{4}$ en el siglo XVIII se inaugura esta concepción socio-histórica: "fenómeno sociológico e histórico de la edad moderna" (Sáchica, 1962, p. 123) como propia de la modernidad, e importante para el constitucionalismo

$4 \quad$ Quien se desempeñó como vicario de la Diócesis de Chartes, y como representante del poder eclesiástico ante los Estados Generales presididos por Luis XVI. 
contemporáneo, abocado a la globalización y a las crisis y conflictos dados por los nuevos órdenes mundiales. Esta idea de Nación, propuesta por Sieyès surge en el escenario de la revolución francesa, que conllevó a repensar la dinámica social de visibilidad y participación de todos en el poder político. El nuevo orden del mundo francés lleva a plantearse que aparte de la nobleza y del clero existen Otros, denominados como el tercer Estado, ubicado entre la burguesía y el pueblo: "Tercer Estado, algo a medio camino entre la burguesía (con todos los matices con que debe usarse esta noción para la Francia del siglo XVIII) y el pueblo)" (Botella, et al, 1998, p. 307. Se pregunta Sieyès ¿qué es el Tercer Estado? él responde de modo radical: Todo; y a la pregunta qué ha sucedido con este Tercer Estado y su acceso a la función pública, su contestación es también tajante ¡nada! (Sieyès, 1973, p. 3). La propuesta del clérigo francés es que el Tercer Estado ocupe el lugar que les corresponde en el gobierno de los destinos comunes. Advierte que el Tercer Estado "es una nación completa" (Botella, et al, 1998, p. 307).

Todos los que integran la Nación, desempeñan labores necesarias para la subsistencia de esta, considera Sieyès que son cuatro: la primera dedicada los trabajos del campo, los segundos a la industria humana, los terceros al comercio y a los negocios y la cuarta a las profesiones científicas y liberales desde las más connotadas a las más humildes. Toda la labor que despliega la sociedad para existir y coexistir son "los que mantienen a la sociedad. ¿Sobre quién recaen? el Tercer Estado" (Sieyès, 1973). De este presupuesto se deprende que uno de los elementos que identifican a la Nación, es el hecho de ser una agrupación, una asociación unida por labores que benefician a todos y por un sentimiento de democracia, y común unión de aportación. Quizá se podría afirmar que la idea de Nación surge al interior del mundo demócrata, inclusivo y de alteridad; alteridad que se traduce en la idea de voluntad colectiva, aspecto de la voluntad que caracteriza la concepción francesa de Nación: "al lado de los elementos étnicos, hay que tener en cuenta los acontecimientos históricos, los intereses comunes y, sobre todo, los lazos espirituales; en una palabra, el voluntarismo" (Hauriou, 1980).

Como parte esencial de los elementos estructurales de la Nación, según el clérigo francés, se encuentra el "conjunto de ciudadanos que pertenecen al orden común" (Sieyès, 1973, p. 6) que una vez que se arraigan ${ }^{5}$ han

Más allá de identificarse con el nacimiento, o la estirpe de la cual se desciende, es la existencia actual, la vida común que se comparte, entre otras porque advierte SIEYÈs, 
de entender la nobleza, como el estatus que se origina y se concede, por pertenecer al Tercer Estado. Bajo esta perspectiva se debe examinar el asunto discriminador del ejercicio de las funciones públicas, que están en cabeza de los privilegiados, como quiera, que estas producen lucro y honor y no están en manos del Tercer Estado. Dichas funciones el clérigo las agrupa en cuatro: la Espada, la Toga, la Iglesia y la administración, labores a su juicio penosas, y de las que se sustraen los privilegiados quienes tienen el monopolio de la función pública:

La Espada, la Toga, la Iglesia y la Administración. Resultaría superfluo detallarlas para ver que el Tercer Estado constituye los diecinueve vigésimos de las mismas, con la diferencia de que está encargado de todas las tareas penosas, de todas las ocupaciones que el orden privilegiado se niega a cumplir. (Sieyès, 1973, p. 5).

El Tercer Estado según el Abate no ha llegado a ser, a ser Nación, porque no gozan de una ley y una representación común, como quiera que no pueden acceder a la función pública. Esta proclama de Sieyès, es el fundamento de las teorizaciones modernas sobre la Nación, que para el siglo XIX, se ubican en dos tendencias la francesa y la alemana. La corriente francesa centra su comprensión de la nación, sobre los lazos espirituales que crean y juntan la vida de los hombres entre sí "una Nación era "una mentalidad" (Hauriou, 1980, p. 120) se trata de una mentalidad, de intersubjetividades que pueden hacer lecturas de vida comunes. La corriente alemana, centró el concepto de Nación, en elementos cuantificables como la geografía, la lengua, la religión y de manera prioritaria la raza, así la síntesis de suelo, sangre y lengua, con la fuerza simbólica y de representación como pueblo elegido, con una misión de supremacía:

El volk (pueblo, nación) aparece en la ideología nazi, como una comunidad tribal fundada sobre la sangre, el suelo y la lengua (...) Así es cómo el volk alemán debe contener todo el conjunto germánico, tanto más cuanto que esta noción de Volk implica la idea de que se trata de un pueblo elegido. (Hauriou, 1980, p. 120).

Idea ésta de Nación que facilitó el ascenso de Nazismo y la exterminación del pueblo judío. La tendencia alemana de la Nación, es superada por el

luego de la historia de invasión y conquista de Francia, ya no quedan tan claros los linajes. Las castas sólo son importante para los privilegiados, para justificar el poder de quienes gobiernan. 
pensamiento francés que marca el sello identitativo de la Nación como el de proyecto de vida en común (Hauriou, 1980, p. 120), teniendo en cuenta que este concepto es complejo e integra aspectos diversos que van desde la lengua, la raza, la religión, acontecimientos históricos, hambrunas, prosperidad; las forma económicas, y el parentesco espiritual entre otros. Todo lo anterior, junto, configura el espíritu nacional de una sociedad, el sentido y el significado que otorga el sentirse parte de algo "da a sus individuos el sentimiento de pertenecer a un grupo cerrado, a un conjunto que se encuentra en oposición a otras formaciones nacionales" (Hauriou, 1980, p. 121). La representación de cómo se tejen los hilos de la Nación, considera Duguit, dependerán de las vivencias en común de cada grupo social, será el resultado de complejos y largos procesos sociales, históricos, jurídicos, culturales; no se presenta de manera espontánea porque la Nación conjuga la tradición del pasado con las aspiraciones del futuro: "El sentimiento nacional consiste en considerar a la Nación como el símbolo unitario de intereses, aspiraciones, sentimientos y glorias comunes" (Naranjo, 2003, p. 94).

Como elemento integrador del pensar de la nación, está el carácter histórico, el poder dar cuenta de quién se es, de la individualidad histórica "comunidad consciente o asentida, cuantitativamente superior y cualitativamente distinta a los grupos que la integran o como dice Davin, "un querer colectivo" fundado sobre realidades y hechos sociales de carácter permanente que la califican y personalizan" (Sáchica, 1962, p. 125); de lo auténtico de la razón de lo particular, de aquellas notas características que facilitan el reconocimiento y la inclusión. Ser Nación es ser común-unidad nacional, es exaltación y reconocimiento de lo propio.

Finalmente Subyace a la teorización sobre la Nación un elemento anímico, que lleva a entender más allá de las formulaciones escritas, lo que constituye lo propio de lo social y la apuesta por la fraternidad y las acciones de solidaridad que confluyen en los ideales de bienestar y justicia.

2.

EL POSIBLE CONCEPTO DE NACIÓN COLOMBIANA EN LOS PROCESOS DE CONQUISTA, PACIFICACIÓN Y COLONIA

Acerca de un posible origen de la Nación Colombiana

La historia de la Nación Colombiana hunde sus profundas raíces en las comunidades que habitaban estas tierras; pobladores que sin pertenecer a 
grandes reinos como el maya, o el quechua configuraron estructuras sociales, políticas y jurídicas eficaces. Sin embargo con la intrusión de España, buena parte de la Nación o más bien de las naciones existentes desaparecieron, bien bajo el poderío militar bien bajo la explotación laboral a que fueron sometidos.

Una breve reseña de la situación de los nacionales que existían quieta y pacíficamente:

La conquista española se llevó a cabo en las tierras colombianas, entre el periodo de 1500 a 1550 . Los primeros territorios que son conquistados (invadidos) son los del litoral caribe y la región andina. En esos cincuenta años se fundan ciudades que se constituirán en los centros políticos de la nueva Nación, entre ellas están Santa Marta, Cartagena de Indias, Santa Fe, Tunja, Popayán, Vélez, Cartago y Cali. (Salazar, 1994).

Antes del siglo XVI, se permite hacer una comprensión y sentido de la forma como Colombia ha intentado construido la categoría de Nación, y con seguridad explicar porque en los albores del siglo XXI, aún está la expectativa por construir y solidificar la Nación colombiana, por dar cuenta de su identidad, de lo esencial de su cultura. La historia del sometimiento tiene presupuestos y justificaciones que son válidas y que poseen el amparo constitucional del imperio Español.

Los conquistadores, hacen el requerimiento debido a los indios esta exigencia estaba consagrada en los ideales del Orbe cristiano, y en la imposición de una conciencia espiritual superior sobre individuos infieles, con duda de la poseían de un alma "antes de hacerles la guerra (...) En dicho Requerimiento se sintetiza admirablemente la concepción del Orbe cristiano y la justificación de la "conciencia Real" de sus derechos sobre la conciencia americana" (Salazar, 1994, p. 21). Una vez conquistados con el poder y por la fuerza de las armas, con la introducción de enfermedades, con la seducción por una cultura extranjera y en gran parte por los imaginarios de los indígenas sobre los europeos "antes de hacerles la guerra (...) En dicho Requerimiento se sintetiza admirablemente la concepción del Orbe cristiano y la justificación de la "conciencia Real" de sus derechos sobre la conciencia americana” (Salazar, 1994, p. 21).

Los españoles organizaron la estructura del vasallaje, que convirtió a los indígenas libres y autónomos, en súbditos con un poder político y un gobernante fuera de su tierra, al que jamás vieron, pero al que debían obediencia, respeto y la entrega de sus tierras, pertenencias y hasta de sus propias vidas. Hasta este momento no es posible sugerir la idea de nación 
en sentido fuerte en estas tierras, por la crisis y fractura general, por el aniquilamiento espiritual que causó la devastación española, cuya forma de construcción del tejido social, se hace con Otro, que es extraño, ajeno y ante todo violento, negador, excluyente:

La nación colombiana comienza su existencia histórica precisamente en este periodo de conquista. Periodo de crisis total: crisis en la manera de ser de las culturas precolombinas; crisis en la manera de ser del emigrante español en calidad de conquistador. Surgimiento de la dependencia estructural de nuestra nacionalidad; simbiosis cultural entre las distintas culturas que nos conforman y el desarrollo subsiguiente de una historia que va tomando forma política, económica, cultural, social y religiosa" (Salazar, 1994, p. 33).

Una vez superado el periodo de conquista, entre los años 1550 y 1600 , lo que podría ser la pre-Nación colombiana vive el periodo de pacificación ${ }^{6}$ en el cual, los españoles ya dueños formalmente de estas tierras, implantan instituciones de todo nivel como forma de control y regulación de esta nueva sociedad. Instalan la Real Audiencia de Santa Fe en 1550, obispados en cada capital de gobernación, establecen tasas de tributos a los indígenas; encausan la economía hacia la minería, la gobernación de Antioquia va a ocupar un lugar fundamental en esta explotación de minerales tanto que a partir del siglo XVII, el oro se erige en el referente social, cultural, anímico, el oro es el despliegue de la vida misma, es el alma, su fundamento: “ $;$ Todo (no) es nada ni vale nada ni se puede de ello hacer nada, como no haya oro, ique es el ánima de todo lo dicho y de lo que más sé decir! Y faltando este, todo falta" 7 .

Este supuesto del oro, es sin duda la paradoja social más relevante en este colectivo conflictivo paradigmático, conformado por invasores e invadidos, como quiera que por un lado se configuraba en la aspiración del proyecto de vida español, como criterio unificador de los ideales de su felicidad y por otro lado significó la tragedia para el indígena, pues lo postró en la indignidad de un trabajo esclavo. La desigualdad y la inequidad son la

6 Mediante estructuras administrativas y militares, por parte de los conquistadores, que se asentaron luego del exterminio y la dominación de las tierras, bienes y personas de los nativos.

7 Esta es parte de la misiva que envían Sebastián Magaña, Andrés Moreno y Luis de Guevara a la Sacra Católica Cesárea Majestad, para que se oriente la economía hacia la Minería, en la gobernación de Popayán. 
impronta de esta nueva posible Nación, que se construye sobre beneficios para los conquistadores españoles y exclusión, pobreza y servidumbre para los indígenas. El Estado y el orden jurídico en Colombia, se instituyen para el beneficio del español encomendero (dueño verdadero y definitivo del poder económico y militar) y se hace a través de una acomodada Real Audiencia:

Se pregunta Alejandro López, acerca del papel de los encomenderos "Sería muy interesante que personas expertas en la legislación con que la naciente República remplazó las leyes y disposiciones españolas, nos mostrasen sí las nuevas instituciones republicanas vinieron a satisfacer o no el clamor de los pueblos contra el monopolio dado a los encomenderos y grandes señores territoriales por los agentes de España" (López, 1976, p. 40).

La impunidad y la ofensa de la injusticia frente a los delitos perpetrados por los españoles son evidentes, tanto que se pide a la Corona española que se indulten los crímenes viejos, cometidos por los conquistadores porque ya ellos, están pacíficos y cansados: olvido sin más, injusticia extrema: "son innumerables las muertes e invenciones de crueldades hechas en indios (...) nos parece que Vuestra Majestad debería mandar sobreseer estos delitos viejos" 8 .

La pacificación, había logrado insertar de manera violenta y cruel un nombre, una religión, una sociedad, una economía, una política y una cultura extraña a esta tierra de los ahora Novo nativos Neogranadinos. La transformación es sustancial trae consigo un nuevo hombre: el mestizo, una nueva naturaleza pues el territorio con la apertura de caminos reales, va a configurar esta nueva Nación, que con los caminos trazados en el descubrimiento, la conquista y la colonia, también se trazó el camino espiritual y las rutas de un conjunto social paradigmático "la nación se formó sobre los Caminos del Descubrimiento y la Conquista y se consolidó sobre los de la Colonia" (Moreno P. \& Melo, G., 2010).

La asunción de la colonia, en el siglo XVIII, presenta un panorama complejo de la realidad de esta nueva Nación, denominada como la tardía edad media colombiana. Porque mediaba entre dos siglos el XVI de las conquistas y el XIX de la emancipación, definitivos para la fundación de esta República emergente (Zabalza, 1992), que se asienta y define como colonia periférica, como una aldea:

8 El oidor Montaño solicita a la Corona, en 1554 que todos los crímenes perpetrados por los conquistadores debían ya ser perdonadas, miles de víctimas y todas las torturas aplicadas, ya eran cosa del pasado. 
Pese a ocupar mayor extensión que la actual Colombia, el Nuevo Reino entrado el siglo XVIII, no sobrepasaba en mucho el millón de habitantes (...) Santa Fé, la capital Virreinal, aunque con rango de ciudad, como otros centros urbanos menores, era en realidad un aldea (Zabalza, 1992, p. 116).

A pesar de esta situación aldeana, se contaba con centros educativos universitarios, como el de la Tomista y el de la Javeriana, regentada por religiosos Dominicos y Jesuitas respectivamente, quienes en todo caso, reproducían el conocimiento del centro de poder científico, con la tardanza del advenimiento o al menos del despertar del esquivo espíritu científico. La reproducción cultural va marcando el ritmo de la construcción de la posible nación colombiana, mestiza en su esencia, realidad y acción.

Cabe señalar que en el Virreinato de la Nueva Granada en este siglo, vivió a diferencia de las otras naciones de América Latina, un rápido y creciente proceso de mestizaje, "Según censo de 1788, la composición del país tenía la siguiente composición étnica: blancos (españoles y criollos) 290.599, Mestizos 391.869, Indígenas 151.785 y 57.077 esclavos”. Jaramillo, 1994, p. 109. Lo que significó el cruce de sentidos, significados, comprensiones, mundos de vida de dominadores y dominados; con un lenguaje, una palabra que son comunes, pero que son la expresión de sujeción, de menoscabo, de fortaleza y debilidad manifiesta en los mundos de vida, que se expresan. Esta hegemonía de la palabra del vencedor, se instaura en cumplimiento de la orden de Carlos III que determinaba hablar sólo castellano, "Castellanización de las regiones centrales del país, la costa caribe y parte de las sabanas orientales" (Pineda, 1997) hablar otro idioma era sinónimo de barbarie, o expresión de un ser corrompido como aquel que hablara portugués.

Este carácter mestizo de la Nación colombiana en el siglo XVIII, permite cristalizar, una conciencia del reconocimiento para la construcción y reconstrucción de las bases de un Estado igualmente mestizo, con unas instituciones, un orden político, económico y un constitucionalismo hibrido: "no logró la Nación Colombiana romper "la tradición y la concepción providencial del mundo. Esto es cuando asume la responsabilidad de hacer su propia historia, cuando deja de ser pasivo y se convierte en protagonista, en autor de su vida" (Sáchica, 2002).

La mezcla étnica, trasciende lo meramente racial porque permite ubicar esta república colombiana como una pre-Nación de yuntas, entretejida y aún por asumir lo digno y lo indigno en esta juntura de razas, lenguas, creencias e imaginarios colectivos. En esta época de ilustración de la Nueva Granada lo 
mestizo era considerado como tabú, y como la explicación a los desórdenes, caos y males que padecía el virreinato; el mestizo es recriminado y no tenía lugar en el estatus de alcurnia criolla, blanca y española. El mestizo representa el oprobio del sometimiento y la diversidad, fruto de la violencia:

Hacia 1500 hallaron aquí los españoles millón y medio de gentes, y hacía 1819 dejaron otro millón y medio, mas no de la misma estirpe y cultura, sino contradictoria y diversa, no hermanada y uniforme, antes desigual y confusa. El organizador de la Republica fue tataradeudo de don Francisco Martínez de Rivamontán Santander, gobernador de Santa Fe, y de doña Ana Sáenz, de Suba, cacica, mas no era ya ni lo uno ni lo otro, sino sui géneris. (López de Mesa, 1970, p. 109).

Esta mixtura da color a la pre-Nación colombiana, sui generis, opaca y confusa que para el siglo XIX, reclama por sus derechos mancillados y negados desde el siglo XVI, presenta unas vivas disposiciones anímicas y morales diversas, diferentes. Un nuevo Otro, surge como ciudadano en el siglo XIX, que reclama reconocimiento, inclusión y por supuesto independencia. El negro, ahora emerge y se sitúa en la geografía de esta nación, que esta signada por tres riquezas étnicas, culturales, anímicas, junto al indígena y el español, ya se han fundido y este Otro, conformado por otros, instituye una: "topología moral del territorio (...) fundamental para comprender el proceso de formación nacional". (Pineda, 1997, p. 111).

Los habitantes de los Andes, donde residían mayormente blancos y criollos era el centro de la civilización por antonomasia, los demás habitantes más cercanos a la vida estrecha con la naturaleza se consideraban salvajes. Los esclavos negros habían iniciado valientes procesos de resistencia a su condición, a través de los palenques y el cimarronaje: "Describe Orlando Fals Borda, citado por (Uribe, 1978), la situación el negro que como grupo étnico se había mantenido, ajeno a los procesos del mundo criollo y que se hallaban refugiados en Palenques (caseríos defendidos por estacadas y trampas denominadas palenques)",

Así es aventurado señalar que en la conquista y en la colonia está conformada la Nación colombiana, pues se presenta y se manifiesta un grupo humano fragmentado, diverso, plural, mestizo, con una valor espiritual en construcción, porque su historia es reciente, impuesta, violenta, sin autoreconocimiento, paradójica, avergonzada de sus identidades; apenada, cercana a una psicosis que se generaliza, quizá por la falla del elemento simbólico discursivo que funda, que configura. 
La emancipación del 20 de julio de 1810, ¿el origen de la Nación Colombiana?

El siglo XIX trae consigo las bases, condiciones y contextos sobre los que se podría cimentar y consolidar una posible Nación colombiana; este proceso de edificación se configura como un asunto paradójico y contradictorio del carácter y la búsqueda del espíritu nacional emancipador. Emancipación que se desarrolla en dos fases, la primera de 1810 a 1815 en donde el centro de las revueltas es el Cabildo, de ahí el nombre dado de Revolución de los cabildos. Para el año de 1816 se inicia la retoma del antiguo invasor Español, iniciando con ello la segunda fase de índole militar, de respuesta militar. Estas complejidades históricas se ven reflejadas en las intenciones e intereses consagrados en esta Hoja de Ruta de la vida colombiana. La primera revolución de los Cabildos se consiga en el Acta de Independencia del 20 de julio de 1810, a las seis de la tarde:

la Constitución de Gobierno debieran formarse sobre las bases de libertad e independencia respectiva de ellas, ligadas únicamente por un sistema federativo, cuya representación deberá residir en esta capital, para que vele por la seguridad de la Nueva Granada que protesta no abdicar los derechos imprescriptibles de la soberanía del pueblo a otra persona que a la de su augusto y desgraciado Monarca don Fernando VII, siempre que venga a reinar entre nosotros, quedando por ahora sujeto este nuevo Gobierno a la Superior Junta de Regencia (...) en el momento de esta fatal crisis, porque de la recíproca unión de los americanos y los europeos debe resultar la felicidad pública, protestando que el nuevo Gobierno castigará a los delincuentes conforme a las leyes. (Banco de la República, 1960, pp. 155 ss.).

Como se desprende del Acta de Independencia, los propósitos libertarios criollos no estaban encaminados a erigir una Nación, ni a estatuir una democracia; tampoco a iniciar de manera radical, una ruptura política con el Reino invasor español. Esta proclama del 20 de julio, reconoce la autoridad del Rey Fernando VII, y expresa el sentimiento de solidaridad frente a su desmejorada situación a causa del tirano Napoleón. Hasta se solicita su presencia en estas tierras. Este conglomerado emancipador está integrado por un grupo de blancos privilegiados, criollos que explotaban la mano de obra 
nativa, poseían esclavos y ocupaban algunos cargos en la administración ${ }^{9}$, sin embargo: "Los criollos ricos tienen la propiedad jurídica y la posesión económica colonial y pueden apropiarse de una parte (...) del capital dinero producido allí, pero carecen de la propiedad económica" (Uribe, 1978).

De ahí se desprende como corolario que el contenido del grito de independencia tenía como fin la lucha por la propiedad y la libertad para disponer de ella por parte de los criollos, no se trataba de la lucha por la justicia, dadas las inequidades evidentes y la exclusión y miseria de unos frente a la riqueza de otros: "Remedios se hallaba en el último término de miseria y pobreza, pues apenas había vecino honrado que pudiera contar con lo preciso para manutención y decencia" (López, 1976, p. 31).

Para llevar a término este objetivo criollo era necesario la autonomía del Reino, y para que tuviese la fuerza requerida, era indispensable que se hiciese a nombre del supuesto pueblo. Este proyecto político, en nombre del pueblo pero sin contar con él, entorpece la conformación de la Nación colombiana, como quiera que sigue la quiebra, se radicaliza el fragmentado y heterogéneo archipiélago social y cultural:

...no dio como resultado la formación de un pueblo, de una nación que pretendiera autodeterminación y crear su propio Estado sino, por el contrario, de varios pueblos históricos que los llevaban a plantearse la autonomía política o la fragmentación total en la creación del nuevo Estado" (Uribe, 1978).

ElActa de instalación del Congreso General del Reino del 22 de diciembre de 1810, ratifica esta segmentación del conglomerado social que resultó luego de los procesos de sometimiento de España, dadas las circunstancias es prematuro afirmar que en 1810 se fundó la nación, o siquiera una simiente de una Nación en Colombia.

Colombia en $1810^{10}$ sin lugar a dudas está en con-formación, es pero todavía no, se constituye en una construcción artificial "Colombia: la nación artificial” (König, 1994) "Aunque no falta patriotismo, o cierto fervor por las ideas libertarias por parte de los emancipadores, aún no se define la separación política de España" lo contrahecho o quizá también contrafáctico,

$9 \quad$ Uno de los cargos públicos desempeñados, por las élites criollas era la administración de los Cabildos como estructura social y política colonial.

10 Llamada en este amanecer histórico como el comienzo de la vida patria como boba, la patria boba. 
del carácter de nación, está anidado en el expreso reconocimiento al rey Don Fernando, como cabeza de este Reino, y el reproche al usurpador Napoleón, denota aún las contradicciones, facciones y los intereses en juego de una minoría ilustrada, exclusiva, excluyente:

El Supremo Congreso, por cuya formación anhelaban las provincias y estaba deseosa la capital y los amantes de la Patria y de la felicidad común; que este día, memorable y tan glorioso fastos de nuestra libertad (...) por la señal de la santa Cruz; ¿juráis por Dios Nuestro Señor y los Santos Evangelios que estáis tocando, defender, proteger y conservar nuestra Santa Religión Católica, Apostólica, Romana, sostener los derechos del señor don Fernando VII contra el usurpador de su Corona, Napoleón (...) defender la independencia y soberanía de este Reino. (Restrepo, 1995, p. 18).

No hay respuesta a la pregunta por la unidad de espíritu, de cultura; se advierte que no es viable un Estado-Nación o una Nación es estricto sentido: "ni el país, ni la nación, ni las instituciones sociales estaban preparadas para el movimiento del 20 de julio de 1810 en la ciudad del Nuevo Reino" (López de Mesa, 1970, p. 136).

Así para 1811, continuando con el proceso de construcción y de recomposición de un conglomerado disgregado y aún fraccionado, surgen las influencias de las tendencias libertarias de los ideólogos de la nación como: José Félix de Restrepo interesado en el orden legal, José Camilo Torres centrado en el estamento político, Francisco José de Caldas preocupado por la técnica; Pedro Fermín de Vargas pensando la estructura económica, la educación en cabeza de Francisco Moreno y Escandón, y la figura de Antonio Nariño por antonomasia el revolucionario ${ }^{11}$.

Este dinámico movimiento social de la colonia, trae consigo la creación de juntas independentistas, como expresión de ideas de los modelos democráticos liberales de los Estados nacionales europeos y del esquema norteamericano de organización territorial y política. Para 1811 la Nueva Granada estaba exaltada con los imaginarios de que cada provincia estaba integrada por "individuos libres, iguales e independientes entre sí" (Uribe, 1978 , p. 68), se pensaba como incipiente Nación, pero son lazos que unir, sin subjetividades que reconocer, sin una alteridad que construir: "una red de relaciones de producción fraccionadas y discontinuas que no logran

11 Señala López de Mesa, la contribución de estos pensadores que finalmente son las bases de una cultura colonial colombiana, con intenciones de edificar una futura nación. 
constituir un verdadero sistema económico y que a lo sumo constituyen armazones simples de unidades productivas" López de Mesa, 1970, p. 69). Sin embargo, lejos de las circunstancias en que surgen las creaciones de los Estados nacionales en Europa, irrumpe en la Nueva Granada una formación peculiar, que para 1811, tiene el propósito de apuntalar un sistema federal de gobierno. Este deseo se expresa mediante, el Acta de federación de las Provincias Unidas de la Nueva Granada, 27 de noviembre de 1811.

Acta de federación de las Provincias Unidas de la Nueva Granada, 27 de noviembre de 1811

Esta joven y frágil confederación de naciones se denomina según el Artículo primero de esta Acta, "Provincias Unidas de la Nueva Granada" (Restrepo, 1995, p. 19). Que fuera redactada por Camilo Torres, quien propugnaba por el modelo federativo de Estado-Nación y que llevó a que los delegados de la provincia de Cundinamarca, en cabeza de otro prócer como Antonio Nariño, no firmaron, pues éste estos eran partidarios de un modelo centralista. Esta propuesta de Confederación se asume de manera paradójica, desde la tutela de la religión católica, instalada por la fuerza de la invasión española, y para el siglo XIX, considerada como heredada del Reino Español. Para la coalición era importante que existiera un propósito común explicitado en la ayuda mutua y la defensa del territorio, como quiera que el Reino de España amenazaba con retomar su antigua colonia.

En el nombre de la Santísima Trinidad, Padre, Hijo y Espíritu Santo. Nos, los representantes de las provincias de la Nueva Granada (...) considerando la larga serie de sucesos ocurridos en la península de España, nuestra antigua metrópoli, desde su ocupación por las armas del emperador de los franceses Napoleón Bonaparte; las nuevas y varias formas de gobierno que entre tanto y rápidamente se han sucedido unas a otras, sin que ninguna de ellas haya sido capaz de salvar la nación; (...) dichas provincias, han proclamado sus deseos de unirse a una asociación federativa (...) un solo cuerpo de nación, reserve para cada una de las provincias su libertad, su soberanía y su independencia. (Restrepo, 1995, p. 19).

Este escrito, hace una invitación a todas las provincias, para que se unan a la empresa de proteger el territorio, ante la agresión del antiguo poder invasor, es necesario "salvar la nación” (Restrepo, 1995, p. 19). Determina de manera valiosa para este estudio, el artículo 3 de esta Acta el llamado a la construcción anímica y material de la Confederación, a partir de factores 
como el territorio o cualquier otro vínculo: "ligados con ella por su posición geográfica, por sus relaciones de comercio u otras razones semejantes" (Restrepo, 1995, p. 19).

Añádase que el artículo 4 como signo de convergencia de esta Federación, está centrado en la religión Católica, desde la cual se ha de leer, interpretar y comprender este mundo político y social por venir: "En todas y cada una de las Provincias Unidas de la Nueva Granada se conservará la santa religión católica, apostólica, romana, en toda su pureza e integridad".

Estas Provincias Unidas de Colombia, van crear el escenario de disputas entre los centralistas y federalistas, que consideraban y juzgaban cada uno su postura de gobierno, como el mejor y el más conveniente. Esta división interna se halla reflejada en las firmas de adhesión de las provincias de Antioquia, Neiva, Cartagena, Pamplona y Tunja. Por el contrario las provincias de Cundinamarca y Chocó no rubrican esta Acta.

Bajo esta perspectiva, esta Acta de 27 de noviembre de 1811 pronuncia de manera inquietante pero cierta ese carácter de desunión, como muy particular en el destino de la Nación de Colombia. Formalmente y no en la realidad (como parece ser como se ha edificado esta Nación), esta Acta santifica los ideales del pacto social y la fraternidad entre todos los individuos, como según reza el artículo sexto "Se prometen recíprocamente la más firme amistad y alianza, se juran una fe inviolable y se ligan con un pacto eterno, cuanto permite la miserable condición humana" (Restrepo, 1995, p. 19). Igualmente el artículo 9 invoca el empeño de crear un "solo cuerpo de nación" en donde "concurran al bien universal, haciendo el sacrificio de sus intereses particulares (...) mirando al gran pueblo de la Nueva Granada en todas sus provincias, como amigos, como aliados, como hermanos y como conciudadanos" (Restrepo, 1995, p. 19).

Estos ideales, de convergencia, de construcción de algunos consensos, o lazos del tejido social, en 1811 se ven truncados porque bajo esta Federación de provincias, fallida, se implantó un escenario de guerra, bien contra el enemigo externo español que intentó retomar sus antiguos feudos, bien entre las federaciones por los límites territoriales. De ahí, que la consecuencia que se desprende es que se postergue la solidificación y el nacimiento de la Nación: "La disgregación sociocultural del espacio territorial interno no logra configurar un pueblo histórico que transite hacia la nación, sino varios pueblos históricos que se reconocen en su particularidad y se diferencian a veces agresivamente de los demás" (Uribe, 1978, p. 73). 
Las Provincias Unidas de la Nueva Granada, expresan quizá una de las formas como la futura Nación colombiana se ha de cimentar a través del regionalismo ${ }^{12}$, la radicalidad de las consideraciones identitativas de la región, de la aldeas, de la provincia, del terruño pequeño; o quizá la lectura sea también la lucha por el reconocimiento del pequeño feudo. No a través de unidades de sentido o de procesos históricos y sociales comunes, que lleven a los dinamismos de identificación o al menos a nudos de significado o mentalidades. Para el año de $1815^{13}$, con la retoma del Reino de España ${ }^{14}$, se crea una nueva dimensión en el sentido y el espíritu libertario. La lucha ya tiene un nuevo matiz, lo ideológico y político como reivindicación, tiene una fuerza armada; se crea el ejército libertador.

El resquebrajamiento de estas Provincias integradas en la Nueva Granada, se advierte cuando para el año de 1818 la única libre de la reconquista española era la región de los Llanos, el Casanare. Y es desde allí se reagrupan y determinan las nuevas directivas de la lucha. Esta Declaración de Pore del 18 de diciembre de 1818, expresa para el ejército su proclama de guerra y para la Confederación el escollo para protegerse al menos con el armazón legal, de la retoma de España. Es Francisco de Paula Santander y Omaña, quien es uno de los grandes pensadores y forjadores de la Nación y el Estado Colombiano. Llamado el hombre de las leyes, porque tuvo la tarea de organizar la judicatura y el orden interno. "De buen linaje (...) pero aldeano y pobre, salió de los claustros universitarios a servir plaza de abanderado al iniciarse el movimiento de emancipación nacional" (Restrepo, 1995, p. 39). Se reprocha de su personalidad su falta de generosidad en la aplicación de la justicia. A pesar de ello es quién redacta la Declaración de Pore, desde la legitimidad y la validez otorgada por la Confederación Granadina, en donde expresa en el artículo 1 que "el Estado de Casanare es el único de la Unión que se halla enteramente libre (...) para representar él solo a toda la federación, mientras que libertándose otro u otros estados no entren a participar de la representación nacional” (Restrepo, 1995, p. 39).

\footnotetext{
12 Presente aún en la manera como se expresa el ser colombiano, la geografía humana que centra y despliega la etnia, la raíz, la pertenencia simbólica. El colombiano, es de una región, aún no es de una nación. Cada región emerge como un feudo, unas costumbres, unas sangres, incluso una criminalidad.

13 De 1816 a 1821 se inicia la guerra de las Provincias Unidas contra la agresión externa de España.

14 Se resalta la figura del llamado pacificador Morillo.
} 
Conforme a esta Declaración la confederación tiene unidad en Casanare, la embrionaria nación ahora reside en Casanare:

En la ciudad de Pore a 18 días del mes de diciembre de 1818, reunidos en congreso provincial los representantes del estado libre de Casanare con arreglo a la Constitución federal de la Nueva Granada para acordar y resolver lo que mejor convenga a la salud de la Patria en las desgraciadas circunstancias de hallarse los demás estados de la Unión oprimidos por las armas españolas, cuya dominación injusta, violenta y arbitraria se han comprometido del modo más solemne a repeler, después de varias propuestas y largas discusiones convinieron unánimemente en decretar y decretaron a presencia y bajo los auspicios del Ser Supremo. (Restrepo, 1995, p. 39).

La construcción de la naciente Nación colombiana continúa para el año de 1819, con la presencia imponente y decisiva de Simón Bolívar, con quien se adquiere un eslabón de la arquitectura de Colombia y América. En la Carta de Jamaica el 6 de septiembre de 1815 manifestaba, Bolívar: "Yo deseo, más que otro alguno, ver formar en América la más grande nación del mundo, menos por su extensión y riqueza que por su libertad y gloria (...) pretender formar de todo el mundo nuevo una sola nación" (Universidad Santo Tomas, 1983).

El anhelo de unidad se impone con la Constitución de Venezuela del 15 de agosto de 1819, que estipula la unión de Venezuela y la Nueva Granada, que pese a ser dos pueblos con tradiciones, culturas, etnias, mentalidades, espíritus, ánimos y procesos histórico-sociales diversos, son unificados por la decisión política de Bolívar, que los consolida como un solo pueblo, la historia dará cuenta de las raíces diferentes y distintas de estos conglomerados sociales. En el artículo de esta Constitución 15 manifiesta que: "Venezuela y la Nueva Granada, conforme al voto y al interés de ambos pueblos, (...) los ciudadanos de la Nueva Granada serán ciudadanos de Venezuela por nacimiento, y tendrán opción a todos los empleos, residiendo en su territorio".

Por lo anterior el día 17 de diciembre de 1819, mediante Ley Fundamental de la República de Colombia, dos distintos pueblos quedan unidos bajo el "título glorioso de República de Colombia", como reza el artículo 1; el territorio de la República de Colombia, se conforma según el artículo 2 en una "extensión de 115.000 leguas cuadradas". Conviene señalar que las gestas libertarias han ocasionado grandes compromisos económicos, de ahí 
que gracias a esta unión, las deudas "son reconocidas in solidum por esta Ley como Deuda Nacional de Colombia".

Se desprende de lo anterior que para el año 1919, es precoz y difícil poder comenzar la tarea de ser Nación, confluyen circunstancias desfavorables para su afirmación; estas regiones viven aún la incertidumbre del porvenir, no se vislumbra el arraigo, quizá porque sólo se ha experimentado imposición y desarraigo, la debilidad psíquica para autorreconocerse y reconocer al otro, es manifiesta. El mismo Simón Bolívar reconocía las trabas espirituales identitativas de esta aspiración común, ante el Congreso de Angostura:

Nosotros ni aun conservamos los vestigios de lo que fue en otro tiempo; no somos europeos, no somos indios, sino una especie media entre los aborígenes y los españoles. Americanos por Nacimiento y europeos por derechos, nos hallamos en el conflicto de disputar a los naturales los títulos de posesión, y de mantenernos en el país que nos vio nacer, contra la oposición de los invasores; así nuestro caso es el más extraordinario y complicado. (...) Uncido el pueblo americano al triple yugo de la ignorancia, de la tiranía y del vicio, no hemos podido adquirir, ni saber, ni poder, ni virtud (Universidad Santo Tomas, 1983, p. 73).

La nación Colombiana, es un anhelo, un deseo por lo que pide Bolívar: unidad, unidad; solicita que se yerga el espíritu nacional y que todas las sangres se mezclen. Llega el año de 1821 para intuirse el primer documento de estirpe Constitucional, la Constitución del 30 de agosto de 1821.

\section{La Constitución del 30 de agosto de 1821}

Algunos de los territorios de Venezuela y Panamá ${ }^{15}$ aún estaban en manos de los españoles, sin embargo para proteger los territorios de la amenaza externa de España se debía mantener la unión de las provincias. Irrumpe de este contexto difícil, con la Constitución de 1821, un Estado nacional. Estado nacional con estructura centralista, el ejecutivo en manos de un Presidente, un vicepresidente y sus ministros (Vásquez, 1986, p. 37). La capital del Estado: Bogotá: "El territorio del Estado fue dividido en varios departamentos -que desmembraron las originales tres unidades coloniales: Venezuela, Nueva Granada y Quito-, con unos jefes administrativos, los intendentes, directamente subordinados al presidente" (König, 1994, p.

15 Formaba parte del antiguo Virreinato de la Nueva Granada. 
335). Aquí una nueva fragmentación, de etnia, espíritu, de región, así el colombiano aún no tiene un lugar, donde more el espíritu para hacer historia, para tejer el arraigo de la nación.

La apuesta por el espíritu de unidad nacional, estaba dada en la expresión de realidades culturales históricas y políticas de 3 pueblos diversos. La nación primigenia responde a las necesidades de protección frente a la amenaza que se cierne por parte del Reino Español. La nación comienza su carrera política, esta es la consigna espiritual de esta Constitución de 1821, con los votos de confianza por un Estado nacional común. Una nueva denominación se erige ahora es: República Independiente y Soberana de La Gran Colombia,

Nos los representantes de los pueblos de Colombia, reunidos en Congreso general, cumpliendo con los deseos de nuestros comitentes en orden a fijar las reglas fundamentales de su unión y establecer una forma de Gobierno que les afiance los bienes de su libertad, seguridad, propiedad e igualdad, cuanto es dado a una nación que comienza su carrera política y que todavía lucha por su independencia, ordenamos y acordamos la siguiente Constitución. (Restrepo, 1995, p. 53).

El artículo 1 y 2 de esta Constitución de 1821, establecen que la nación colombiana, en su esencia es soberana y libre del yugo español. Empero esta Nación artificial conlleva las incongruencias y las inconsistencias propias de un conglomerado disgregado, que evidencia de manera clara que no existió La Gran Colombia "Ni antes ni después ese espacio existió siquiera formalmente" (Uribe, 1978, p. 70). Por otro lado el concepto de ciudadano que se introduce como imaginario de unidad, y como expresión de negación de la condición de súbdito del Reino Español, es tan discordante y termina siendo paradigmática, en unos conglomerados en donde están excluidos los negros (porque son esclavos) y los indígenas (porque es el Otro arrasado, negado, la vergüenza) que aún sobreviven. Esta noción se consigna en los artículos 28, 157, 161 y 170, para consagrar valores de participación "Los Ciudadanos que resulten con el mayor número de votos" inherencia de derechos, exigencia de su reclamación, protección y amparo de su intimidad y esfera privada "La libertad que tienen los ciudadanos de reclamar sus derechos ante los depositarios (...) Para que un ciudadano pueda ser preso, se necesita (...) Los papeles particulares de los Ciudadanos, lo mismo que sus correspondencias epistolares son inviolables". 
Recién en 1813 (López de Mesa, 1970) se inicia el proyecto de libertad de los esclavos, liberación que no significa reconocimiento de la condición de ciudadano, porque estos no podrán ser ciudadanos, al igual que los manumisos, los concertados y los indígenas de resguardo (Uribe, 1978, p. 71). Los ciudadanos que integran esta Nación de la Gran Colombia, son aquellas minorías que gozan de los privilegios económicos, los privilegios de la educación, y los privilegios de la libertad, están descritas estas prerrogativas en el artículo 15:

2. Ser Casado o mayor de veinte y un años. (...) 3. Saber leer y escribir (...) 4. Ser dueño de alguna propiedad raíz que alcance al valor libre de cien pesos. Suplirá este defecto el ejercitar algún oficio, profesión, comercio, o industria útil con casa taller abierto sin dependencia de otro, en clase de jornalero o sirviente. (Restrepo, 1995, p. 59).

Se desprende de todo lo anterior, una realidad de fragmentación, división, diáspora, con las consecuentes brechas de exclusión y marginación, detalladas en el texto Constitucional, en donde se favorece de forma notoria los beneficios a las castas criollas, (gestoras de la independencia). Ahora estas clases con el advenimiento de la República, continúan con estas canonjías y termina haciendo del Texto Constitucional un instrumento para gobernarse entre sí mismos, se trata finalmente de continuar lo que reprochaba Sieyès, privilegiados para privilegiados. A causa de ello no se consigue fundar en 1821 una Nación fuerte y consolidada, estas asimetrías la hacen muy frágil e inestable: “Así, la ciudadanía resultó ser una institución tan artificial como la soberanía territorial y ambas constituyeron un semillero de conflictos durante el periodo republicano" (Uribe, 1978, p. 73). La ciudadanía que estipuló la Constitución de la Gran Colombia, terminó creando ciudadanos de primera y de segunda categoría, que en el periodo de 1839 a 1885 desencadenaría cruentas guerras civiles.

\section{Constitución Política de la República de Colombia 5 de mayo de 1830}

Las dificultades internas, socavan los cimientos de la Constitución de 1821, las tensiones son evidentes y el regionalismo endémico, se exacerba por el centralismo marcado de la Constitución de 1821, por otro lado la crisis es mayor dados los deseos de separación de Venezuela y Ecuador de la Gran Colombia. La muerte de Simón Bolívar en 1830 es el punto de inflexión de la disolución dirá Miguel Antonio Caro: “es como la ruina del 
sagrado Ilión, el desencanto de nuestra historia, que de fabulosa se torna en prosaica (...) es la historia de nuestra desgraciada familia, nuestra propia historia contemporánea" (Vásquez, 1986, p. 59). Esta Constitución nace paralela a la Constitución de Valencia, que implanta la división del Estado Venezolano en cabeza del general Páez y finalmente el Estado del Sur del Ecuador se aparta bajo el mando del general Flores.

Las condiciones descritas no permitieron engendrar una Nación, ni siquiera este conjunto disgregado logró identificar o al menos hacer el esfuerzo por crear lazos espirituales y culturales en torno a sentimientos emancipadores o libertarios por tener un invasor común. Ni un enemigo común genero unidad, ni causa común "La Constitución de 1830 no tuvo los efectos esperados de reanimar y mantener la unidad de la República de Colombia, establecida en 1819. Más aún para algunos nació muerta”. (Vásquez, 1986, p. 78). Establecía la Constitución moribunda de 1830, en el artículo 1 que la Nación colombiana estaba unida bajo un mismo pacto político, que era soberana y que esta soberanía estaba radicada en el pueblo. La paradoja era que no había pueblo, ni Nación para constituir dadas las desintegraciones, divisiones y los intereses tanto internos como externos.

A nivel interno la Nueva Granada se debatía en agrias y violentas disputas entre liberales y conservadores: "La escisión entre liberales y conservadores fue cada vez más nítida y los enfrentamientos para defender sus proyectos constitucionales fueron cada vez más violentos" (BasilienGainche, 2008 junio). Y a nivel externo el conflicto estaba trabado con los problemas divisionistas de venezolanos y ecuatorianos, de ahí que resulta inconsecuente, sin validez material invocar la unidad y armonía de los pueblos en la Carta Magna: "En el nombre de Dios, supremo legislador del universo. Nosotros los Representantes de Colombia, reunidos en Congreso, en uso de los poderes que hemos recibido de los pueblos para constituirla" (Restrepo, 1995, p. 101).

Las intenciones de crear una Nación en Colombia, hasta 1830 se han malogrado y la oportunidad de haber emergido como una gran Nación, con un enemigo invasor común ha quedado sepultada; así un enemigo externo común no fue suficiente. Los regionalismos como enemigo interno rebasaron y sobrepasaron la voluntad de unión y las aspiraciones de identidad suramericana. La existencia institucional de la Nueva Granada como un Estado Nación independiente, surge con la figura del Presidente General Francisco de Paula Santander y Omaña y se instaura con la Constitución política del Estado de la nueva granada del 1 de marzo de 1832. 
Constitución política del Estado de la nueva granada del 1 de marzo de 1832

El año de 1832, significa para este conglomerado social colombiano, un abanico de vicisitudes que van más allá de la búsqueda de un patriotismo exacerbado. La Nueva Granada tiene sus saldos en rojo, la deuda pública interna y externa era alta, como debía suponerse luego de las batallas independentistas; sus fronteras indeterminadas estaban solo resguardadas por las disposiciones jurídicas emanadas de los documentos constitucionales de la Gran Colombia, así lo evidencia el artículo 2 "mismos que en mil ochocientos diez dividían el territorio de la Nueva Granada de las capitanías generales de Venezuela y Guatemala, y de las posesiones portuguesas del Brasil: por la parte meridional (...) al sur de la provincia de Pasto" (Pineda, 1997, p. 141)

Quienes integraban este Estado, recibían a partir de 1832 la denominación de granadinos: "Su población no alcanzaba los dos millones de habitantes" (Vásquez, 1986, p. 81) Era una Nación libre y soberana pero solo formalmente, pues sus referentes ideológico, políticos y sociales seguían siendo el Reino Español; internamente aún le faltaba a ésta la afirmación de auténticos derechos civiles inclusivos, la iniquidad eran patente tanto que aún existían en el Estado esclavos. La ciudadanía según el Artículo 8 no era una condición ni una calidad para todos, sólo para los granadinos casados o mayores de veintiún años, que supieran leer y escribir y ante todo "Tener una subsistencia asegurada, sin sujeción a otro en calidad de sirviente doméstico, o de jornalero" (Restrepo, 1995, p. 148). A causa de las inequidades, exenciones, menosprecio y desigualdades e injusticias persistentes, se trata de un Estado con tendencia liberal, pero frágil aún en ciernes, que no logra convocar, ni tejer los hilos de una nación para hacer apuestas sociales.

La Nación Granadina aún debe esperar para su configuración, identidad y estructuración, los vaivenes históricos, culturales y los momentos aciagos no son lo propicios para su construcción. ¿Cómo autoreferenciarse como granadino, si los que otrora eran Colombianos ahora no son? no hay forma de reconocer qué es un Granadino, la Nación no se crea por una Norma Fundamental, faltan los procesos, el espíritu, las mentalidades "Dicho reconocimiento, es una experiencia identitaria mediada a través de signossímbolos" (Bolívar, 2001, p. 10). 
A partir del año 1839 se inician periodos de guerras civiles generales, que desmiembran al Estado Nación Granadino "La Nueva Granada, apenas establecidos los poderes públicos, entraba en el vórtice infernal de la violencia y la guerra santa de los partidos" (Restrepo, 1995). Dichas guerras se suceden entre periodos de 1839 a 1841, en 1851, entre 1859 a 1863 , entre el 1876 y el 1885, el epicentro de estos estallidos bélicos fue la provincia de Santander, dicha provincia llegó a sumar 12 Constituciones, con la condición de ser fronteriza con la antigua Capitanía de Venezuela

\section{Constitución de la República de la Nueva Granada de 8 de mayo 1843}

El clima de crisis, y conflicto social y político para el año de 1843 crea la necesidad de reformar la Constitución de 1832, como quiera que esta Carta contiene disposiciones que "presentan graves inconvenientes en la práctica, y que acerca de otras se han originado dudas por el modo con que están expresadas; por lo que ha venido a ser indispensable reformar unas, añadir o suprimir otras" (Restrepo, 1995, p. 189). Esta Carta de 1843 tiene otra intención, constituir y darle fuerza a la figura del presidente y con ello, intentar resolver los problemas sociales que vivía la Nueva Granada. Esta Constitución es centralista, de tinte conservador, eleva a rango constitucional el carácter Católico, Apostólico y Romano de la Nación, como se consagra en el artículo 16 "La religión Católica, Apostólica, Romana, es la única cuyo culto sostiene y mantiene la República" (Restrepo, 1995, p. 193)

De la edificación del concepto de Nación la Constitución de 1843 aporta poco, quizá el sentido y sentimiento religioso como impronta común, aunque heredada del Estado invasor; se mantiene la ciudadanía según el artículo 9 en cabeza de:

Los granadinos varones $(\ldots)$ de veintiún años (...) dueño de bienes raíces situados en la Nueva Granada que alcancen al valor libre de trescientos pesos o tener una renta anual de ciento cincuenta pesos; y pagar las contribuciones directas establecidas por la ley, correspondientes a dichos bienes o renta (...) Saber leer y escribir. (Restrepo, 1995, p. 191).

Con esto reseñado se reitera la deuda frente a la consolidación de la Nación que para el año 1843, era integrada por varones, católicos letrados y con renta, excluyendo por lo tanto a mujeres, pobres, iletrados, siervos, jornaleros y esclavos (que aún permanecían en esta condición). Los hilos de la Nación no podían tejerse aún por las brechas injustas. 


\section{Constitución de la República de Nueva Granada de mayo 20 de 1853}

Marca esta nueva Constitución, la presencia de un personaje fundamental en la historia de la Nación Colombiana Tomás Cipriano de Mosquera "Para sus amigos, mascachochas (...) Gran General Tomás Cipriano de Mosquera y Arboleda (...) cuatro veces presidente de la República (...) de la masonería, militar, terrateniente, comerciante (...) su estímulo del progreso nacional, su clara visión de la Gran Colombia” (López de Mesa, 1970, p. 166). Para 1845 era nombrado presidente, configurando un panorama progresista del Estado.

Su sucesor José María Obando "El drama de Obando consistirá cabalmente en ser llevado por la multitud que lo aclama como el conductor de una revolución política, cuando él quiere ser, tan solo, el Jefe de Estado" (Vásquez, 1986, p. 102), es el blanco en contra del cual se establece la Constitución de 1853, con la que inicia la Nueva Granada las sendas del Estado débil. De esta constitución han señalado insignes hombres como Miguel Antonio Caro, que era anárquica, y José María Samper la refirió como "la más funesta de cuantas había tenido la república, porque con ella se abrieron todos los caminos de la guerra social y la anarquía" (Basilien-Gainche, 2008 junio). Sin embargo la pretensión de esta Carta Magna fue la de consolidar una Nación Estado, liberal consagrado en el artículo 1 "República democrática, libre, soberana, independiente de toda potencia, autoridad o dominación extranjera" (Restrepo, 1995, p. 226) . El gobierno definido para este descentralizado Estado, era el instaurado por el artículo 10 en tanto "popular, representativo, alternativo y responsable". La primigenia Nación, ahora liberal estatuía al ciudadano para que eligiera a sus gobernantes, regionales o de provincias, otorgando amplitud y autonomía en sus decisiones. También el ciudadano partícipe era protegido en sus libertades, especialmente en el libre pensamiento (artículo 5 numeral 7).

El proyecto de Nación, o la aspiración de su consolidación, en 1853 en tanto liberal representativa, es novedosa para un ciudadano que se estrena en la participación y las libertades, pero que nuevamente se enfrenta a los ideales formales de la Carta, con el caos y el desorden causado por la creación de los Estados Federales Soberanos de: Antioquia, Santander, Cauca, Cundinamarca, Boyacá, Bolívar y Magdalena, todos alentados y afirmados por el habitual regionalismo. Vale la pregunta ¿A qué Nación se puede pertenecer, cuándo hay fragmentación y separación? Cómo poder construir redes comunes, cuando se estrechan las regiones. De esta manera se aplaza la cimentación de la Nación colombiana, conformada sólo por 
"Ciudadanos varones granadinos que sean, o hayan sido casados, o que sean mayores de veintiún años”. (Restrepo, 1995, p. 228).

En 1851 con el gobierno de José Hilario López se abolió la esclavitud, pero ello no significó que ocuparan los liberados un lugar en la vida nacional, ni siquiera en la simbología nacional o en la "iconografía republicana (...) Sin duda, las élites criollas temían el poder de los pardos" (Pineda, 1997).

Constitución para la Confederación Granadina del 22 de mayo de 1858

La Nueva Granada para el año de 1858, ya había pasado por un golpe de Estado en 1854, y desde 1855 el panorama es el mismo disgregación y disolvencia: "Que en consecuencia de las variaciones hechas en la organización política de la Nueva Granada (...) han constituido en ella ocho Estados federales, son necesarias disposiciones constitucionales que determinen con precisión y claridad las atribuciones del Gobierno general" (Pineda, 1997, p. 263). De esta manera el recorrido de esta indagación, en la segunda mitad del siglo XIX, da cuenta de que no había una sola Nación, sino que existía un mosaico de Naciones Soberanas, con Constituciones, formas de gobierno y varias tendencias entre conservadoras, radicales y liberales. El caos bien podría definir este periodo constitucional de la historia de Colombia, se constituye en un intento de Nueva Nación, que según el artículo 1 se denomina ahora como "Confederación Granadina" que se autodefine como "Soberana, libre e independiente". La anarquía expresa en este Texto Constitucional, tiene ribetes dramáticos, que definitivamente hacen que el intento de construir una Nación sea un fracaso. Los Granadinos de esta Confederación tienen la aspiración de fundar la Patria, acentúan la libertad absoluta de prensa y el porte libre de armas, y como corolario de esta catástrofe, es necesario reseñar la propuesta vergonzosa de Florentino Gonzáles de incorporar ¡esta Confederación a la Unión Americanaj. Una incipiente y confundida nación, cuya respuesta es de negación rotunda a tamaño despropósito por parte de la prensa de los Estados Unidos, para quienes Colombia era (sin duda) una Nación débil, y era impensable, para la Unión Europea fotos de los "Representantes y Senadores tostados por el sol” (Vásquez, 1986, p. 136).

Constitución Política de los Estados Unidos de Colombia del 8 de mayo de 1863

La figura central en este escenario constitucional, y en donde no se asienta aún una nación, es Tomás Cipriano de Mosquera, quien es: "amo de una 
Nación desprovista de instituciones". La Constitución de 1863 brota en medio de la confusión que surca la Nación desde 1858, este texto trae un nuevo nombre para los Granadinos, que según el artículo 1 ha de ser "Estados Unidos de Colombia" (Restrepo, 1995, p. 303). Si la nación aún no tiene nombre, no es simbólicamente cargada, entonces es oscura su conformación.

Establece esta Carta que los ciudadanos de los Estados Federados, según el artículo 91 podían tomar las armas y recibir el tratamiento de beligerantes, además contaban también con la protección a no ser considerado como traidor; ni mucho menos a que sean procesados por el delito político, como quiera que estaban bajo el amparo del Derecho de Gentes que hacia parte del Texto Magno "Atentar contra las autoridades legítimas era entonces un simple error de cálculo que bien podía no ser victorioso sin acarrear consecuencias penales de ninguna naturaleza" (Vásquez, 1986, p. 161). Este opaco panorama con un nuevo nombre para la nación, es una traba fuerte, para poder siquiera de manera incipiente sentar las bases de un conglomerado con algún tipo de ligazón, sólo existe por doquier divisiones y digresiones en los Estados Soberanos. No hay nación, a lo sumo regiones, intereses, grupos luchando entre sí, sin una ruta o mínimos de consensos para conseguir unidad, identidad.

\section{Constitución Politica de la República de Colombia de agosto 5 de 1886}

La desinstitucionalización que vive el país ya para los finales del siglo XIX, era tal que el orden o la prevalencia social y política, lo decidía quien tuviese el poder de las armas, la situación de postración económica era mayúscula fruto de los enfrentamientos y del desgaste de los conflictos internos. La guerra de 1885 había asestado el golpe final a la Nación y a sus instituciones. Por lo anterior el contexto de devastación permite que de las tensiones y la postración surja una Constitución como la de 1886, marcada por un Estado fuerte, con clara tendencia centralista, y con descentralización administrativa.

La figura ideológica es Miguel Antonio Caro, quien el 17 de mayo de 1886 decía: "La resurrección de la patria exige proclamar la Soberanía Nacional, de modo que "ya no hay soberanos coexistentes" (Sáchica, p. 30). La figura política es el presidente Rafael Núñez, de tendencia neoliberal quien enarbola los derechos individuales dentro de los límites que imponen el orden general. En 1885 señala el presidente Núñez: "El curso de los acontecimientos ha destruido el régimen constitucional, productor de permanente discordia, en que hemos agonizado, más que vivido, durante 
un cuarto de siglo" (Sáchica, p. 193). Surge entonces una nueva Nación, fuerte centralista y (abandonando el centralismo de los Estados Soberanos, como uno de los principios políticos de esta Constitución, señala Luis Carlos Sáchica, se encuentra la negación del nombre Soberanía, unido al modelo republicano, centrándose en la denominación de República, como tendencia dentro de un Estado Democrático Nacional (Sáchica, p. 18)) unitaria: "En nombre de Dios, fuente suprema de toda autoridad (...) Y con el fin de afianzar la unidad nacional y asegurar los bienes de la justica, la libertad y la paz" (Restrepo, 1995, p. 344). Establece el artículo 1 que a partir del 5 de agosto de 1886 Colombia es una república unitaria, y advierte el artículo 2 que la soberanía "reside esencial y exclusivamente en la Nación, y de ella emanan los poderes públicos." (Restrepo, 1995, p. 344). Este deseo de conservación de la unidad y el orden en una sociedad como la de 1886 que evocaba la provincia, la colonia: "era una sociedad cerrada, enclaustrada, aislada como la colonial” (Sáchica, p. 155) se expresa en el propósito de la disposición moral de las creencias y los ánimos de los ciudadanos, toda vez que la religión católica, se consagra como la justificación del naciente Estado Nación y en la fuente primaria de cohesión y legitimidad de la acción estatal:

La iglesia Católica podrá libremente en Colombia administrar sus asuntos interiores y ejercer actos de autoridad espiritual y de jurisdicción eclesiástica, sin necesidad de autorización del Poder civil; y como persona jurídica, representada en cada Diócesis por el respectivo legitimo Prelado, podrá igualmente ejercer actos civiles, por derecho propio que la presente Constitución le reconoce. (Restrepo, 1995, p. 353)

Conviene señalar que la Constitución de 1886, tiene por ciudadano a los varones colombianos, mayores de 21 años, que realicen una profesión, arte $\mathrm{u}$ oficio, es decir que tengan un medio de subsistencia; dejando de lado a las mujeres, los negros, los indígenas y los millares de desposeídos y pobres como herencia adquirida desde 1810 hasta los Estados Soberanos, sigue la ciudadanía aristocrática, nobiliaria "la verdad, el hecho que salta a la vista, es que no hubo movimiento especial alguno respecto a la repartición de los grandes feudos territoriales, y antes bien, según entiendo, la República recompensó a algunos de sus próceres con amplias concesiones territoriales" (López, 1976, p. 41). El Estado conservador fuerte, incluso puede suspender la ciudadanía a los viciosos como el caso de la "beodez habitual" (artículo 17 numeral 3, como garante de las buenas costumbres y el alejamiento de los desenfrenos. El presidente se constituye en la figura central para esta huérfana y opaca Nación, ávida de un monarca, que para el caso no tendrá 
corona pero si mando: "Una República monárquica, si se permite la paradoja, o una Monarquía republicana" (Vásquez, 1986, p. 196).

De 1810 a 1886, queda Colombia en deuda, en cuanto a la construcción de la Nación, los quiebres históricos, sociales, culturales, políticos han dejado en suspenso el tejido de los lazos sociales, el reconocimiento de la identidad, de lo propio y la aceptación de ser mestizos, como un novedoso modo de pensarse, existir y ser. Hasta este final del siglo XIX, aún no hay nación consolidada, a lo sumo regiones afincadas, aún provincianas, con los rezagos de la exclusión, el desconocimiento, la pobreza, la injusticia y la inequidad social. Está es una identidad fragmentada, dividida, enferma, sin arraigo simbólico, y muy cercana a las fronteras de la psicosis general.

\section{Constitución Política de la República de Colombia de 1991}

El siglo XX llega y con él una nación embrionaria, difícil, problemática, paradójica y por el peso del conflicto paradigmática. Los movimientos abiertos y la crisis de los metarrelatos de la posmodernidad "Simplificando al máximo, se tiene por $<<$ postmoderno $>>$ la incredulidad con respecto a los metarrelatos. Ésta es, sin duda, un efecto del progreso de las ciencias; pero ese progreso, a su vez, la presupone" (Lyotard, 2000, p. 10), introduce en el pensamiento de este proyecto de Nación Colombia, la discusión acerca de quiénes han integrado este pueblo. Por primera vez se plantea la cuestión fundamental de la identidad que viene anudada a las preguntas como ¿qué es un colombiano, qué define a un Colombiano, existe un espíritu y una mentalidad común colombianos? "La identidad se cuenta, la nación existe en cuanto se hace relato. Somos como las historias que nos representa y reconocen" (Rincón, 2001, p. 7). Las posibilidades de respuesta iniciaron

a comienzo del siglo XX, cuando las concepciones sobre la eugenesia y la decadencia de las razas, llegaron a concluir "firmemente en la decadencia de nuestra raza (...) Todavía a mediados de los treinta, algunos autores mantuvieron la idea de que, como consecuencia de la mezcla de indios y negros, la raza colombiana se había degenerado completamente" (Pineda, 1997, p. 113). En la década de 1940 surgen nuevas intencionalidades y autoreferencias acerca del pensar la Nación Colombiana, entre la que se destaca el ser una Patria Mestiza, ya no como un oprobio sino como parte y ser de las entrañas mismas y la necesidad de este auto reconocimiento para construir un proyecto de Nación. 
Sin embargo para los años de 1960 y 1970, vive el país las luchas por las reivindicaciones campesinas e indígenas, quienes buscan ser visibilizados y reconocidos. Estas demandas logran la enseñanza bilingüe para las comunidades indígenas (Decreto 1142 de 1978) y la constitución de grandes resguardos indígenas. Las comunidades negras o afrodescendientes no lograron generar un amplio movimiento nacional, sin embargo estaban presentes en la agenda nacional. (Pineda, 1997, p. 115)

El contexto en que surge la Constitución de 1991 frente al espíritu nacional es que este aún está fraccionado por regiones y no se participa íntegramente del autoreconocimiento de una Nación común. Además persiste la ausencia constitucional de los negros e indígenas para el Estado Colombiano, quienes hasta 1991 no tenían estatus, representatividad ni dignidad constitucional.

La constitución de 1991 se erige por una Constituyente "de minorías en busca de espacio político y de garantías protectoras del territorio conquistado" (Sáchica, 1996, p. 105) como herramienta política para restaurar la paz, (fruto de la violencia multicausal), pretender la reconciliación nacional y modernizar el Estado, reza el preámbulo: "el fin de fortalecer la unidad de la Nación y asegurar a sus integrantes la vida, la convivencia, el trabajo, la justicia, la igualdad, el conocimiento, la libertad y la paz" (Colombia, 1998). Un nuevo Estado se instituye: el Estado Social de Derecho "Colombia es un Estado social de derecho, organizado en forma de República unitaria, descentralizada, con autonomía de sus entidades territoriales, democrática, participativa y pluralista" ${ }^{16}$ que ampara un número significativo de derechos fundamentales (artículos 11 a 41), en el que el artículo 13 es el "núcleo axiológico de la Constitución" (Sáchica, 1996, p. 104) además derechos sociales económicos y culturales (artículos 42 a 77) como también derechos colectivos y del ambiente (artículos 78 a 82). Como Estado Social de Derecho y como Nación Pluralista, esta carta Magna consagra diversos preceptos de autoreconocimiento vital y esencial, por primera vez desde 1810 se instituye la presencia, el derecho y la existencia de Otros que no son los criollos de las gestas emancipatorios, ni los colonos y republicanos para quienes "la República de Colombia debía ser construida sobre la base de la sangre y cultura española (heredada de la madre patria) y la cultura francesa" (Pineda, 1997, p. 113). Esta Carta ahora pluralista funda un Estado que "reconoce y protege la diversidad étnica y cultural de la Nación colombiana"17 erige la obligación de "proteger las riquezas

\footnotetext{
16 artículo 1, el resaltado es para señalar este especialísimo carácter pluralista.

17 Consagrado en el Artículo 7 de la Constitución Nacional.
} 
culturales y naturales de la Nación"18. Como lengua oficial, la Nación tiene el castellano, pero también "Las lenguas y dialectos de los grupos étnicos" 19 . Y se ha de señalar como de especial relevancia el artículo 171 que confiere representación política propia a los grupos indígenas en el Senado, pero no así para las comunidades afrodescendientes que debieron esperar a la Ley 70 de 1993 para ser reconocidos como comunidad étnica y con participación.

El proyecto de Nación que surge de la Constitución de 1991, en tanto pluralista plantea el gran reto de hallar los lazos, los hilos sociales, los procesos históricos y culturales que puedan dar cuenta de lo que es la Nación Colombiana. Vale la pena resaltar como hecho significativo por el peso de lo simbólico y la representación social que quien es invocado, como poder soberano es el Pueblo no la Nación. Quizá con la intención de recuperar el sentido de esa auténtica Nación la de los sufrimientos, las divisiones, los ideales por hacer y cumplir; el Pueblo, la Nación que es necesario curar de tantos males padecidos. Por lo tanto sanar la Nación, el pueblo colombiano se hará desde las mentalidades, los tonos espirituales de la Nación en tanto mestiza. Tendrá que vislumbrar e intentar construir en la marcha, en las vicisitudes propias de un conglomerado que no da cuenta por su pasado, que no tiene tanta claridad frente al rol de la ley, y cuya pobreza monetaria, para el siglo XXI es del $29.3 \%$ y el de pobreza extrema es del $8.4 \%$, (DANE, 2015) que pesan y definen el alma nacional que exige ser curada.

El reto de construir la nación colombiana, está en la superación de regionalismos, y poder tejer hilos de consensos, solidaridad, reconocimiento de todos los actores sociales, que integran lo que podría ser una nación, con un nombre, unas etnias, pluralistas, y con apuestas ideológicas por terminar el conflicto armado, que parece endémico, porque siempre ha estado presente, sólo han mutados las iconografías, los contextos y los propósitos. Esta nación en construcción debe hallar en el orden social, en el compromiso civil ciudadano, los lazos étnicos, espirituales; la nación ha de ser expresión y despliegue de alteridad, inclusión, reconocimiento, más allá del orden jurídico, se trata de una reformulación cultural, ideológica, se sentido y comprensiones de la realidad colectiva que también hace y centra como un cardo al individuo, que es y pertenece a una nación.

\footnotetext{
18 Establecido en el artículo 8 de la Constitución Nacional.

19 Instituido en el artículo10 de la Constitución Nacional.
} 


\section{CONCLUSIONES}

La Nación colombiana difícilmente se pudo configurar desde la irrupción violenta de España, en el siglo XVI, y de manera consecuente en los procesos de pacificación y colonia vividos en los siglos XVII, XVIII, no fue posible tejer los hilos históricos sociales y espirituales del sentir de una Nación.

Los esfuerzos emancipatorios del siglo XIX, no contribuyeron por los escenarios de fragmentación y disgregación a la fundación del sentido anímico de la Nación. Son cinco las fuentes filosóficas e históricas (López de Mesa, p. 161) que incidieron en la configuración de las Cartas Magnas en Colombia, y que fueron dibujando y dando color a la posibilidad de creación de la Nación colombiana, son estas los derechos del hombre, la Constitución de Filadelfia, El catolicismo, elementos de la cultura grecoromana, y la legislación española.

El siglo XXI y los albores del XXI, se configuran en un reto para la conformación de la Nación colombiana, es la apuesta de una sociedad por los ideales reales y auténticos de la libertad, igualdad y justicia para todos. La Nación aún es proyecto está por hacerse, es un compromiso de todos: "acelerar el proceso formador de la nación, es decir educar y capacitar al pueblo para hacerlo sujeto efectivo del poder político, autogobernante, autodeterminado, pues si la sociedad no es democrática sus instituciones políticas tampoco pueden serlo. (Sáchica, p. 89)

La nación debe ser sanada de sus heridas, sus desaciertos y las condiciones asimétricas que la hacen aún frágil y sin clara representación. De tantos nombres recibidos desde el siglo XVI hasta hoy, el nombre de este Pueblo de Colombia debe ser enunciado, asumido y querido como propio para así lograr forjar identidad y prever un destino común próspero para todos.

\section{BIBLIOGRAFÍA}

Banco de la República .(1960). Publicaciones conmemorativas del Sesquicentenario de la Independencia Nacional. Bogotá: Banco de la República .

Basilien-Gainche, M.-L. (2008 junio). La consttucionalidad de contienda: La promoción juridica de la guerra civil en la Colombia del siglo XIX. Historia Crítica, 130-149.

Bolívar, I. E. (2001). Cuadernos de Nación, Belelza, Fütbol y Religiosidad Popular. Bogotá, D.C.: Ministerio de Cultura. 
Botella, et al, J. (1998). El pensamiento politico en sus textos. Madrid: Tecnos S.A. Colombia, R. d. (1998). Constitución Politica de Colombia. Santafé de Bogotá: Imprenta Nacional de Colombia.

Hauriou, A. (1980). Derecho Constitucional e Instituciones Políticas. Barcelona: Ariel. Hesse, Conrado. (2001). "Constitución y Derecho Constitucional”. En: B. e. al, Manual de Derecho Constitucional. Madrid: Marcial Pons.

König, H. J. (1994). En el Camino hacia la nación: nacionalismo en el proceso de formación del Estado y de la nación de la Nueva Granada. Bogotá: Banco de la República .

López, A. (1976). Problemas Colombianos. Medellín: La Carreta.

López de Mesa, L. (1970). Escrutinio sociológico de la historia Colombiana. Medellín: Bedout.

López de Mesa, L. (s.f.). De como se ha formado la Nacion Colombiana. Medellín: Bedout S.A.

MESEP. (2 de Septiembre de 2009). Pobreza monetaria en Colombia: Nueva metodología y cifras 2002-2010. Recuperado el 20 de 2 de 2012, de www.banrep. gov.co: http://www.banrep.gov.co/documentos/conferencias/Medellin/2011/ presentaci\%F3n\%20Pobreza\%20Monetaria\%20en\%20Colombia\%20\%20 Carlos_Eduardo_Velez.pdf

Moreno, P. \& Melo, J. (2010). Caminos Reales de Colombia. Bogotá: Banco de la República .

Naranjo, V. (2003). Teoría Constitucional e Instituciones Políticas. Bogotá: Temis S.A.

Pineda, R. (1997). La Constitución de 1991 y la perspectiva del multiculturalismo en Colombia. Alteridades, 107-129.

Pombo, G. (1986). Constituciones de Colombia. Bogotá: Biblioteca Banco Popular.

Restrepo, C. (1995). Constituciones Políticas Nacionales de Colombia. Bogotá: Universidad Externado de Colombia .

Rincón, O. (2001). Cuadernos de Nación. Relatos y memorias leves de nación. Bogotá D.C.: Ministerio de Cultura.

Sabine, G. (2002). Historia de la teoría política. México: Fondo de Cultura Económica .

Sáchica, L. (1962). Constitucionalismo Colombiano Historia Teoría y realidad del Sistema. Bogotá: Temis.

Sáchica, L. C. (1986). La de 1886, una Constitución a la Medida. Bogotá: Temis.

Sáchica, L. C. (1996). Nuevo Constitucionalismo. SantaFe de Bogotá: Temis.

Sáchica, L. C. (2002). Constitucionalismo Mestizo. México: Universidad Autónoma de México. 
Salazar, R. (1984). Filosofía de la Pacificación en Colombia. Bogotá: El Búho.

Salazar, R. (1994). Filosofía de la Conquista en Colombia. Santafé de Bogotá. D.C.: El Buho.

Sieyès, E. (1973). ¿Qué es el Tercer Estado? Ensayo sobre los privilegios. Madrid: Alianza.

Silva, F. (2000). Introducción a la Antropología Jurídica. Lima: Universidad de Lima .

Universidad Santo Tomas. (1983). Bolívar ante el Derecho. Bogotá: Universidad Santo Tomás.

Uribe, M. (1978). Poderes y regiones: Colombia, 1810-1850. Bogotá: Universidad de Antioquia .

Vásquez, A. (1986). El poder presidencial en Colombia. Bogotá: Suramérica LTDA.

Zabalza, J. (1992). La filosofía Colonial ¿Nuestra tardia edad media? Santa fé de Bogotá, D.C.: El Búho. 


\section{MIGUEL ANTONIO CARO \\ Y LA CONSTRUCCIÓN HISTÓRICA \\ DEL CONCEPTO DE PERSONA ${ }^{1}$}

\section{David VALencia Villamizar ${ }^{2}$}

\section{Capítulo Uno}

\section{EL SIGLO XIX COLOMBIANO Y LA REGENERACIÓN}

Haciendo un breve balance historiográfico del siglo XIX colombiano, este capítulo presentará críticamente, diversas imágenes que desde la economía, pero también desde la historia social o la ciencia política se han fabricado sobre este período. Comenzando por la consideración del último Germán Colmenares acerca del carácter narrativo del conocimiento histórico, en partícular examinando las convenciones a través de las cuales se modeliza un relato de los acontecimientos. Enseguida la construcción de la Nación y el llamado "nacionalismo cosmopolita" será el horizonte sobre el que se harán apreciaciones sobre el territorio, la economía y los dispositivos normalizantes que se desplegaron durante la regeneración con el objetivo, siempre elusivo, de cimentar la Identidad colectiva de las Personas.

1. EL CUENTO DE UN PROTOCOLIZADO PASADO

\section{Germán Colmenares y las “convenciones” del tramado histórico}

La memoria es un ordenado conjunto de interpretaciones que posibilita la coherencia necesaria para configurar una identidad estable. El problema de

$1 \quad$ Este capítulo es resultado del proyecto de la linea de de investigación "Historia, Cultura y Derecho" denominado Construcción Histórica de la Nación Colombiana adscrito al Centro de Investigación de la Facultad de Derecho de la Universidad Santo Tomás.

2 Abogado Universidad Nacional, Magister y Doctor en Historia de la misma Universidad, profesor e investigador universidad Santo Tomás, e-mail: davidvalencia@ usantotomas.edu.co. 
constituir un registro de datos y utilizarlo como referente de lo acontecido es fundamental para pensar la idea de nación en los territorios liberados de la corona española a comienzos del siglo XIX. Sobretodo cuando la pretensión es desnudar el mecanismo que alumbra una determinada versión de la Historia colombiana en éste período.

German Colmenares (1987) presenta una mirada del quehacer del historiador del siglo XIX como agente configurador de esa memoria histórica absolutamente indispensable en el proyecto de construir una autonomía política y económica en los espacios geográficos recién independizados. El interés primordial del historiador es constatar las condiciones de aparecimiento de esas "historias patrias", al analizar lo que él denomina "convenciones", como aquellas directrices que provenían de Europa y que determinaron el tipo de historia que se escribiría en América.

Según Colmenares operaría un desfase entre esos moldes de legibilidad y la cultura tal como efectivamente se presentaba en las colonias españolas.

Se hace un recorrido por debates como el entablado entre Bello y su discípulo Lastarria para discernir el tipo de enfoque que se le estaba dando a la construcción de un pasado común. Es claro que la tensión se presentaba entre aquellos que querían hacer tabula rasa de la herencia colonial y quienes todavía se articulaban alrededor de esos horizontes.

La historia es el cuento de lo que una nación ha sido, un relato construido según las preferencias epistemológicas del autor y que hace comprensible lo que ya no existe: la evanescencia connatural del acontecimiento se ha venido sosteniendo en este trabajo es apresada en unas rejillas lingüísticas que funcionan como una plantilla discursiva que urde una memoria al elaborarla. Se traman los eventos en un orden preciso, se engendra el sentimiento de que esa visión es lo efectivamente acontecido y con ese golpe de verosimilitud (efecto de realidad para Roland Barthes) se cristaliza la ilusión de una entidad inmutable: la identidad cultural de un pueblo.

Así las cosas, el intento de Germán Colmenares se cierne sobre el tipo de ensamblaje enunciativo que permitió la consolidación de un pasado heroico, mítico, épico y glorioso que daría la lugar a la sensación de individuación requerida para que cada Nación se considerase autónoma e independiente.

Por ello mismo, la secuencia de hechos que llevó a un Miguel Antonio Caro, ultra-montano, conservador, excluido, objeto de censura etc. a ser vicepresidente encargado de la presidencia (1892-1898), es posible leerla 
según los apuntes precedentes. Ubicados en el contexto de los regímenes radicales que, como se trabajará en el capítulo correspondiente, impulsaron una serie de reformas económicas, que para muchos constituyeron el verdadero punto de quiebre frente a una legislación colonial en buena parte vigente aún después de la independencia. Resulta muy llamativo que la denominada "Regeneración" haya surgido justo como reacción a las políticas federalistas y librecambistas de estos gobiernos a mediados del siglo XIX.

Un aspecto central, a este respecto, es la idea de que la "independencia" no se logró sino hasta que principios caros a la ideología liberal-democrática fueron efectivamente puestos en práctica: la fundación de los partidos liberal y conservador a mediados de siglo, así como un primer y audaz intento de secularizar la estructura del Estado estuvieron en el centro de la controversia política de la época, particularmente sensible durante el gobierno del General Tomás Cipriano de Mosquera.

En líneas generales, los discursos de los liberales en el poder, tradicionalmente divididos en draconianos y gólgotas, según el grado de radicalidad en la aplicación a ultranza de los principios de liberalización de la economía, considerados adalides del "progreso" y la "civilización" como rejillas conceptuales que arman discursivamente la percepción de los eventos, giraban alrededor de la idea de emular administrativamente, respecto del sistema político, a naciones como Gran Bretaña o Estados Unidos de América. Por ello esta protocolozación/mitificación del pasado fue encauzada, en la historiografía liberal, como una lucha contra las retardatarias y clericales fuerzas de la reacción, caricaturizadas como defensoras de un modo de vida tradicional, que requería urgentemente ser reemplazado por relaciones sociales propias de una capitalismo industrial.

Sabemos además, gracias a las Convenciones que Germán Colmenares ha puesto en evidencia, que las endémicas guerras civiles, entre facciones cuyos ideales parecían claramente diferenciados, pero que finalmente acababan ambas cohonestando un proyecto único de hegemonía políticoeconómico, desmovilizó y sofocó el surgimiento de partidos realmente clasistas, donde estuvieran representadas las mayorías explotadas por una estructura hacendataria aún presa de condiciones de producción precapitalistas. Desde esta óptica puede entenderse la sanción de más de once constituciones en el siglo XIX, lo que refleja por un lado la inestabilidad institucional, pero también la forma de aparentar un "respeto a la legalidad" y la "normalidad jurídica" cada vez que una guerra civil era ganada por alguno de los bandos fratricidas. 
Este cuento, con poderosos "efectos de realidad" que es el pasado protocolizado en una lista de fechas memorables e hilvanadas teleológicamente, se parece mucho a la manera como, en el mismo siglo XIX, se escribían las narraciones literarias en Europa. El costumbrismo en nuestro medio sirvió como estructura estructurante para una heterogeneidad cultural no abordable por otros medios. Hacer legible la experiencia de lo real, tornar comprensible lo que fuimos para situar lo somos y proyectar lo que llegaremos a ser es la tarea más importante de la Historia como molde de subjetivación de quienes se hallan así congregados. También la Historia se constituye en proceso de objetivación de la realidad; la manera como se aglomeran singularidades en la idea socialmente compartida del mundo.

Colmenares, a quien seguimos en la tentativa de descifrar los códigos estéticos y gnoseológicos sobre los que se inscriben los acontecimientos, aborda la fabricación de una temporalidad intra-discursiva que vendría a sustituir la percepción directa de lo que ya se ha escapado en un irrecuperable pasado. Pasando por vectores de temporalización como el calendario, la invocación generacional o el manejo de fuentes se logra visibilizar ése "dispositivo de manufacturación de la temporalidad" que finalmente será el que domine la naturalización de experiencias cronológicas ajenas al presente desde donde se mira lo acontecido. En Colombia este dispositivo funcionó elaborando la idea de una Soberanía Nacional desmembrada por el federalismo de la constitución de 1858, pero sobretodo galvanizado a partir de la Constitución de Rionegro de 1863, gracias a la habilidosa carrera de un dirigente liberal como Rafael Núñez, quien estratégicamente se alió a los conservadores para conformar el "Partido Nacional" que le daría la victoria en las urnas a la fórmula Núñez-Caro en las elecciones presidenciales de 1892.

En esta narración, los factores económicos tuvieron gran relevancia, la emisión descontrolada del "papel moneda" por los Bancos de los Estados confederados, en ausencia de una política monetaria centralizada, devaluó considerablemente el peso, ocasionando un caos económico oportunamente aprovechado por los porta-estandartes de movimiento regenerador.

El héroe también funge de piedra de toque como perspectiva de imantación de lo ocurrido. La figura de Rafael Núñez en tanto líder carismático y aglutinador simbólico de los "sentimientos colectivos" operó como un elemento importante a la hora de explicar la transición del radicalismo hacia el largo período (hasta 1930) de "hegemonía conservadora". 
Comparar esta narrativa con la tejida, en otras partes del continente, en autores como José Manuel Restrepo, Bartolomé Mitre o Gabriel René Moreno enseña que no puede hablarse en el continente americano de la preponderancia de un estilo único, sino del vertimiento personal de las elecciones metodológicas de cada autor. En lugar de ubicar un rasgo integrador de las historias escritas en el siglo XIX en Suramérica, encontramos distintas concepciones del mundo generando cosmovisiones divergentes que serán las encargadas de dar claridad al devenir presente de éstas naciones.

Una vez más, el relato histórico está teñido de sangre; la última guerra civil, antes de la sanción de la longeva constitución de 1886 lo demuestra; nuevamente liberales y conservadores, enfrentados por factores que giraban simbólicamente alrededor de la preponderancia de la Iglesia Católica, tomada como baluarte de la Identidad colombiana, o considerada un estorbo la pujante y anticlerical mentalidad "moderna" en nuestro país, animó un debate que, de acuerdo a la óptica enunciativa, se desarrolló como una "cortina de humo" para la consolidación de un proyecto de élite, o en realidad confrontó dos visiones antagónicas sobre la naciente República colombiana.

Nuestro autor aprovechó inteligentemente la victoria militar, iconizada en la famosa frase "la constitución de 1863 ha dejado de existir", atribuida a Nuñéz luego de la batalla de la "Humareda". De tal forma que Miguel Antonio Caro, impulsando un proyecto de corte hispanofílico, se hizo con el sillón presidencial, desde el cual, como veremos en el desarrollo de este escrito, tuvo la oportunidad como pocos, pero ante a la oposición contumaz y férrea de los liberales ahora excluidos del manejo de Estado, de implementar sus políticas educativas. Se reestablecieron las relaciones con la Santa Sede en un concordato que en 1887 devolvió el control de la educación a la Iglesia Católica, en una jugada ideológicamente inteligente, dándole contenido a la noción de Persona que correspondía con el proyecto hegemónico que estaba siendo desplegado, diseñando un molde de subjetividad específico, con miras a robustecer la plataforma mental de la Regeneración conservadora en Colombia.

Este catálogo narrativo de artificiales verdades que es la Historia puede desmontarse para mostrar el mecanismo de su agenciamiento discursivo. Colmenares logra ponernos en el camino de esa estrategia desmitificante pero a mi parecer falla al considerar las convenciones narrativas como algo opuesto a la cultura concreta de un pueblo. La hipótesis central de Las 
convenciones contra la cultura (1987) es precisamente esa, el antagonismo presente entre unos cánones de racionalidad que serían inapropiados para pensar la cultura de los países americanos. Creo que esas convenciones no van contra la cultura, sino que son la cultura. Esas convenciones estéticas son la textura de la realidad, la fabrican al distribuirla en paquetes de sentido plausible; la cultura será el productor producido en la interacción recíproca con esos esquemas de pensamiento. Las convenciones hacen la cultura; no podemos entenderla como algo independiente de las motivaciones relatológicas que le han dado origen, que han modelado en un cuento asumible la incesante complejidad del caos pre-discursivo.

\section{LA PARADOJA DE LA NACIÓN}

\section{Lo que está adentro (Colombia) es el afuera (Europa textualizada)}

El nacionalismo cosmopolita es un concepto contradictorio. Si algo es nacionalista no puede simultáneamente aludir al cosmopolitismo, entendido como ausencia de nacionalismo. Ser cosmopolita es habitar como patria cualquier patria, asumir como propia cualquier nación del mundo. Entonces, a partir de esa paradoja podemos decir que el texto de Frédéric Martínez (2001) emprende un análisis de las condiciones paradójicas de nacionalización de la identidad en la segunda mitad del siglo XIX en Colombia. Lo que nos permite estudiar los fundamentos de la ideología de la Regeneración.

El "yo" (el nombre propio, la nacionalidad) se construye a partir de una diferenciación frente a "lo otro". La identidad se elabora a partir de las diferencias con un entorno, con un exterior que ha quedado separado, aislándose un territorio para ejercer la soberanía. En éste caso, ese entorno es Europa, y la noción de un "afuera" como referente ineludible es aquí la del continente europeo. Pero lo que está encerrado es el afuera; lo que está adentro es el afuera y por eso en lo más interior de la nación lo que hay es un colcha de retazos ajenos, pedazos de los discursos del "otro", el horizonte de occidentalización civilizatoria brindado por los países de Europa occidental, la Cosmópolis imponente.

Se habrían presentado tres momentos en el definitivamente inacabado proceso de consolidación de la nación colombiana (siglo XIX). El primero tiene que ver con el llamado neoborbonismo del gobierno de Mosquera, el 
segundo sería la fase más radical del liberalismo y el tercero, en el gozne del siglo, el proyecto de la Regeneración.

Sobre esa cuadrícula Martínez ofrece un fecundo estudio de la forma como fue "textualizado" el continente Europeo al imaginarlo, al contarlo, al ser relatado por los viajeros que desde Santander habían iniciado un periplo por el viejo mundo. Queda claro que se trató en todo caso de la apreciación de un modelo de organización política para la naciente república colombiana.

Existiría una máquina retórica funcionando como matriz de surgimiento de los discursos generadores de identidad. Esto es especialmente claro durante el período de la Regeneración. Cuando se unificó gramaticalmente al país, el verbo operó performativamente como aglutinante enunciativo de la nación. El orden del discurso es el orden público, la corrección al hablar es la corrección del comportamiento; así las cosas, el incesante proceso de identificación en Colombia estaría atravesado por la manera como en los debates políticos era vista Europa en sus bondades y en sus desdichas.

Si el acto de mirar necesariamente implica un efecto de perspectiva (no hay perspectivas absolutas), entonces es ese sesgo al considerar el arquetipo de Europa el se esquematizará amañadamente según los intereses que quieran prevalecer. Por eso las referencias a la Cosmópolis; son siempre equívocas, se hace una mixtura donde Inglaterra, Alemania, Francia y España aparecen deformadas por el ángulo de enunciación empleado al considerarlas. Se fabrican conjunciones insólitas donde lo que prepondera es el contraste entre la facilidad con que las polémicas son nutridas por esas visiones y la enorme dificultad de plasmar esos postulados en un aparato institucional propio. Es esa distancia la que hace que la crítica a la imitación de los paradigmas foráneos sea en realidad una crítica a la perspectiva asumida, no al hecho de utilizarla.

Lo cierto es que ese grado de alteración discursiva frente a lo Europeo está mediado por factores políticos y económicos innegables. Desde los relatos de viajes como el ya clásico De sobremesa de José Asunción Silva, se puede apreciar la forma como se demoniza o se idealiza la referencia a "lo otro", la situación cultural y social de las naciones "avanzadas", su desbarajuste político o su ejemplo recomendable.

Transitando por la heterogeneidad de enfoques (el papel de la Iglesia, el sistema de educación, el régimen de propiedad, etc.) que confluyeron a lo largo del siglo XIX en la confección de lo propio según se diferencia de lo 
ajeno, el nacionalismo cosmopolita muestra toda una serie de antinomias cuya solución en la praxis política apenas logra ocultar las inconciliables contradicciones que apareja la idea de "nación" como algo autónomo frente a referencias exógenas.

Porque lo que está en juego es el destino histórico de un pueblo donde tal vez el único rasgo común es la desobediencia, la falta de autoridad, el desmoronamiento institucional, la ausencia de Estado.

Producto de interiorizar esas exterioridades - amenazantes o bonachonasla nación colombiana se presenta como un proyecto incesante, permanentemente acechado de paradojas.

3. LA REGENERACIÓN Y LOS DISPOSITIVOS NORMALIZANTES

Partiendo de un marco conceptual proporcionado por la sicología como modelo comprensivo del comportamiento de los individuos, Fernando Guillén Martínez (1986) plantea entender las relaciones sociales en Colombia a finales del siglo XIX .

Así las cosas, Guillén en el texto La Regeneración, primer frente nacional; se propone dilucidar los mecanismos de integración social según el esquema de la Hacienda como un sistema integrador que normalizaría los comportamientos socialmente pertinentes, adscribiéndolos a modos de conducta económicamente explotables.

Configurando una verdadera red de "sistemas proyectivos", éstas estructuras estructurantes (ejemplificados en la disciplina hacendataria) funcionarían en el dominio de lo simbólico, generando patrones de percepción y acción socialmente permisibles. Se trataría de un dispositivo de dominación que, en manos de las élites dirigentes, se encargaría de cohesionar a los individuos según un régimen de jerarquías y una ideología políticamente manejable. Es así como se entienden los partidos políticos en el marco general de las anteriores afirmaciones. Los partidos políticos en Colombia operarían más como un subterfugio de las clases dirigentes para mantener la conformidad necesaria en la implementación de un particular proyecto hegemónico. En vez de constituirse las colectividades partidistas en el campo de expresión de antagonismos económicos, lo que ocurre es la reproducción de un sistema de exacción donde, a través del manejo de clientelas afiliadas y lealtades seudo-lógicas, se perpetúan unas condiciones específicas de sujeción. Vale decir, a partir de la segunda mitad del siglo 
XIX el nacimiento de los partidos liberal y conservador no tiene nada que ver con una consciencia de clase que buscaría exteriorizarse en el debate político; lo que tenemos es dos bandos bastante similares haciendo el papel de reclutadores de fidelidades que finalmente vienen a asegurar el modelo económico en uso.

Sobre ésta base es que se explican las guerras civiles del siglo XIX en Colombia: se trataba de un artificio para consolidar el sentimiento de pertenencia necesario en la galvanización de las relaciones de poder existentes. Cuando aflojaba el grado de adscripción debido a problemas económicos y tecnológicos era necesaria una guerra para afianzar los lazos así distensionados; una vez logrado esto, se procedía a través de coaliciones (La Regeneración) en el intento de ofrecer un panorama favorable a la inversión extranjera y una situación que hiciera posible el comercio exterior tan Caro al sistema capitalista en ascenso.

En suma, se trata de mostrar cómo la polémica anticlericalismo/ clericalismo usualmente asociada con la Regeneración no es sino el disfraz que cubre la necesidad de reorganizar las condiciones de dominación que económicamente se habían hecho insostenibles después de la caída en las exportaciones de quina, añil y tabaco. Se entiende que el periodo del federalismo había contado con el auge del proyecto agro-exportador, lo cual había hecho posible la constitución de Estados regionales funcionando como dominios de hegemonía particulares administrados por los hacendados (excepto el caso de Antioquia), y gamonales terratenientes en vías de convertirse en industriales capitalistas. Destruidas las condiciones internacionales que posibilitaban el establecimiento de los gobiernos federales, se hizo necesaria la implementación de un proyecto político, que tras la fachada de una ideología católica y moralizante, lo que garantizó fue el reacomodamiento de las jerarquías en un nuevo sistema económico necesitado de una Banca central para el manejo hegeónicamente satisfactorio de las clases menos favorecidas-.

La disputa entre partidos no era tal en tanto el mismo Rafael Núñez o José María Samper (para citar solo las figuras paradigmáticas) en el ala liberal habían virado hacía una concepción del Estado más central y autoritaria. Se necesitaban luchas intestinas que, según una lógica de odios exacerbados y una pugnacidad de carácter intransigente, sirvieran de plataforma para la coalición que representó la Regeneración en la última parte del siglo XIX.

El conflicto entre "razón" y "fanatismo" o entre "anarquía" y "autoridad" no es sino una égida bajo la cual tanto el partido liberal como el conservador 
buscaban salvaguardar sus privilegios económicos en un nuevo régimen ajustado al orden económico mundial. La Iglesia católica y el "alma del concordato" -como la llama Guillén Martínez- no era solamente una concesión de poder al clero, sino que, a través de la entrega de la educación a la Iglesia, se lograba implementar un mecanismo de control social tan necesario para una masa de nuevos proletarios cuyos vínculos morales se habían desdibujado en las migraciones del campo a la ciudad. La Iglesia se subordinó a las reformas administrativas de las élites gobernantes y no al revés; fueron éstas las que reformularon las lealtades de base en una configuración estatal centralizada, el "poder cimero", a través de una nueva clase de empresarios emprendía la tarea de acoplarse a la economía mundial según se replantearan las condiciones sociales mínimas para el ejercicio de la dominación. Modulando las expectativas de los individuos en sistemas integradores patriarcalistas, verticales y disciplinados: el dispositivo de la Hacienda remozado en prácticas simbólicas que lo dotaban de viabilidad al normalizar el comportamiento de las clases subalternas.

\section{LA CONFECCIÓN HISTÓRICO- GEOGRÁFICA DE LA NACIÓN}

Resulta fundamental el reconocimiento del espacio sobre el cual un Estado va a ejercer su soberanía, la constatación de su territorio, la ponderación de sus recursos naturales, la medición de sus distancias y el desvelamiento de las costumbres de su pueblo. De eso se encargó la comisión corográfica que inició labores durante el gobierno de Tomás Cipriano de Mosquera en la Nueva Granada (1850).

Es evidente que un factor clave en la construcción de la nación es su territorio. Una vez terminadas las gestas independentistas aparecía ineludiblemente la tarea de aglutinar un referente de identidad para los Estados recientemente configurados. Intereses políticos hacían inexorable la elaboración de una cartografía del país según los postulados de las Ciencias dominantes en Europa occidental. Económicamente era indispensable saber las riquezas de las que disponía la Nueva Granada en el diseño de las rutas comerciales más favorables para su explotación y circulación. A éstos factores debemos añadir el propiamente científico, que encabezado por Francisco José de Caldas, había señalado la enorme importancia que tienen los conocimientos geográficos para un pueblo en desarrollo, una nacionalidad en germen que debía someterse al espíritu ilustrado que 
determinaría un grado de desarrollo material y de bienestar común para todos los habitantes del territorio.

Efraín Sánchez (1999) emprende un sesudo estudio de la comisión corográfica, enfatizando los condicionamientos políticos y económicos de su surgimiento. De tal suerte se aquilata la gigantesca trascendencia del espacio como escenario sobre el que serán desplegadas las actuaciones históricas a todo lo largo del siglo XIX en Colombia.

La verdad es que las directrices cientifizantes de la teoría cartográfica brillantemente representadas en la figura de Agustín Codazzi- hicieron que La Nueva Granada emprendiera el ambagioso camino de auto-percepción como nación en un contexto absolutamente dependiente de las reglas del método científico y de la lógica de la práctica diagramática, cartográfica dimanante de Europa en los siglos XVIII y XIX.

Nadie dudaba de las bondades de un conocimiento racional del territorio patrio, establecido como necesidad casi desde el momento mismo de la independencia. Sánchez nos muestra la serie de avatares por los que tuvo que pasar el proyecto de una geografía económica hasta consolidarse en los viajes de Codazzi, Ancízar y toda la pléyade de eminencias que protagonizaron la expedición corográfica.

Efraín Sánchez va a presentar una biografía muy documentada de Agustín Codazzi, señalando cómo la genialidad cartográfica y militar del personaje lo convirtieron en epónimo de una época de racionalismo floreciente e iluminado. Por otra parte es claro que el empeño civilizador de la comisión se vio acompañado por una exaltación de lo autóctono, la construcción de una imagen bucólica, de unos paisajes de ensueño que funcionaron como núcleos de cristalización de la incipiente identidad nacional. No en menor proporción lo hicieron los relatos literarios de esos periplos, tanto Manuel Ancízar con su peregrinación del Alfa como Santiago López tejieron una urdimbre narrativa capaz de forjar sentimientos de pertenencia con relación a un terruño idealizado por sus descripciones.

La metodología de Codazzi se mostraba acorde con las prescripciones y normativas que la ciencia geográfica dictaminaba para el momento. Desde la expedición botánica de José Celestino Mutis a finales del siglo XVIII hasta la comisión corográfica se fueron refinando los criterios de clasificación botánica, por ejemplo, lo cual hacía más plausible la universalización de las taxinomias vegetales halladas en el Nuevo Reino. Además de la perspectiva 
visual asumida para representar las especies según los requerimientos Linneanos estaba la tentativa de utilizar las categorías de pensamiento racional en cualquier aproximación a lo autóctono. Para legibilizar la realidad de la Nueva Granada se implementaron procedimientos de lectura foráneos. En el campo de la geografía, las leyes de perspectivización, los criterios proyectivos, la articulación en escalas, los íconos de simbolización fueron todos tomados de afuera: para la comprensión y delimitación de territorio como espacio íntimo y soberano de la nación se interiorizaron marcos conceptuales de un hegemonizante racionalismo europeo.

Las consecuencias económicas de la comisión corográfica hicieron que ese saber local logrado mediante la observación atenta a lo cotidiano, a través de una aparente neutralidad al basarse en evidencia empírica, se instrumentara en una lógica capitalista que bien pronto determinaría que el país se insertara en el mercado mundial como proveedor de materias primas en clara sumisión a los países industrializados encargados de procesarlas. Políticamente se usaría un discurso montado sobre el referente de una corografía esclarecida para hilvanar la sensación de autonomía y unicidad que tanto necesitaban las élites dirigentes para consolidar su proyecto de dominación.

La forma de mirar crea el objeto observado; la actitud ilustrada y luminiscente de Codazzi y sus condiscípulos haría que se percibiera la realidad nacional de una manera en particular y no de otra, teniendo como consecuencia importante que Colombia quedara sujeta a un marco referencial racionalista. Una cartografía que privilegia los focos de producción sobre otros aspectos tenidos por anodinos, el ensamblaje de una imagen de sí idealizada, la traducción de una complejidad humana, espacial en un catálogo de topónimos manejables, manipulables según las reglas de un modelo de Estado liberal incrustado en procesos de circulación de capital cada vez más mundializados, bajo una mirada científica que legitimaría esas prácticas hegemónicas, haciendo plausible la emergencia de un mapa dado por descontado, un código de (de)ciframiento y una mirada clasificatoria tenida por incuestionable, un sistema de aprehensión de los acontecimientos que, desde la comisión corográfica hasta nuestros días, ha marcado nuestro destino histórico como país fracturado.

Contextualizando estas afirmaciones, es posible sostener que la unión temporal que, a nivel geográfico, se experimentó en nuestro territorio, durante la primera y segunda década del siglo XIX parece que se generó a partir de "solidaridades" de guerra, más que en el sentimiento de unidad 
del pueblo colombiano. En el primer momento de construcción nacional, lo que mantuvo atada a la Nueva Granada fue un sentimiento que representaba una política "contundente" hacia la formación del Estado:

"Es lógico que las mencionadas provincias abogaran por una unión laxa, por un Estado federal para la Nueva Granada, según el ideal y modelo de los Estado Unidos, admirado por muchos granadinos. De esta forma, en noviembre de 1811, las más importantes provincias de la Nueva Granada se asociaron en la confederación de las Provincias Unidas de la Nueva Granada. Dentro de dichas confederación las distintas provincias promulgaron sus propias constituciones: Tunja en diciembre de 1811, Antioquia en mayo de 1812 y nuevamente en junio de 1815, Cartagena en junio de 1812, Mariquita y Neiva en junio de 1815. En tanto, la confederación no proclamó constitución alguna, pese a diversos esfuerzos y declaraciones fundamentales que regían las competencias del gobierno federal. (...)Las provincias de Santa Marta en la costa caribe y Pasto, al sur, no se asociaron a ninguno de los bloques, sino que permanecieron fieles a España y la Corona. Las diputas entre centralistas y federalistas con sus respectivos representantes Antonio Nariño en Bogotá y Camilo Torres en Popayán, alcanzaron proporciones de guerra civil entre 1812 y 1815; sólo hasta diciembre de 1814 pasó Cundinamarca a formar parte de la confederación, más o menos forzosamente tras la derrota que sufriera frente a las tropas de las Provincias Unidas comandadas por Simón Bolívar. Estos enfrentamientos debilitaron a la Nueva Granada en los aspectos militar, político y social facilitando así la Reconquista por parte de las tropas españolas en el ano de 1816 bajo el mando del general Pablo Morillo" (Konig, 1994:191).

En el segundo momento de la independencia, entre 1819 y 1830 (aunque las aspiraciones son diferentes) se establece un proceso de unidad que converge también entorno a la guerra. "La aspiración de libertad y su disposición de luchar conjuntamente contra el poder colonial unió momentáneamente a todos los americanos, fueran venezolanos, neogranadinos o ecuatorianos" (Konig, 1994:395). Los tres territorios respondían a lógicas administrativas y sociales que se hallaban bastante distanciadas por el devenir histórico. La Capitanía de Venezuela y la Presidencia de Quito eran "regiones que originalmente habían pertenecido, por algún tiempo, a la unidad administrativa colonial del Virreinato de la Nueva Granada, pero que ya en el período colonial español se habían convertido en unidades administrativas relativamente autónomas y habían llevado a cabo, cada una por su cuenta, 
su movimiento independentista" (Konig, 1994:331). "El espacio territorial, al cual pomposamente la Constitución de 1821 "República Independiente y soberana de la Gran Colombia "constituyó una heterogeneidad que sólo existió formalmente durante el periodo de la Independencia: fue ante todo el espacio de la guerra, el espacio articulado en torno a la sucesión de batallas y administraciones provisorias que el ejército libertador iba dejando a su paso" (Uribe, 1987:71). Este era un espacio que no se forjó entorno a la consolidación de un mercado nacional clásico que integrara el territorio que recorrió la gesta libertadora; las divergencias económicas, sociales y étnicas hacían de la consolidación de la conciencia nacional grancolombiana un anhelo plasmado en la Constitución. "La disolución de la Gran Colombia en 1830, apenas sellada la Independencia, pone de presente la fragilidad de ese "espacio de guerra" como unidad territorial; ni siquiera las unidades político y/o administrativas en que se dividió la República o la asamblea constituyente de 1832 [después de la separación de Ecuador en 1831] lograron constituir unidades económicas y/o políticas, se trata de poderes locales enfrentados violentamente por el control de las regiones o pueblos históricos, así como por la dominación del recién nacido aparato estatal" (Uribe, 1987:71).

5 . EL DISCURSO DE LA IDENTIDAD ENTRE LA FRAGMENTACIÓN Y EL CONSENSO

El problema que estudia Alfonso Múnera (1998) en El fracaso de la nación es precisamente el de la (no)construcción de la identidad nacional en el territorio que hoy día es Colombia. Analizando el período comprendido entre 1717 (fecha en que se intentó por vez primera el establecimiento del virreinato de la Nueva Granada) y 1810, el autor cartagenero se propone destruir tres mitos que a su juicio han reinado impasibles en la historiografía colombiana desde 1827 (cuando aparece la Historia de la Revolución de la República de Colombia de José Manuel Restrepo) hasta nuestros días.

Desde una revisión historiográfica Múnera constata que la perspectiva de una comunidad de intereses en la élite criolla de finales de siglo XVIII se da como un presupuesto indiscutible; otro tanto ocurre con la idea de una nueva Granada políticamente unida. Presuposiciones estas a las que se suma la de una clase indígena y mulata intrascendente o favorable a los españoles durante el proceso de independencia. 
Desmitologizar esas premisas es entonces la empresa que se acomete en el texto que nos ocupa. Para lograrlo, el autor recurre a una serie de argumentos encaminados a demostrar las condiciones de fragmentación que caracterizaban a la nueva Granada del siglo XVIII. Deconstruir un referente que sigue haciendo parte del sentido común de los historiadores no es cosa sencilla, y por eso Alfonso Múnera sostiene sus hipótesis según un ensamblaje discursivo muy cuidadoso con las fuentes y bastante metódico en la hilvanación de las conclusiones.

Básicamente se trata de mostrar las condiciones de aislamiento regional al que habían sido condenadas las distintas provincias en un régimen colonial despótico e incoherente. Por incoherencia entendemos políticas institucionales pensadas desde la metrópoli como un remedio al decadente estado de las economías del Nuevo Reino pero que finalmente lograron el efecto contrario: consolidar un paisaje de miseria donde la integración de las ciudades era una utopía dadas las condiciones geográficas por una parte, y la desidia administrativa por otra.

En ese entorno difícilmente podría hablarse de una pre-identidad nacional; más bien (siguiendo siempre el eslabonamiento causal de Múnera) hallamos una atomización regional marcada por la prevalencia de intereses económicos de las emergentes élites comerciantes que a la larga daría al traste con cualquier discurso integrador en el plano político.

El caso de Cartagena muestra el antagonismo entre la floreciente clase dominante de esa ciudad y la rivalidad surgida con su homóloga de Santa Fé, para deducir de esa fricción el enfrentamiento que llevaría al naufragio de la idea de nación durante el período de la "patria boba" (1810-1815). Presentado un panorama decadente (relajación moral, pestilencia, atraso cultural) en la costa caribe, el autor afirma que la cristalización de una economía urgida de libres transacciones fue el factor decisivo contra las anquilosantes políticas de la corona española. Lo que viene a significar que, debido al férreo manejo que desde España se le daba a los asuntos de las colonias ultramarinas, se generó un clima de escasez y descontento que posibilitó el advenimiento de una clase comercial pujante y crítica respecto de las orientaciones mercantiles del Imperio de los Borbones. En un trasfondo de lucha económica por el control de la hegemonía comercial del Nuevo Reino entre Cartagena y Santa Fé era impensable el surgimiento de unos rasgos comunes entre las dos provincias. Si, a finales del siglo XVIII, en lugar de un virreinato congregado alrededor de un horizonte compartido 
culturalmente encontramos un régimen quebrado entre disputas por la creación de un consulado de comercio (y los subsiguientes avatares sobre la función asignada a éste de construir una vía de comunicación entre la costa y el altiplano), entonces no es descabellado hacer una lectura de los restantes acontecimientos históricos (primera declaración de la independencia, patria boba, reconquista española) desde ésta perspectiva.

Así las cosas, se reconfigura el papel usualmente asignado a los mulatos de la costa Caribe en la independencia, trasladando la tesis de una participación pasiva a un protagonismo en el logro de garantías tendientes a la igualdad política para una clase tradicionalmente objeto de explotación y marginamiento.

Se apunta hacia una crítica de los relatos que ven en el concepto de nación un proceso homogéneo, o que le otorgan a los cartageneros el rol de enemigos de la causa nacionalista, cegados por ese "genio del mal" que afantasmaba la imaginación de José Manuel Restrepo. Dada la confección ordenada de unos razonamientos apoyados tanto en documentos de la época como en el cotejo de textos sobre la materia, la visión de Múnera resulta verosímil a la luz de su propio arsenal probatorio. Personalmente creo que el discurso de la identidad nacional resulta más plausible sobre un fondo desgarrado y económicamente convulso, que apoyado sobre figuras románticas acerca de la unidad y fraternidad de grupos culturales heterogéneos. Deshacer el sentido natural y obvio de las narraciones sobre la identidad colombiana se muestra como un fecundo ángulo de análisis en una contemporaneidad indudablemente heredera de una historia de contorsiones más que de un fábula de consensos.

6.

EL RÉGIMEN ECONÓMICO EN COLOMBIA DURANTE EL SIGLO XIX

La economía colombiana durante el siglo XIX estuvo caracterizada por el interminable intento de insertarse en los patrones de la economía mundial. Desde el punto de vista de Salomón Kalmanovitz (2003) el surgimiento de la República estuvo marcado por un déficit fiscal enorme, producto de las deudas adquiridas para financiar la guerra de independencia; así las cosas, desde un inicio las formas de producción coloniales habrían determinado una deficiencia en la manera de sobrepasar estructuras pre-capitalistas de producción. 
Se ha dicho que solo hasta mediados de siglo con las reformas liberales podría hablarse de una superación del aparatoso régimen colonial en la Nueva Granada; lo cierto es que a pesar de que el clima intelectual del siglo XIX estaba dominado por las filosofías liberales, en la práctica la mentalidad religiosa y hasta cierto punto feudal de la mayoría de la población hacía inviable la consolidación de un Estado liberal en éstos territorios.

Señala Jorge Orlando Melo (1989) que hacer una historia económica en Colombia tropieza con el serio inconveniente de no contar con estadísticas confiables. La dispersión de los datos o su apuntamiento sesgado harían muy complicado establecer con certeza las bases empíricas y cuantitativas imprescindibles para emprender un análisis económico. Autores como Mac Greevey (1979) harán una lectura enfatizando la agudeza del déficit fiscal, en tanto que el mismo Jorge Orlando Melo puede matizar sus conclusiones al interpretar de otra manera la insuficiencia de los datos disponibles. En medio de esa incertidumbre es claro que factores como el marcado regionalismo, la ausencia de medios de comunicación idóneos desde el punto de vista de la agilidad capitalista, la presencia de unas relaciones de servilismo que desde lo religioso marcaban una sujeción incondicional al terrateniente y hacendado, pero sobre todo, la baja productividad derivada de un estancamiento en los flujos de capital caracterizaron las prácticas económicas a lo largo del siglo XIX.

De esos factores cabe destacar la persistencia de un sistema esclavista en las grandes haciendas del Cauca y el sur del país. La tan prometida libertad no había sido otra cosa que un artilugio para perpetuar un estado de sumisión ahora en manos de la élite criolla. La inserción en una economía mundial se vería entonces marcada por las directrices del imperio Inglés, que además de cobrar sus empréstitos, harían del librecambio la nueva religión de los intelectuales americanos. El utilitarismo, la fe desmedida en las bondades de la civilización, el progreso con arreglo a las leyes del libre mercado, fueron principios dados por descontados en el diseño de políticas públicas de organización económica en la recién constituida República. Es por ello que puede hablarse de una división mundial del trabajo en donde, según las invisibles pero inexorables leyes de la lógica del capitalismo industrial, le correspondía al país convertirse en exportador de materias primas que serían procesadas por los países más desarrollados. Con ésta idea en mente los gobiernos de Colombia trazaron un camino dirigido a robustecer el proyecto agro-exportador que escasamente con el auge tabacalero de la segunda mitad del siglo, lograría encontrar alguna realización en la praxis. 
Es interesante constatar que el modelo económico colonial resistiría casi hasta finales de siglo XIX - con el cultivo del café- a los embates de una ideología liberal que ya había manifestado su problematicidad con el conflicto entre proteccionistas (artesanos) y librecambistas a mediados de siglo. Es necesario aclarar que el país se convirtió en exportador de ciertos productos de muy variable desempeño en los mercados internacionales; el caso de la quina es un ejemplo de la fragilidad de un sistema exportador basado en productos sujetos a incesantes fluctuaciones con respecto a los precios y a las condiciones de su explotación y comercialización a nivel mundial. En ese sentido el tabaco sería una efímera tabla de salvación que perduraría en tanto las formas de producción fueran competitivas, pero que una vez demostraran su atraso harían que fracasara el modelo que los radicales habían logrado institucionalizar en la forma de una liberalización general de la economía, plasmada en la reducción de tasas arancelarias, y en el paulatino desmonte de las políticas intervencionistas del Estado centralizado.

Zozobrado el modelo liberal con la brusca caída de las exportaciones tabacaleras, no hay otro remedio que girar hacia un Estado centralizado y económicamente controlador, que con una banca central dirigiera efectivamente la economía y garantizara las condiciones mínimas de crédito que requerían los exportadores. El milagro aparece en un occidente antioqueño que había progresivamente salido de las relaciones serviles de producción, pasando de una gran hacienda semi-esclavista a unidades productivas familiares donde la lógica de la acumulación era más propicia. Fue en Antioquia donde se desarrollarían los primeros albores de un capitalismo competitivo a través del cultivo del grano de café (Ocampo, 1989).

Me parece clave entender que esto solo pudo suceder cuando se modernizaron las relaciones de jerarquía y surgió una incipiente clase burguesa capaz de jalonar procesos de producción acordes con las velocidades de circulación del capital dominantes en la Europa de la época. El mercado mundial cambiaría sus hábitos de consumo haciendo del café un estimulante sumamente apetecido en una realidad cada vez más acelerada, requiriente de un aumento productivo donde la cafeína proporcionaba el estado anímico necesario para la los febriles ritmos de trabajo imperantes. Es esa coyuntura la que hace que, por primera vez, se hable de una inserción en la economía mundial, a través de un solo producto que habría generado la constitución de un mercado interno y de unas condiciones (medios de transporte, infraestructura en general) favorables para la definitiva consolidación del modo de producción capitalista en nuestro país. 
6.1. SISTEMA DE HACIENDA Y RELACIONES DE PRODUCCIÓN EN LA SEGUNDA MITAD DEL SIGLO XIX

Según las consideraciones precedentes, podemos decir que en la primera mitad del siglo XIX las exportaciones presentaron un estancamiento. La inserción de la economía colombiana en el concierto del mercado internacional no fue el más favorable, "las disímiles y cortas empresas que procuraron ingresos externos al país, ya fuera la minería, el algodón, el añil, el palo de Brasil, el caucho, el tabaco, las pieles, y finalmente el café, se llevaron cabo en un marco social precapitalista que se erigió en un importante obstáculo para el éxito de aquellas” (Kalmanovitz, 2003:179). Entendiendo la economía como régimen del discurso, como sistema de correlaciones simbólicas, en el intento de dar cuenta de los intercambios materiales adelantados en el período, es posible, entonces, ir aparejando los comentarios de los historiadores de la economía no con un referente objetivo al que ellos se acercarían con más o menos exactitud, sino al modo como las conclusiones de este tipo de análisis son el resultado de la autocomprobación de sus mismas categorías, la economía funcionando como lente que configura -y no refleja- significativamente los acontecimientos de los que habla, enfrascada toda esta perspectiva en la pregunta acerca del modo como se implementaron las relaciones de producción capitalistas en nuestro medio, el momento en que se abandonaron relaciones de sujeción tradicionales para dar lugar a procesos de producción, circulación y consumo propios de sociedades industrializadas, situadas con claridad en el concierto de la división internacional del trabajo. El cambio en la forma de comprender el análisis económico de la época es sutil, ya que no propone una línea de penetración argumentativa radicalmente nueva, sino que precave sobre el funcionamiento argumentativo de los modelos de representar la realidad, evidenciando su punto ciego, permitiendo exteriorizar y hacer permanentemente visible la naturaleza lingüística y por ende ambigua e incompleta y muy polisémica de las matrices de análisis económico.

Por ello esta descripción está atenta al manejo que el discurso económico, en tanto operador de inteligibilidad, hace de los eventos, produciendo un efecto de realidad enteramente distinto al generado por protocolos de habla como el de la sociología, el Derecho o incluso la novela histórica. De tal suerte se realiza transición paulatina, y en el caso de Caro atravesada de paradojas, a una economía de mercado propia del modelo capitalista industrial. 
Además de la variabilidad de los precios internacionales, se encuentra como obstáculo las relaciones sociales sobre las que se soportaba la producción. En este punto seguimos las tesis de Kalmanovitz. Según este autor, los retrasos en el desarrollo económico se deben más a las represivas y arcaicas relaciones de producción que a la variabilidad de los precios internacionales:

"si bien es cierto que el imperio hispánico extrajo cuantiosos excedentes mineros y comerciales de la actividad productiva de la Nueva Granada, es más cierto aunque los impedimentos a la acumulación del capital se encuentran más del lado de las relaciones sociales imperantes, que frenan la ocupación amplia y democrática de la tierra con miras a extraer del campesinado apenas unas míseras rentas, y no dependen tanto de las restricciones al comercio y la producción impuesta por la administración colonial" (Kalmanovitz, 2003:107).

Estas relaciones, en la Hacienda como unidad de producción, aunque retardatarias, se diferencian a las desarrolladas en el marco de la colonia; sin embargo, es el sometimiento de los mestizos e indígenas el que no permite el avance en el marco de la economía. Diferentes estudios sugieren que no se puede decir que exista una continuidad entre las relaciones de la colonia y las de la República. No "existe una continuidad lineal entre las dos fases históricas: por el contrario, se da un cambio de ritmo, una ruptura del esclavismo, un fortalecimiento de otras formas de producción y circulación" (Kalmanovitz, 2003:103). Pero los mismos apuntan a señalar que los cambios se inscriben en el fortalecimiento del sistema de haciendas, "algunas tendencias visibles desde antes se profundizan, otras se invierten, para consolidar en su conjunto un regresivo sistema de haciendas que logran en gran medida monopolizar la tierra y someter un importante sector de la población" (Kalmanovitz, 2003:103).

La ausencia de libertad, en términos de un mercado de fuerza de trabajo, es el rasgo característico y la herencia del legado español para los mestizos e indígenas. No se daban algunos de los principales rasgos características del mercado: libertad, oferta del recurso y equilibrio del precio (salario) por medio de la oferta y la demanda. Esta es la opinión de Salomón Kalmanovitz.

A mediados del siglo se presentan cambios significativos en la dirección económica del naciente país. El proyecto liberal es el que se instaura y con el aparecen consignas que pretenden impulsar el comercio internacional, 
promover la libre iniciativa económica, con el consecuente debilitamiento del Estado central; situaciones que se conectan con pretensiones de tipo regional.

"las influencias externas y en particular el proyecto agroexportador fuerzan al Estado a alimentar los elementos básicos para acelerar la circulación de mercancías y capitales; de ahí las características "modernas", burguesas, que adquiere el régimen político. Estas se expresan en la eliminación de los monopolios estatales, en el libre comercio, en la separación entre el Estado y ese otro Estado corporativo, la iglesia, que se apropia del décimo de la producción agropecuaria y frena la posibilidad de las tierras y de la población, en la abolición de la esclavitud, y en general, en el impulso de la iniciativa privada en aras de la acumulación de capital" (Kalmanovitz, 2003:226-227).

Pero este "impulso" a medidas económicas "efectivamente" tendientes a la consolidación de un proyecto de capitalismo nacionalista que inyecte energía a las fuerzas sociales productivas se realiza, paradójicamente, en el marco de las relaciones sociales de producción ya descritas.

Esta tesis aquí manejada también acoge la lectura que del proceso histórico de la Regeneración tiene Guillen Martínez. El autor dice que los diferentes cambios en la configuración de las relaciones sociales, a nivel de la hacienda, son leídos como reconfiguraciones de la sujeción y fidelidad social. "El sufragio universal reconocido por los liberales entre 1850-1886, implicó en realidad otra obligación para los arrendatarios, la de votar por sus patronos, y la competencia entre los partidos surgió más que todo para ganarse a los artesanos y a los campesinos libres" (Kalmanovitz, 2003:227). Por tal razón concluye Salomón Kalmanovitz: "tal democracia era tan burguesa como el mismo sistema productivo, y su ausencia puede apreciarse mejor si se considera que en general, los campesinos no tenían igualdad jurídica, ni formal ni real, en su trato con los terratenientes" (Kalmanovitz, 2003:227).

Las reformas liberales en relación con la iglesia, en cuanto a la economía, tienen dos consecuencias importantes: a) una liberalización de tierras que van a un mercado de "poca demanda" y b) reorganización del sistema de créditos.

Frente a la primera consecuencia podemos decir junto a Kalmanovitz: "que el régimen liberal se haya atrevido a combatir el régimen corporativo de la iglesia en la cuestión de las tierras no enajenables o de "manos muertas" que obedecen a un presunto poder extraterritorial, pone de manifiesto que el sistema de propiedad entraña definitivamente cierto grado de movilidad 
mercantil (...)" (Kalmanovitz, 2003:223). Pero esta desamortización de tierras no puede decirse que respondan a una lógica capitalista: "desde este punto de vista, las relaciones de propiedad no son estrictamente modernas, es decir, capitalistas, pues la movilidad de la tierra se restringe a compraventas, remates y herencias dentro de la misma clase terrateniente (...)" (Kalmanovitz, 2003:223).

La reorganización del crédito se desplaza a manos de "inversionistas" privados. Con la expulsión de gran parte de los clérigos del territorio de la entonces Colombia deja "libre" este renglón de la economía. Rápidamente los grandes comerciantes, que son los únicos que pidieron acumular riqueza, como intermediarios entre la producción y el consumo de productos nacionales y de las mercancías del extranjero -que era casi lo único que se importaba-, son los que ponen sus excedentes en el intercambio "al servicio" de los hacendados e "industriales".

\section{7. ¿CUÁL PRINCIPIO DE IDENTIDAD NACIONAL?}

Una lectura económica de los procesos de construcción de la nación en la nueva Granada entre 1810 y 1850.

En La República, Platón soñó un régimen político inconsútil, unitario; de tal manera pensaba que las mujeres y lo hijos deberían ser comunes para posibilitar ésta homogeneidad en la que cualquier persona actuaría como padre o como hijo respecto a los demás. El énfasis de ésta politeía está puesto en la constitución de un sistema de gobierno que fuera como un solo organismo, unilateral y monocromático. Frente a ésta alternativa, Aristóteles (La política, II, 1) planteó la irreductible multiplicidad de la polis, su heterogeneidad consustancial e innegable, de tal manera que para el estagirita es impensable una República unívoca como la anhelaba Platón.

Sobre éste fondo quisiera articular algunas apreciaciones al texto de Maria Teresa Uribe y Jesús María Álvarez (1997), en el sentido de aproximarse a la constitución de nación en Colombia en el período inmediatamente posterior a la independencia. Pareciera que el estudio de los investigadores antioqueños se situara en medio del debate entre Platón y Arstóteles, o incluso enteramente contra ambos. Se pretende desmitificar la lectura que ha hecho del período estudiado (1810-1850) una simple continuación de la administración colonial únicamente quebrada con las reformas liberales de mitad del siglo XIX. Atacando éste sofisma, se muestra que esa serie 
de interpretaciones han pasado por alto el hecho de que, bajo el signo de una heterogeneidad de los procesos productivos en la Nueva Granada, se articularon prácticas sociales que imposibilitaron la emergencia de un sentimiento de identidad nacional en éstos territorios.

La hipótesis es sencilla: las políticas del establecimiento colonial en la Nueva Granada habían gravado inespecíficamente algunos procesos productivos, consolidando una situación de anfractuosidad económica que por una parte dificultó el aparecimiento de un mercado interno centralizado (considerado necesario en los análisis marxistas de consolidación de la nacionalidad) y por otra determinó que se formaran particulares élites regionales.

Según los autores, el mito de una Nueva Granada inserta en el mercado internacional como exportadora de materias primas se cae al constatar que, a la sazón, el capitalismo no estaba en una fase de mundialización sino apenas de cristalización en los territorios nacionales de los países de Europa occidental. De tal suerte que es más bien en el manejo de una acumulación de capital especulativo como se caracterizaron los fragmentarios procesos productivos en la Nueva Granada. Esta interpretación economicista lleva a pensar en una quebradiza situación política, la división en etnias irreconciliablemente dispersas; se hablaría entonces de varios "pueblos históricos" que a pesar de coexistir en un mismo espacio y compartir elementos como la lengua, la religión y la sujeción a la autoridad de la corona mantienen un hábitus divergente, un perímetro de cotidianidad marcado por un horizonte de consenso regional, parcial, destotalizado.

Haciendo un rastreo de éstos regionalismos, Uribe y Álvarez enseñan que, según la manera como se ejerció la dominación acorde al modelo económico implementado en cada espacio local (vertical y pomposo en el Cauca y el altiplano cundiboyacense, integrativo en Antioquia o Santander-por razones diversas-, o aglutinador de etnias y estilos productivos distintos como en la costa caribe), se producen configuraciones políticas y sociales irreductibles entre sí, ajenas a cualquier criterio de unificación nacional, donde solo han existido ciertos intercambios en una geografía caracterizada más por la segmentación que por algún vislumbre de comprensividad entre modos de vida asimétricos y dispares.

Habrían dos vectores copresentes en el momento de la lucha independentista: el llamado gobierno de los cabildos y la estrategia puramente militar. Aunque se distribuyen en el tiempo de forma desigual, éstos dos vectores de desterritorialización (respecto al territorio, al esquema 
de modelización político y económico colonial) evidencian un abordaje disímil en la lucha contra la hegemonía española, lo cual llevará a la constitución de percepciones moleculares y diseminadas sobre la identidad nacional y no al establecimiento de un régimen molar centralizado en la República de la Nueva Granada.

Uribe y Álvarez se ocupan luego de examinar los procesos de ocupación de la tierra y del control de la mano de obra para señalar que una vez hecha realidad la dirección de los procesos económicos por parte de los criollos ricos - esa "identidad de guerra" que solo había sido fantasmalmente lograda batalla tras batalla en la gesta emancipadora- no hubo ningún enfoque común para manejar la economía, lo cual, sumado a la heterogeneidad sociocultural, daría lugar a las reformas liberales materializadas en el federalismo.

La ausencia de referentes amalgamantes en cuanto a la forma de diseñar la política económica se tradujo en una satelización de las regiones que ya venían siendo focos de socialización incompatibles con alguna etiqueta nacional. Ésta falta de integración está crudamente representada en el abismo existente entre los derechos formalmente ganados (libertad, igualdad para todos) y el estado de sumisión y franca explotación (según las particularidades regionales) en que se mantuvieron extensas capas de la población (la misma que había coadyuvado en la supresión del yugo español).

Así las cosas entre Platón y Aristóteles (que parten de la clara delimitación de un horizonte - económico y social- compartido para sus politeías) están el estudio de Uribe y Álvarez como prueba de la radical incompatibilidad de intereses en el territorio de la Nueva Granada durante el periodo subsiguiente a las guerras de independencia.

Pensar la identidad es situar las posibilidades discursivas que estratifican las singularidades regionales en un significante despótico: la nación. Seguir las sinuosidades de ésa experiencia es constatar que el concepto de ciudadano como factor de movilización social contra las estructuras de dominación coloniales resultó siendo una añagaza frente al tipo de sometimiento de las poblaciones así "libertadas". Rebasando las propuestas que desde la tradición occidental (Platón, Aristóteles, Marx) han figurado el proceso de fabricación de la nacionalidad, la Nueva Granada muestra cómo lejos de poder llevar a cabo un proyecto económico necesitado de cohesión social, las élites criollas se enfrentaron con irregularidades culturales y políticas que conducirían al desmigajamiento de esos referentes englobadores. 
Podemos ver ahora cómo el interés homogenizador propio del proceso decimonónico de construcción de la nacionalidad, tropezó permanentemente no solo con una insalvable fragmentación regional, sino con una forma de interpretar el concepto "unidad nacional" disímil a la definición convencional de los tratados de ciencia política. Observamos cómo, desde la apropiación que hizo Germán Colmenares del utillaje metodológico emergente a comienzos de la década de los ochenta del siglo XX (desde la lingüística, pero también desde la tropología, el análisis literario y la socio-semiótica), la trama del relato histórico no se articula en el vacío, o según los documentos "hablen por sí mismos", sino que requiere de unos referentes que son cognitivamente contingentes, unos esquemas lógicos que en tanto artefactos históricos -la noción de Discurso de Miguel Angel Cabrera- hacen inteligibles los eventos del pasado. Solo desde esta óptica podemos imaginar los conatos explicativos que, como en el caso de Guillén Martínez, ubican estructuras sicológicas pre-modernas en la base de los procesos sociales del siglo XIX, asi como el carácter policlasista de los partidos políticos liberal y conservador los convirtió en instrumento de pactos entre las élites dirigentes, imposibilitando las reivindicaciones de los estratos subalternos de la población. Del mismo modo, Frederic Martínez propone la categoría de "nacionalismo cosmopolita" para dar cuenta del carácter paradójico e inacabado de la consolidación nacional en Colombia, derivado de la lectura criolla, en un contexto hermenéutico diferente, del ideario nacional europeo. Salomón Kalmanovitz, por su parte, busca comprender el modo peculiar como nuestra economía acabó por insertarse en el mercado mundial, posponiendo la puesta en marcha de políticas macro-económicas propiamente capitalistas. Los textos de Alfonso Múnera, Maria Teresa Uribe y María Teresa Álvares fueron traídos a colación como rejilla interpretativa en la que la segmentación regional, se erigió en obstáculo insuperable, que al cargar un pesado lastre colonial, no logró integrar los intereses incompatibles que reinaban a nivel local y regional una vez "emancipada" la Patria. Pero sobretodo, terminando la centuria, con el advenimiento del proyecto autoritario centralista del que fue ideólogo Miguel Antionio Caro, la regeneración. 


\section{Capítulo Dos \\ MIGUEL ANTONIO CARO \\ Y LA CONSTRUCCIÓN DEL CONCEPTO DE PERSONA}

1. MIGUEL ANTONIO CARO, SOFISTA

El 17 de noviembre de 1898 Rafael Uribe Uribe publicaba en El autonomista una Acusación Caro-Roldán (1985:261), precedida por una caricatura del ilustre gramático y expresidente de la república vestido como un magnánimo rey recostado plácidamente frente a las atroces imágenes de la guerra civil desplegándose ante sus ojos. Ésta representación de la impavidez de un hombre de Estado ante los atropellos cometidos contra la población civil refleja claramente el tono de la crítica de Uribe Uribe, quien no duda en calificar el gobierno de Caro como una administración sin moralidad, "encarnación del Leviatán de Hobbes" (Uribe, 1985:261).

A partir del anterior comentario se propone investigar el carácter evidentemente ambiguo de la personalidad de Miguel Antonio Caro (18431909), en una serie de textos que abordan la complejidad del pensamiento del estadista bogotano. Si seguimos la línea argumental del general Uribe Uribe es fácil percatarse del cariz de las polémicas desarrolladas entre liberales y conservadores a finales del siglo XIX en Colombia. Provistos ambos bandos de un tono acre y rimbombantemente escarnecedor, se han trabado en un pugilismo verbal apenas a la altura de los sanguinarios combates realizados en el territorio de la República; como prolegómeno de la guerra de los mil días y durante su cruel desarrollo se dio lugar a una no menos oprobiosa pugna retórica entre los bandos en contienda, el ala nacionalista del partido conservador contra la facción histórica, así como contra el partido liberal capitaneado en su vertiente más combativa por el propio Rafael Uribe Uribe. En ese sentido afirmaciones como "el señor Caro fusiló, desterró, encarceló, persiguió y empobreció a sinnumero de colombianos inocentes; y fue, en suma, (...), frío, calculador, astuto, inveraz, implacable, sin corazón y sin consciencia" (Uribe, 1985:261) muestran a las claras el nivel de mordacidad alcanzado en ésta disputa. Igualmente los versos de Rafael Pombo "ventiún guardias del derecho/ iPatria!, te harán más provecho/ que cien mil de mercancía" (Arismendi, 1989:185) refiriéndose al manifiesto que, contra Caro, opusiera el liberalismo a través del "grupo de los 21 ". 
Con lo anterior se ha querido señalar que ya para su época era Caro un personaje polisémico, objeto de las más acerbas críticas en contra de un proceder que otros elogiarán hasta el más melindroso de los encomios, como veremos más adelante.

Elaborada la caricatura de Miguel Antonio Caro como hombre carente de todo principio moral, culpable de la ruina espiritual y económica del país, expresado lo anterior en un tono altisonante y abrasivo, descargado como un golpe ineluctable sobre la imagen de uno de los sujetos más encumbrados por la hagiografía histórica tradicional, es posible iniciar la labor de contraste con un artículo de Enrique Restrepo aparecido el 10 de mayo de 1918 en la revista Voces y titulado El último escolástico, breves apuntes sobre la personalidad de Caro (Restrepo, 1918:93), en el que se indaga sobre aspectos del "[de la patria]más celebrado de sus hombres de letras" (Restrepo, 1918:93), de quien "todos sabemos que fue un hombre de genio, y resuena aun en los ámbitos de su venerado nombre, promulgado orgullosamente por la gloria" (Restrepo, 1918:94). Pero al lado del panegírico encontramos ya la cimiente de la ambigüedad: "Caro no fue un filósofo (...)fue el sectario adicto de las doctrinas que heredó" (Restrepo, 1918: 90), de tal manera que ya a comienzos de siglo se empezaba a escribir una literatura que ennoblecía el nombre del inspirador de la constitución de 1886 entre equívocas alusiones a su recalcitrante militancia: "Aquel antiguo decir de <el que no está conmigo está contra mí> jamás habría hallado mejor empleo que el empleo que Caro hace de él" (Restrepo,1918:96), y poco después se añade "cuando nos parece escuchar al señor Caro, estamos escuchando a Goethe, a Aristóteles, a Shakespeare o a Lamartine..." (Restrepo, 1918:98), parece una paradoja que, después, se concluya "no había en él la fuerza genial que libera al hombre privilegiado de la presión del ambiente (...) pesaba sobre él demasiado la opinión ajena para que la propia pudiera hallar expansión. Fuera de nuestro país la personalidad del señor Caro no hubiese descollado ni tendría su nombre otra resonancia que la de un efimero prestigio entre los de su partido y opiniones" (Restrepo, 191:104), para terminar su texto arguyendo "la gloria que disfruta entre nosotros es una de las más justamente merecidas" (Restrepo, 1918:105).

Se cita con la intención de evidenciar el giro operado entre las diatribas incontrastables de Uribe Uribe y éste tono doble de Enrique Restrepo quien pretendiendo apologizar- descubre en el origen de la personalidad de Caro el germen de una indecisión por la que no sabe si ubicarlo entre los más altos exponentes del intelecto de la humanidad o entenderlo en su estrechez mental y su provincialismo sin esperanza. 
En éste orden de ideas podemos traer a colación el estudio que también sobre la personalidad de Caro y al lado de Rufino José Cuervo adelantara Luis López de Mesa (1994), quien además de resaltar la "chispa" y el humor de Caro como habilidades propias de una inteligencia ágil y bien adiestrada deja en claro con profusión de ejemplos la capacidad de intimidación dimanante de un estilo sentencioso y concluyente, digno apenas de los terrores verbales de sus más encarnizados detractores. Por lo cual afirma López de Mesa que el carácter de Caro le recuerda "el culto intransigente del dogma y la liturgia" (1994) como producto de una matriz ambiental y cultural determinante en el resultado final de la personalidad de los sujetos. Se aprecia aquí una perspectiva que, sin dejar de ser laudatoria, se enrumba difícilmente por el intríngulis de las condiciones históricas que habrían acrisolado las virtudes de éstos dos gigantes filólogos, encontrando en ellas la explicación positiva de un modo de ser enérgico y devoto de las particulares circunstancias en que vivieron Caro y Cuervo, para derivar etiológicamente de ellas el perfil de un pensador que, como Caro, detentaría el poder de constituirse como modelo del buen católico, y por ende, del ciudadano arquetípico y de la "Persona" a imitar.

Sabemos que desde un punto de vista historiográfico hubiéramos podido empezar con los aportes que a comienzos del siglo XX la Academia de Historia realizó en la consideración de los procesos históricos en Colombia. De tal suerte parece pertinente ahora involucrar el libro que en 1948 publicara Manuel Antonio Bonilla como miembro de la citada institución. En Caro y su obra (Bonilla, 1948) puede apreciarse en todo su esplendor la mirada tradicionalista que entiende la historia como recensión de los grandes acontecimientos de los grandes próceres de la patria. Difícilmente podrían alcanzarse cumbres líricas como las evocadas por el señor Bonilla, al tratar de dar cuenta de la inmarcesible genialidad de uno de los más grandes hombres que halla nacido nunca sobre esta tierra. El carácter heroicizante, expuesto con una grandilocuencia rayana en lo almibarado, deja claro que Miguel Antonio Caro es una suerte de elegido por los dioses para comunicar a la miseria de la plebe algo de los áureos resplandores de la visión de lo ultraterreno. El texto aborda la multidimensionalidad de Caro para engrandecer a quien pudo cultivar con igual pericia cualquier campo de conocimiento en el que quiso desenvolverse; de tal suerte desfila el joven prodigio como dechado de obediencia y consagración, el poeta egregio tocado por las más deliciosas y conspicuas de todas las musas, el traductor dotado, el académico íntegro y razonadamente severo, el filólogo cuidadoso 
y el gramático extraordinario, el polemista vivaz e invencible provisto de una agudeza envidiable, el filósofo acucioso, el político legislando con la sabiduría del padre eterno, el orador cuya eufonía hechizaba o cuya determinación tornábase sobrecogedora, el economista, el historiador, el magistrado, una efigie de perfección cuyos aportes a la patria apenas pueden medirse entre la imperfección de las palabras que medianamente lo alaban, tratando de verter al discurso la inefable lucidez de lo impronunciable.

Se entiende que aquí nos hallamos justamente en el otro extremo de los libelos liberales; es precisamente por el carácter apoteósico de ésta biografía que ha podido tomar consistencia el mito de Caro como prócer sempiterno, ataviado exquisitamente con las cualidades de un mártir o de un santo; proceder éste materializado en los textos de enseñanza calcados a partir de la mirada convencional de la Academia de Historia.

Por la misma época se publica Miguel Antonio Caro, humanista, refiriéndolo como "uno de los más eminentes humanistas que la raza española ha producido durante el siglo XIX”; aquí, José Manuel Rivas Sacconi (1947) hace derivar de la exquisitez verbal de Caro una igualmente excelsa condición moral, partiendo de su referencial Gramática de la lengua latina se procede a aupar a sus autores en un altar de incolumidad académica y estilística insuperable: "Numerosa, sonora, libre, gallarda, fácil casi siempre, exquisita en momentos culminantes, la versificación corre con el caudal crecido del idioma castellano en toda su riqueza y vigor" (Rivas, 1947:15), dice con relación a la labor poética de Caro y a sus traducciones de Virgilio. Es necesario aclarar que las referencias biliográficas esgrimidas por don José Manuel Rivas en su papel de director del instituto Caro y Cuervo resultan exhaustivas y meticulosemente intercaladas. Empezando por el Elogio del señor doctor don Miguel Antonio Caro, pronunciado en 1909 en la Academia de historia por Marco Fidel Suarez, se hace un recorrido bibliográfico que prácticamente abarca todo lo escrito sobre Caro hasta 1947. De tal manera que la obsesión por la rigurosidad en el manejo de las fuentes se transmite del propio Caro como manipulador de un lenguaje ampuloso a sus más juiciosos epónimos en el marco del ya consolidado instituto Caro y Cuervo, bastión de la pureza de los estudios idiomáticos en nuestro país.

Vale la pena acotar la obra de Miguel Aguilera Las ideas estéticas de Miguel Antonio Caro (Aguilera, 1950), quien en clara correspondencia con Rivas y Bonilla, se suma al coro de glorificadores del ínclito humanista bogotano; publicada en 1950, Las ideas estéticas discute la situación de los 
escritos de Caro entre las escuelas estéticas y artísticas de la época, no solo para explicitar las posibles influencias sino para demarcar su producción estilística. En esa dirección se dice: "la elegancia de las expresiones, la diafanidad de las frases que llevan sobre sí la carga preciosa de un pensamiento, la tersura de los giros, la sonoridad de los vocablos, (...) son otras tantas combinaciones amparadas por la belleza idiomática (...)" (Aguilera, 1950:11) para concluir terminantemente "El señor Caro no se conforma con emitir su importante opinión sobre las modalidades de construcción que aventajan a las ordinarias o comunes, sino llama en su apoyo, con ejemplos elocuentes, a los grandes veteranos del Lacio: Cicerón, Virgilio, César, Horacio, Catilina, Terencio, Ovidio, Salustio, Tito Livio, y a todos aquellos que alentaron la vigilia del genial bogotano desde el foco radiante de sus libros áureos"(Aguilera, 1950:11). Se ha interpolado la opinión que sobre estética poseía Caro por considerar indisociable ésta dimensión literaria de su devenir político y particularmente de su opinión sobre el régimen de gobierno recomendable para nuestro país. No podría separarse la producción estética de un autor de sus convicciones políticas y argumentativas, de tal manera que el preciosismo expresivo puede leerse de la mano de un conato de acendramiento sobre las prácticas más vulgares y cotidianas de los individuos.

Lo que quiere señalarse es, cómo a partir de un manejo excluyente de las leyes de composición y aderezamiento de los versos "imposible fijar el instante preciso en que la mente de Caro adquirió la plenitud de su principado, porque todas sus producciones gozan de una perfección ideal" (Aguilera, 1950:11), se sigue un manejo excluyente e idealizado del gobierno y control de los individuos.

Se introduce aquí un quiebre en la trama argumentativa de éstos apuntes: se han querido presentar hasta ahora algunos puntos enunciativos que dieran cuenta del carácter polívoco del pensamiento de Miguel Antonio Caro. El hilo un poco desordenado ha querido respetar las intervenciones de quienes desde Uribe y Rafael Pombo han ocupado toda la gama de opiniones sobre el no gratuitamente llamado Polígrafo. Escudriñando por los rasgos personológicos de Caro, nos hemos topado con todo un abanico de posibilidades donde la primera conclusión es la constatación de su temperamento volátil y ambidiestro -captado sutilmente en unos casos y en otros de forma rampante desde las diversas ópticas presentadas-. 
Pero está claro que las indagaciones que quisieran evocar el perfil caracterológico del polígrafo bogotano necesariamente se engarzan en consideraciones que giran de sus preferencias estéticas y poemáticas hacia sus posiciones más claramente políticas. Podría en éste nivel adelantarse una esbozada línea de análisis: aquella interesada en hallar las homologías entre el campo de las reglas gramáticas y el espacio de las reglas sociales. Se sabe que, no abusivamente, puede intentarse una pesquisa de ese talante (Florez, 2001), pero quisieran proponerse algunas directrices en el emparejamiento del buen uso de la lengua tal como celosamente lo dictamina Caro y el buen comportamiento social acorde a leyes y pautas de conducta asumidas como irrebatibles, dimanantes de la incontestable autoridad de Dios y sometidas a su inescrutable e incomprensible benevolencia.

Es en ese sentido que se hacen las siguientes consideraciones. Cuando en 1979, Rafael Torres Quintero publica Caro, defensor de la integridad del idioma, podemos hallar evidencias de la culminación del proceso mitificador iniciado inmediatamente después de su muerte, proseguido proficuamente tanto por la Academia Colombiana de Historia como por la Academia Colombiana de la Lengua (fundada entre otros por el mismo Miguel Antonio Caro en 1881) y consolidado con la labor encomiástica del Instituto Caro y Cuervo (creado mediante la ley $5^{\text {a }}$ de 1942). Ya para ese momento han aparecido tesis de grado como La filosofía política de Miguel Antonio Caro, de Antonio Copello Faccini, que encuentran en la semilla del político y estadista la base no solo de un ensalzamiento sin trascendencia sino que además "el acercamiento a la obra de Caro es utilísimo para encontrar cimientos sólidos de un futuro programa de acción, que está en mora de realizar la generación joven" (Copello, 1959:3).

Así las cosas, encontramos en el pensamiento político y moral de Caro la fuente de un imaginario que pretende restituirle un lugar entre los ideólogos de una nueva concepción del Estado y el Derecho. De la misma manera en 1977 se publicó en la Revista de Policía de Colombia (1977) una edición especial dedicada enteramente a Miguel Antonio Caro; allí se publicaron artículos como el de Fernando Caro Molina Resumen biográfico sobre don Miguel Antonio Caro; Caro, constituyente de Jesús Estrada Monsalve; Caro y la lengua castellana por Luis Flórez; Caro panamericanista de Jaime Ospina Ortiz; así como una revisión del pensamiento crítico literario de Caro compuesta por Francisco Suarez Pineda. En éste conjunto de ensayos se percibe un tratamiento de fuentes tanto primarias como secundarias en el desnudamiento de los diversos aspectos de Caro que intentan explicitarse; 
casi todos ellos se apoyan en las publicaciones y la labor de desvelamiento adelantada por el instituto Caro y Cuervo, que ya para ese momento se erige como un organismo ineludible en la dilucidación de cualquier temática relacionada con el idioma y la lengua en nuestro país.

Seguidamente parece importante destacar la aparición en el boletín cultural y bibliográfico del Banco de la República en 1979 del opúsculo La lengua española y Miguel Antonio Caro, donde no se escatiman frases como "Caro dilató con don Andrés Bello los horizontes del español" (Banco de la República, 1979:171) y que por sí mismos hablan del encarecimiento de los aportes analizados.

Está claro que las citas aquí esgrimidas no tienen la falaz pretensión de ser exhaustivas; se reconoce que la literatura escrita alrededor de la obra y el pensamiento del autor que nos ocupa excede con mucho el carácter de ésta primera aproximación bibliográfica; simplemente se han recogido como indicadores de la clase de elaboraciones que se tejieron sobre la labor desempeñada en diversos campos de conocimiento por parte de Miguel Antonio Caro.

Utilizando como hito la ya mencionada obra Caro, defensor de la integridad del idioma ${ }^{3}$, podemos articular un eje de simetría cuyo propósito es hallar puntos de conexión entre la integridad del castellano y la integridad del proyecto político regenerador, vale decir, ubicar la defensa del idioma correlativamente con una defensa por el sistema de dominación implantado por los regeneradores y que, a través del recurso al catolicismo, a la hispanofilia y a un centralismo político y económico definido, planteó el ejercicio de un disciplinamiento social inexcusable y autoevidente.

A partir de las anteriores disertaciones se dibuja el aglutinante de éstas anotaciones dispersas: precisar la personalidad de Miguel Antonio Caro en un intento por rescatar un cierto nivel de coherencia de entre el enmarañamiento de comentarios sobre su obra, particularmente, generando puntos de tensión entre la aparente rigidez de su aparato conceptual, y los matices introducidos en ciertos escritos (Caro, 1962:277-278) que sugieren -desde el punto de vista de quien hace éste ensayo- que Caro es menos monolítico que sus interpretaciones convencionales, que no puede unidireccionalizarse su pensamiento como retardatario y anquilosado (o no solamente reducirlo a la sencillez de ese enfoque), y que incluso puede adelantarse un estudio sobre

(Torres, 1980). 
los detalles específicamente sofistas de su proceder político, como alguien cuyo rostro no era tan definido como se lo hace aparecer en las reseñas y hagiografías, o que por lo menos vale la pena repensar los juicios que hacen de Caro un ultraconservador completamente cerrado a otra cosa que no fuera la defensa de unos ideales estáticos y paralizantes. Sin sostener que lo anterior sea falso, vamos a ver hasta dónde puede tratarse de una estrategia, una argucia propia del más astuto de los sofistas.

Ya en 1961 el Instituto Caro y Cuervo había publicado El pensamiento filosófico de Miguel Antonio Caro (Valderrama, 1961), tal vez la obra más abarcante respecto de las filiaciones ideológicas y conceptuales de Caro. Sabemos que el señor Valderrama Andrade ha realizado los estudios preliminares para la mayor parte de escritos que han ido apareciendo en un esfuerzo del citado instituto por difundir el conjunto de la obra del polígrafo bogotano. Es por ello que se considera clave partir de las semblanzas conceptuales ofrecidas por Valderrama Andrade, en un intento por establecer el decurso histórico de las interpretaciones realizadas sobre Caro. Para Carlos Valderrama no hay duda sobre la homogeneidad del pensamiento del fundador de la Academia colombiana de la Lengua, ya que "para él no hay en realidad vacilaciones en la vida intelectual; tiene, desde el principio, la seguridad de quien posee la verdad y la defiende a toda costa" (Valderrama, 1962).

Para el autor citado, la obra de Caro presentaría una unidad no fisurada por vacilaciones; en lugar de equívocos proliferan las verdades asumidas y los criterios absolutos. Por lo anterior entra a jugar la posición uniformizante de Gabriel Porras Troconis, según el cual "en Caro nada falta de lo que la lógica más exigente reclama para concederle pleno asentimiento al raciocinio: jamás se le encontrará en la desairada posición del sofista embaucador, Su raciocinio es siempre perfecto" (Porras, 1948:394). Están aquí coligados dos de los exponentes del proceso de mitificación arriba mencionado, según los cuales en Caro hallamos el brillo preternatural de las inconsútiles premisas, incontaminadas de dudas o fraccionamientos, una mente prodigiosamente inmaculada, libre de manchas, de malos olores, totalmente ajena al pecado de la contradicción o la duda. Queda claro que al entender la actividad filosófica de Caro básicamente como una lucha desde el tradicionalismo contra el utilitarismo, queda muy fácil asignarle esa condición científicamente asexuada y subordinada a los designios imperecederos de la Divina Providencia. 
Son de ese talante las afirmaciones que animan los estudios preliminares que ha realizado Valderrama Andrade a las demás obras de Caro, donde desde el estrecho marco de un catolicismo interpretativo pretende leer en la pluralidad únicamente lo que sus monocromáticos ojos pueden mostrarle: "es así como tenemos a Caro, católico por definición, en un plano de lucha, siempre culta pero también vigorosa y sin debilidades, lucha que le deparará grandes sinsabores pero que afirmará día a día su personalidad en esa convicción íntima de que solo los valores ultraterrenos valen la pena ser defendidos" (Valderrama, 1962: XLVII, subraya fuera de texto).

Queda primorosamente configurada la imagen del inmutable rostro de un profeta sin hesitaciones, robustecido en la posesión inequívoca de la verdad, de un sola pieza, sin matiz de sospecha.

Frente a lo anterior vale la pena citar el texto de Rafael Torres Quintero (1980), quien resume la polémica sostenida entre Caro y José Manuel Marroquín en los números 874 y 876 del Comercio en septiembre de 1884, a propósito de una cuestioncilla lógico gramatical referente al neutro y a las palabras que se nombran a sí mismas; conceptúa Rafael Torres que: "Caro(...) en su afán tantas veces exteriorizado de corregir a Bello, nos parece aquí un tanto sofistico y caprichoso" (Torres,1980:L) (subraya fuera de texto). Se trata para este autor de situar a Caro como Humanista integral, con la pretensión de evitar "hablar independientemente del filósofo, del jurista, del poeta, del crítico, el historiador y el filólogo como si en él hubieran convivido muchas personalidades notables(...) so pretexto de juzgarlo como hombre de genio polifacético, se corre el peligro con éste fácil procedimiento de que su imagen aparezca como si se mirara a través de un prisma(...)" (Torres, 1980: XXVII) (subrayado fuera de texto) para concluir categóricamente "en el caso de Caro más que en ningún otro, hay en él un único personaje" (Torres, 1950: XXVII). Pero ya vimos cómo al sostener éstas afirmaciones en el caso de su altercado con Marroquín se cambia de tamiz y ya es asumido Caro con un perfil un tanto sofista y enredador.

Algo similar es apreciable en Miguel Antonio Caro, vida y obra, donde Isabel Hernández (1968), al tratar de establecer el ideario estético y filosófico de Caro, hace hincapié en que "la fe sencilla del creyente católico es su norte y a ella se dedica con ahínco, primero estudiándola y luego defendiéndola en el campo de la teología y en el de la polémica religiosa" (Hernández, 1968:93). Pero si "[respecto a Caro] su poesía es síntesis de su yo. En ella se encuentran las ideas estéticas junto a la intimidad del sentimiento" (Hernández, 1968:94) y la”sinceridad, espontaneidad y naturalidad son 
sus recomendaciones" (Hernández, 1968:97), esto no parece coincidir con la falta de espontaneidad necesaria para cumplir los designios de Dios como buen cristiano cuyo norte exclusivo es la fe; es decir, si se sostiene la sujeción a la autoridad de Dios Padre por temor a que las pasiones libres del individuo puedan obrar el mal y solazarse febriles en el pecado, no puede después reivindicarse la espontaneidad y la iniciativa personal; ya aquí es visible un rasgo de la ambigüedad de Caro que sus apologetas insisten en no ver; trazos de una dualidad convenientemente maquillada por aquellos que quieren presentarlo como un personaje sin contradicciones.

Podemos interpolar ahora los comentarios que hiciera Jaime Jaramillo Uribe (2001) acerca de Caro en los capítulos XIX: El pensamiento político de Miguel Antonio Caro y XXIII: La obra y la formación filosófica de Miguel Antonio Caro, en su libro El pensamiento colombiano en el siglo $X I X$; en los que se plantean las ideas de Caro sobre un Estado paternalista $y$ asistencial, encargado de educar moralmente a sus ciudadanos.

De lo anterior se deriva la imagen de Caro como el adalid de una concepción puramente espiritualista de la personalidad, indesligable de la axiomática cristiana que la ilumina: es por ello que puede afirmar Jaramillo Uribe, refiriéndose al Estudio sobre el utilitarismo (1868) y al Informe sobre la adopción del texto "Ideología" de Tracy por la Universidad Nacional (1870). "En esos dos ensayos se encuentra ya definida la orientación filosófica de Caro, la misma que conservará sin variaciones de significación a través de toda su vida" (Jaramillo, 2001:323), interpretación ésta posibilitada al rastrear en la orientación filosófica de Caro la influencia de tres elementos: el racionalismo cartesiano, el tomismo y la filosofía escocesa, lo que permite articular una visión de Caro como autor ortodoxo que difícilmente logró separarse de las tesis cartesianas profundamente arraigadas en él desde la juventud.

En 1984, el acucioso Instituto Caro y Cuervo publicaría La vida de Don Miguel Antonio Caro, donde Marco Díaz Guevara en su capítulo Gobernar es vigilar sitúa el marco convulso en el que Caro desarrolló su actividad como estadista: "bajo las responsabilidades echadas sobre sus hombros, conservaba el equilibrio psicológico, que suelen los hombres perder en estos casos" (Díaz, 1948:21), pero reconociendo sin embargo que "el ejercicio del poder no fue sino un continuo cáliz de amargura” (Díaz, 1948:226); como podría preverse, el tono vuelve a ser el de un martirologio político en el que el presidente Caro se ve involuntaria y sañudamente envuelto, de tal 
manera que las polémicas determinaciones del gobernante son excusadas con el argumento de que "el poder aletarga y enerva, tanto como la política apasiona y enceguece" (Díaz, 1948:233), manteniendo el ícono de un Caro unificador cuyos caprichos se justificaban como los de un padre que por el bien de sus criaturas se puede permitir algunos desafueros correctivos, para bien de los gobernados.

Cronológicamente, es conveniente traer a colación un pequeño escrito que tal vez contenga en síntesis los elementos que se han querido reseñar en este capítulo. Se trata de Miguel Antonio Caro en ediciones y estudios (Schütz, 1987), donde Günther Schütz - de la Universidad de Erlangen en Alemania- plantea, desde la óptica de un extranjero, una elogiosa revisión de los aportes lingüísticos de Miguel Antonio Caro. Proponiendo una fusión entre identidad cultural y unidad religiosa, se hace un balance bibliográfico de la producción del Instituto Caro y Cuervo frente a las obras más relevantes que se han escrito sobre Miguel Antonio Caro.

Contrastando con el recorrido del lingüista Alemán, encontramos una crítica que servirá de punto de encaje para la tesis central de estos apuntes historiográficos; se trata del libro de Malcom Deas cuya primera edición es de 1993 y que definitivamente constituye un cambio de orientación en la manera de asumir la obra del tenaz tribuno bogotano (Deas, 1993). Para Deas lo interesante del análisis está en la correlación existente entre un uso correcto del lenguaje y las relaciones de poder mantenidas mediante este ejercicio. Sabemos que Miguel Antonio Caro dominaba el latín a la perfección y lo consideraba como modelo morfosintáctico de la lengua castellana, pero ya ante la pregunta por las razones para escribir y hablar en un idioma prácticamente extinto respondía "quizás para que no me entiendan" (Caro, 1980: XXIX). Queda suficientemente expuesto el ardid retórico del ilustre señor Caro; al practicar un idioma exclusivo, así como al establecer unas normas de compostura gramatical que solo dominaban unos pocos dispone una tramoya como rejilla de diferenciación frente a los no iniciados en el esoterismo de esas artes gramáticas.

El estudio de Deas apunta precisamente en esa dirección, muestra cómo, la práctica del latín otorgaba un criterio de distinción que no se agotaba en el prestigio social de hablarlo y escribirlo con fluidez (al punto de poder realizar traducciones de Virgilio internacionalmente catalogadas como excelentes); sino que se constituía en medio de coerción sobre la masa de los legos, la turbamulta ignara que debía someterse al mando de los especialistas. Precisamente de eso se trata Del uso en sus relaciones con el lenguaje; en 
este discurso leído en la sesión inaugural de la Academia Colombiana de la lengua, a lo que apunta Miguel Antonio Caro es al establecimiento de un patrón de uso del idioma que no es otro que lo que digan los notables, los hombres ilustres, los sabios iluminados, los depositarios de la moral y las buenas costumbres, en últimas él mismo -en su disfraz de filantropía-.

Podemos decir entonces, que la perspectiva de Malcom Deas nos abre el espacio analítico necesario para sostener la hipótesis central de esta tesis: Caro, visto a lo largo de la historia tanto en el papel de ángel como en el de demonio, preservándose así una anfibología que no vemos superada en los textos que desde el Instituto que lleva su nombre, pretenden purificar la imagen de un Caro engañoso en un hombre público de reputada probidad y comportamiento ético intachable.

Las ponencias presentadas a la Cátedra de pensamiento colombiano involucran en cierta medida ésta dimensión de análisis (publicadas en Sierra, 2002). El trabajo de Lisímaco Parra Miguel Antonio Caro y la moral utilitarista señala las falencias de un catolicismo pre-moderno como motor pedagógico para una población claramente sumida en el analfabetismo resultante del abandono estatal. Rodolfo Arango en La construcción de la Nacionalidad en Miguel Antonio Caro profundiza en el aspecto religioso del proyecto regenerador como ingrediente cardinal en la nacionalización de la identidad en Colombia.

Por otra parte, en la misma compilación, David Jiménez en Miguel Antonio Caro: Bellas letras y literatura moderna discute las relaciones entre las ideas estéticas de Andrés Bello y Miguel Antonio Caro, subordinando éste último, el problema de la estética a los férreos comandos de la religión. En Miguel Antonio Caro, el banco Nacional y el Estado, Salomón Kalmanovitz pondera los factores económicos intervinientes en la formulación de una política económica que durante el período de la regeneración habría determinado la instauración de una banca central y el monopolio en la emisión del papel moneda. Especialmente relevante resulta la ponencia de Adolfo León Gómez, quien partiendo del tipo de polémica adelantada por Caro en algunos debates de corte teológico, se propone entender El estilo argumentativo de Miguel Antonio Caro.

Se han mencionado solo algunos de los aportes para una historización de las interpretaciones del pensamiento de Miguel Antonio Caro. La perspectiva historiográfica se alcanza toda vez que reconocemos en los textos sumariados un paradigma histórico que como modelo cognoscitivo, 
diseña las posibilidades hermenéuticas del discurso. La posición asumida en éstas líneas se sabe también tributaria de un paradigma desde el cual se trama la hipótesis que sugiere comprender a Caro como sofista, articulando los diversos aportes que desde el texto de Uribe Uribe hasta la Cátedra de pensamiento colombiano efectuada en el año 2001, se han aproximado a la obra compleja de este pensador polisémico.

2.

\section{LA CONSTRUCCIÓN HISTÓRICA DE LA PERSONALIDAD}

Esta parte del trabajo busca, en el discurso de Miguel Antonio Caro, escudriñar los procesos de construcción de la personalidad colombiana. Queremos encontrar cómo se construye el sujeto, individual y colectivo; verificar a través de cuáles mecanismos se pretende construir gramaticalmente "la fronda retórica que unánimemente atribuye a la regeneración el carácter infraestructural de una revolución esencialmente filosófica" (Guillén, 1986) y sus implicaciones sociales.

Ya hemos dicho que la con-centración es el elemento esencial de la persona, en la definición que maneja Caro; pero, ¿esto qué implica?, " $L a$ consigna de la Regeneración exige la entrada de dos empresas prioritarias: la instauración del centralismo político y la rehabilitación de la iglesia como principal actor social" (Martínez, 2001:432). Empecemos entonces con el contexto político.

\subsection{SOBERANÍA Y CENTRALISMO}

A nivel de la persona jurídica "Colombia", la centralización política tiene relación, en principio, con LA CONCENTRACIÓN de la soberanía: "la proclamación de la soberanía nacional es la primera muestra de la resurrección de este cuerpo político que llama la patria. Ya no hay república diseminada; ya no hay soberanos coexistentes; la nación es una, y una es la autoridad" (Caro, 1986a:91). Ya no más patrias bobas o brutas. Para el regenerador bogotano las constituciones que imperaban en Colombia, anteriores a 1886, padecen de un error flagrante, "la contradicción que resulta de tres soberanías -individual, provincial y nacional-" (Caro, 1990b:34).

La disgregación de la soberanía por parte de los regímenes federalistas condujo al país a un movimiento constante entre anarquía y dictadura. La 
multiplicidad de soberanos acarrea una lucha por el poder, generando una soberanía nacional desprotegida y sin elementos que puedan resolver la situación; solamente el más fuerte, con los ropajes del tirano, era capaz de aplacar, de orquestar, eufonizando, la multitud de voces dispersas, ruidosas: "la Constitución de Rionegro, reconociendo la soberanía regional e individual, como coexistentes con las soberanias nacionales, prohibiendo la penalidad y despojando así de sanción a la autoridad, admitía implícitamente el paradójico "derecho de insurrección", y fue, en suma, una ley fundamentalmente revolucionaria" (Caro, 1990b:292), añadiendo luego, "del desorden, cuando llega a los extremos, nunca han salido los pueblos sino por medio de una dictadura única, que sobreponiéndose a los dictadores de provincia y aldea, que enseña a obedecer a todos los que quieran mandar; o bien, por medio de movimientos colectivos y patrióticos" (Caro, 1990b:292). En este punto se aprecia con claridad la idea centralista como motor del discurso político (desde el adecuado manejo de la lengua) de nuestro autor, quien se expresaba así acerca del estado de cosas que originó el federalismo en Colombia:

"la revolución de 1860, consecuencia del desorden de consumo por todos los partidos en la ley, engendró, a nombre de la libertad, como era natural, la dictadura militar del General Mosquera; tras la dictadura debió venir, como de ordinario sucede, el orden legal; pero los legisladores de Rionegro, sordos y ciegos, llenos de soberbia y faltos de caridad, negando a Dios voz y voto en las deliberaciones sobre la suerte de los pueblos, continuaron la obra jurídicorevolucionaria, como si aquella obra, apenas iniciada, no nos costara torrentes de sangre inocente" (Caro, 1990b:293).

La soberanía individual, desde esta perspectiva, está representada por una figura de doble hélice: el utilitarista y el gamonal ${ }^{4}$. Según Miguel Antonio Caro, el gamonalismo hizo "tradición" con la idea federal; este personaje envidioso es el constructor de las ideas del utilitarismo en algunos liberales (los radicales). "el origen del gamonalismo, como forma de existencia social, se halla en el estado más o menos bárbaro de las razas indígenas más atrasadas antes de la conquista” (Caro, 1990b:356). El gamonal puede verse, desde la perspectiva de Guillén Martínez como el pináculo de una estructura de sujeción sicológica, que asegura el orden mediante la adscripción inconsciente al sistema de jerarquías propio de la hacienda, en su doble papel de lugar físico de explotación y modelo económico abstracto.

$4 \quad$ La relación utilitarismo y personalidad se tratará con especificidad más adelante. 
Hipótesis ésta en total consonancia con las intuiciones planteadas en el primer capítulo de este trabajo, consistentes en asumir el pasado y por ende la realidad que maneja la persona como un efecto del funcionamiento de las mencionadas "estructuras sicológicas", marcos categoriales o Discursos (Cabrera, 2001) que organizan la experiencia de lo real, otorgándole algún sentido.

En éste orden de ideas, el gamonal, guiado por sus intereses personales, por la búsqueda su felicidad, mantenía el Estado en constante pugna, sin importar el sentimiento nacional ni permitir el progreso de la patria:

"Mientras la ignorancia o la mala fe reclama contra el exceso de centralización, los departamentos ven aumentar considerablemente sus rentas y las administran libremente por medio de corporaciones populares; en todos ellos libres de la zozobras de los abolidos cacicazgos, se palpa el adelantamiento material, y algunos han iniciado obras de gran entidad" (Caro, 1991:356).

Se trata de una posición moral egoísta, derivada del federalismo, que será el blanco de las críticas de Caro, en un intento por configurar una Identidad nacional lingüística y políticamente estable, una vez se ha logrado diferenciar con claridad teológica de un Otro descentrado, malvado, intrínseca e indiscutiblemente nocivo: las ideas liberales.

\subsection{CONFIGURACIÓN DEL ESPACIO-POLÍTICO}

La labor unificadora que venimos mencionando también encuentra su referente en la denominación territorial: "Un solo territorio, un solo pueblo, una sola lengua era la tríada sobre la que, como sabemos, se habian constituido los principales Estados Europeos" (Cubides, 2002:322). Tal como lo vimos en el balance historiográfico sobre el siglo XIX, el territorio con sus consecuentes representaciones, constituyen uno de los elementos más importantes en la construcción de la Nación. Sobre la construcción y el imaginario que se tracen sobre el mismo se representan, modelándose, las formas e intenciones del poder. Por ello, la inclinación que durante el siglo XIX tiene las élites no es una pretensión desinteresada; SOBRE ELLA SE CONSTRUYEN IMÁGENES DISCURSIVAS QUE TIENEN EFECTOS DE REALIDAD, TANTO EN LA TOMA DE DECISIONES COMO EN LAS PROYECCIONES POLÍTICAS: "la división, lo más racional posible, del territorio no busca principalmente resolver necesidades administrativas, sino que es una realidad para la representación política" (Cubides, 2002:323). Caro, adalid del proyecto regenerador, eligió una fórmula que 
proviene de Francia, para resolver la necesidad de unificar entorno a un centro: “ (...) y, consiguientemente, a medida que los proyectos geométricos suscitaron reacciones y reformulaciones hasta llegar al proyecto de creación del departamento que finalmente se adoptó, siguiendo el caso de Francia, la representación del territorio, según un patrón racional, hace evidentes la homogeneidad y a la vez la complementariedad de las regiones" (Cubides, 2002:323). Esta denominación que asumieron los Estados en 1886 racionaliza una pretensión de los sectores dominantes: conjuga su idea de unidad (homogénea en torno a un pueblo inspirado en la civilización cristiana) y la complementariedad (a través de la cual se ocultan las profundas brechas regionales trazadas por el devenir histórico).

El desconocimiento de la diversidad y los procesos regionales que no pueden ser tratados desde Bogotá, se sintetiza en la actitud de M. A. Caro frente a la geografía: "Uno se sus biógrafos y varios de sus contemporáneos narra cómo Caro se preciaba de no necesitar un conocimiento directo del territorio para poder gobernarlo; en su vida, prácticamente no salió de la sabana de Bogotá, y lo más lejos que pudo haber llegado fue San Gil, en el actual departamento de Santander" (Cubides, 2002:335). Recordamos aquí lo mencionado por Alfonso Múnera, abordado en el capítulo tercero, quien fortaleciendo la tesis de Uribe y Álvarez, reconoce la imposibilitad tanto geográfica como política y económica, de superar la fragmentación regional heredada de tres siglos de dominación colonial.

Por otro lado, en las discusiones de la asamblea constituyente de 1885, ardua fue la confrontación respecto a si las divisiones territoriales debían llamarse departamentos o Estados. El miedo a la anarquía fue tan grande que por ello no se sigue la regla general respecto de la división territorial civil (ésta le compete a la representación nacional civil por medio de una ley ordinaria), precisamente

"porque así como el trastorno del juicio, el error de entendimiento tuerce la voluntad, y ocasiona conducta viciosa y funesta, la contradicción en las leyes fundamentales de la nación, se traduce luego en hechos y la propia discordia sembrada en las leyes no tarda en germinar, y aparece al fin en forma de discordia civil efectiva (...) tal sería el caso si tratamos de dar a las asambleas departamentales el carácter de legislativas, renovando asi la dualidad de soberanías, o si, en el caso como el presente, dejar a esas corporaciones la iniciativa para variar la división territorial" (Caro, 1986a:92).

El señor Caro optaba por dar el nombre de "departamentos" a las nuevas unidades administrativas bajo dos argumentos: el primero, sería el renacer de 
la antigua denominación que refuerza los nombres, hombres y glorias de los padres fundadores, como veremos en el apartado referente a la concepción de Historia de Caro, y en segundo lugar, el Estado es una denominación que refiere a la idea de Nación.

\subsection{El pensamiento económico de Miguel Antonio Caro}

Miguel Antonio Caro, como mandatario e ideólogo de la regeneración, tuvo un papel destacado en la consolidación del Banco Central, eje del modelo económico que rigió el país durante este período:

"Caro recoge la tendencia continental europea de instaurar bancos centrales de carácter público que tiene a su cargo el monopolio de la emisión y la adapta a Colombia, aunque el Banco Nacional no será un banco central en su sentido de regulador del sistema financiero y prestamista de última instancia. Por el contrario, el banco colombiano será planteado básicamente como financista del gobierno, eventualmente como competidor de la banca privada y no como su complemento, y estabilizador" (Sierra, 2002:189).

En la práctica el Banco Nacional sirvió de financiador de la guerra, especialmente la de los mil días, en la que la "emisión libre de moneda" produjo serios problemas en la economía nacional de la época, sobre todo en lo que tiene que ver con el fenómeno denominado inflación ${ }^{5}$.

Este uso del papel moneda lo podemos sintetizar en esta frase de Caro, frente a la derrota de sus enemigos políticos de 1885: "la revolución hizo nacer el papel moneda, y el papel monda mató la revolución” (Sierra, 2002:197).

Caro, desde este punto de vista, considera que la moneda barata es un aliciente para el desarrollo, sobretodo en países que por su condición

5 "Mientras los bancos europeos y la tesorería norteamericana mantenían una credibilidad sobre una emisión limitada por medio de respaldo de oro que tenían sus billetes, Colombia introdujo en 1886 el curso forzoso del papel dinero, que no tenía otra garantía que la voluntad superior del Estado. La emisión monetaria fue objeto de abuso como cualquier otra área de actividad estatal durante los últimos seis años de vida del Banco Nacional, cuyo rol fue asumido después por la Tesorería, con lo cual la inflación aumentó progresivamente entre 1880 y 1898 (estamos dentro de los periodos en que Caro se despeñó como primer mandatario y Vice-presidente). Los abusos para financiar la Guerra de los Mil Días condujeron a la sociedad al terreno de la hiperinflación” (SIERRA, 2002:191). 
económica necesitan en abundancia de este recurso para sopesar su carencia en la producción:

"La moneda cara es un lujo de pueblos ricos, y el pueblo atrasado que, preocupado por ser rico, se empeñe en competir en fondos pecuniarios con aquellas naciones a las cuales no puede emular en población, organización y en industria, presenta claramente signos que su debilidad fisica se agrava con su debilidad mental" (Sierra, 2002:196).

Esta práctica frente al papel moneda es paralela a lo expresado por Rafael Núñez en 1884, el cual, frente a una crisis en la cuenta corriente del país, dispuso la salida económica más inmediatista ${ }^{6}$.

En conclusión, la afirmación hecha por Caro sobre el rol de la "moneda barata" en el desarrollo tuvo tales efectos mientras no se emitió papel moneda excesivamente, manteniéndose la credibilidad en el mismo. Pero tal situación duró poco y condujo a las "rachas inflacionarias de 1885-1893, y especialmente la de 1899-1902, destruyendo buena parte del capital líquido y de los negocios de la época”. (Sierra, 2002:200). Esta carencia de credibilidad podría decirse que inició en 1886, cuando se dijo, por decreto, que por el valor de los billetes no se respondería con oro y plata.

Debido a los desastres que produjo esta política económica Caro cambia su perspectiva sobre la moneda. Hacia 1894 se reconoce que el monopolio en la emisión de moneda por parte del Estado es peligroso. Dice nuestro autor que al Banco Nacional le faltó "el interes privado que por inspiración propia corrige la tentación de la prodigalidad y el favoritismo (...) un banco netamente oficial ofrece inconvenientes palpables" (Sierra, 2002:203). Junto con sus críticas hacia el banco central, arremete contra la Tesorería de la Nación, causante según él, en 1902, del mal hiperinflacionario.

Caro es uno de los expositores de la teoría del banco central ingerido por el gobierno (teoría que, como ya vimos, dejaría de sostener). Esta opinión es conocida por sus debates con Miguel Samper. Este autor pensaba "que era mejor que el gobierno impusiera tributos a la fuerza y no controlara el

\footnotetext{
6 "El régimen de la moneda de papel es, como todo el mundo lo sabe, la oscilación permanente en los precios, la cual hace posible todo cálculo preciso en las operaciones industriales, y es un peligro continuo para toda propiedad circulante. Si el oro y la plata han sido escogidos para la fabricación de moneda, ha sido precisamente a causa de la estabilidad relativa de su valor intrínseco. La moneda de papel es el reverso de esta estabilidad y, solo puede recurrirse a ellas en horas de desesperación para dar aumento a las transacciones" (SIERRA, 2002:198).
} 
poder de emitir dinero falseado" (Sierra, 2002:205). "El empréstito forzoso tiene la ventaja de que en él se aprecia la cantidad que se exige; en raros casos se pide al prestador todo lo que tiene, de modo que puede contar con lo que le queda; se guardan consideraciones a la viuda, al huérfano, al enfermo; y al pobre solo se le manda tomar el fusil, ;más que no reciba, en cambio de su jornal, moneda falsa!" (Samper, 1967:204). Frente a estas afirmaciones Caro responde que el papel moneda "representa un interés solidario, nacional y social, por encima de los intereses de los que están sufriendo la pérdida de su poder de compra" (Sierra, 2002:205).

Por último, señalaremos la opinión y la actitud de Caro frente a los aranceles. La regeneración, al fortalecer el Estado, impuso medidas arancelarias contrarias a las estrategias antes dictadas por los liberales:

"La filosofía fiscal que expresa Caro es la de un Estado central que se apoya precisamente en un arancel a las importaciones, incluso en impuestos a las exportaciones, que son la única avenida de expansión de la economía nacional, en el impuesto inflacionario; no quiere oír hablar, en todo caso, de otros impuestos más progresivos y sustanciales. El arancel y el impuesto inflacionario (aquí lo denominamos inflación) aparecen como gratuitos pues no recaen sobre los productores locales, pero ambos son indudablemente costosos en cuanto a los precios de las mercancías importadas y en todos los precios en el caso de la inflación que arrebata, caóticamente a veces, una parte de las rentas y los ingresos fijos de la población" (Sierra, 2002:217)7.

2.4. LA HISTORIA, LA LINGÜÍSTICA Y LA NACIÓN PARA MigUELANTONIO CARO

"Siempre repetiré que la historia de nuestros Estados soberanos ha sido bien triste, y que la división territorial de la república en departamentos es una restauración enlazada con honrosos recuerdos y con gratas esperanzas" (Caro, 1986a:84).

Para Caro la labor de los Libertadores fue la emancipación, y su inconclusa tarea fue la instauración del orden, esto manifestado en las constituciones de principios del siglo XIX. "La comisión adoptó para la división territorial la

Esta fue la estrategia que utilizó Caro para aliviar la crisis inflacionaria de 1895. "En 1895 Caro enfrenta la crisis fiscal imponiendo un tributo a las exportaciones de Café y aumentando los precios del monopolio de la sal y del tabaco" (Sierra, 2002:217). 
denominación de las constituciones de 1824 y 1830. La antigua república de Colombia se divide en ocho departamentos. ¡Ojalá que en la nueva Colombia renazcan nombres, hombres y glorias de la antigua!". (Caro, 1986a:83). Aquí puede apreciarse con nitidez lo que Nietzsche en su segunda intempestiva "Sobre el utiidad y perjuicio de la historia para la vida", llama historia monumental ${ }^{8}$, denunciando como la esterilización de la vida operaba al erigir al pasado grandes monumentos que lo reifica, impidiendo vitalizar esas perspectivas anquilosadas. En el caso de Caro encontramos constantemente este recurso a moldes de legibilidad que fijan el pasado en un recuento de grandes acontecimientos, siempre a la sombra de personajes moralmente ejemplarizantes

En este orden de ideas recurre de nuevo nuestro autor a la historia para señalar como la tradición y la tarea libertadora fueron traicionados por las formas de organización territorial propias de los regímenes federales. "Los Españoles que conquistaron y colonizaron la América, trajeron aqui los sanos elementos de su civilización, pero no importaron, ni estaba en su mano hacerlo, la aristocrática y feudal geografía del antiguo continente a las virgenes selvas y dilatadas llanuras del Nuevo Mundo" (Caro, 1990b:355). Además resalta como hombres como Camilo Torres y Bolívar soñaban por la unidad Andina y latinoamericana. Incluso señala el anhelo de unidad en la separación con Venezuela; explica que los libertadores no sabían cómo había de quedar la nación hispanoamericana. A partir de 1830, se divide la Gran Colombia y se fija definitivamente. Incluso rescata el pensamiento de Santander, porque según Caro, aquel "volvió a sostener el sistema unitario, que los liberales sancionaron al expedir la primera constitución de la Nueva Granada (1832)" (Caro, 1990b:358).

Por eso al saludar, en una alocución presidencial, a los hombres que continúan la tarea del ejército libertador, la guarda de la soberanía y el mantenimiento, les recuerda:

";Conciudadanos del ejército! Grato me es sobremanera poder corresponder a las reiteradas muestras de aprecio con que me habéis favorecido, saludándoos en esta gloriosa fech a como a dignos sucesores de los libertadores de Colombia. Ellos fundaron la independencia; a vosotros debemos la existencia de la nacionalidad, amenazada antes de ahora, de inminente disolución; vosotros

8 Las consideraciones que al respecto hace Michel Foucault en "Nietzsche, la Genealogía, la Historia", resultan fundamentales, a la vez que enlazan con la pretensión historiográfica esbozada en la primera parte de este trabajo. 
nos aseguráis el goce del gran legado, como celosos guardianes de la paz” (Caro, 1991:25).

Dentro de esta contienda también se inscribe la discusión entre Centralismo y Federalismo. Los conservadores, "siguiendo" el legado histórico del Libertador, pugnaban por el centralismo; por otra parte, los liberales, "identificados" con las ideas de Santander, levantan las banderas a favor del federalismo. Sin embargo, estos derroteros fueron cediendo terreno con forme transcurría el siglo XIX. Aunque la constitución de Rionegro, vigente aun en 1880, se sentó sobre las bases federalistas que Mosquera y el grupo de seguidores liberales radicales levantaron, "hacia final de 1879, los liberales radicales habían perdido casi todo el espacio político en la mayoría de los estados que antes habían sido suyos" (Laguado, 2004:57). Además, "la constante agitación, las insurrecciones locales, el poder casi inexistente del presidente para coordinar grandes proyectos y conservar el orden, habían generado un ambiente hostil a la Constitución de 1863 y se había generado un consenso que se resume en la frase de Núnez: "regeneración administrativa fundamental o catástrofe" (Laguado, 2004:58).

Así, los sectores moderados de ambos partidos se unificaron entorno a este consenso. Al ala radical, un sector moderado, llamado independiente, pertenecía Rafael Núñez; quien llegó a la presidencia apoyado por los conservadores.

De la mano de Núñez se instaura un modelo de Estado centralista contrario al que instauraron los liberales radicales. Este modelo de Estado fue del que participó Caro y se vertió en la Constitución de 1886; buscaba ésta "el establecimiento de un sistema político que pudiera garantizar la paz y el orden, acabando con la fragmentación liberal y el perenne conflicto entre Estado e Iglesia" (Laguado, 2004:61). El orden del discurso de Caro se encuentra anclado en este contexto; sus apreciaciones históricas son una construcción retórica que pretende dar sentido a la tradición, el orden natural de las fronteras y de los significados.

Pasemos ahora a examinar esa tradición a la que se suscribe. Dice Caro que el centralismo es una forma de gobierno que se instauró con el gobierno español y que trasciende en la mirada de hombres como Bolívar y Camilo Torres; en otras palabras, que esta forma de gobierno es natural para el pueblo colombiano. Sin embargo, hay otras miradas historiográficas que señalan lo contrario 9 .

9 "El complejo régimen colonial y el aparato administrativo virreinal generaron en la Nueva Granada una heterogeneidad productiva y una fragmentación política (...que produjeron...) una pluralidad de centros mercantiles de diverso carácter, en donde 
Este heterogéneo espacio económico generó una amalgama de círculos en los que se movía la economía y alrededor de ellos se configuró, más que un poder central, una amalgama de regiones. "Así, la heterogeneidad económica y la fragmentación política que de alli resulta definen regiones económicas que acentúan la particularidad regional y coadyuvan a la formación de pueblos históricos distintos, que si bien tienen en común la lengua, la religión y la dominación de la raza blanca, asumen particularidades culturales tan dispares que a la postre constituyen un obstáculo a la formación de la nación moderna" (Uribe, 1987:101).

De otro lado, la unión que generó el proceso de liberación del dominio español, no logró cohesionar al conjunto de la población; las diferentes formas de culturales o pueblos históricos ${ }^{10}$.

Regresando al argumento con el que Caro defiende la denominación de departamento para las divisiones territoriales del nuevo Estado, podemos decir que este es una combinación de constitucionalismo y lingüística. Recordemos que para Caro el lenguaje y las palabras son un elemento de sujeción del orden social; estos dos elementos no son hijos de la arbitrariedad; están atados al orden natural de las cosas que designan. "La noción de Don Miguel Antonio Caro sobre la relación entre los usos adecuados de las palabras y la vida social es sorprendente. Quienes desde la etimología definan adecuadamente los términos, definen los sentidos, y al hacerlos, establecen las reglas de la vida social y política" (Florez, 2001:155). El orden así establecido es irrefutable; la vinculación del significado con la naturaleza y el ser de las cosas es incontrovertible; ir en contra de ellos es ir contra el orden natural. Así, a propósito de un texto sobre la libertad de cultos, dice Caro: "estando en la naturaleza de las cosas la imposibilidad

ninguno de ellos es lo suficientemente importante para absorber y subsumir a los demás, contribuyendo de esta situación a fraccionar y diferenciar el espacio interno" (Uribe, 1987:100).

10 "Pese a que la dominación colonial española enfatizó en la formación de un pueblo que compartiera con la metrópoli los rasgos generales de la cultura castellana, de la administración política y de las prácticas sociales, la heterogeneidad de los procesos de trabajo, unidad a la desigual distribución de etnias dominadas y a sus aportes diferenciales de complementación y/o antagonismo en los diferentes campos de la vida social, dieron como resultado la formación de varios pueblos históricos $-\mathrm{y}$ no de uno solo como se lo propuso la dominación española- que vivieron la relación con los otros hombres y con la naturaleza de una manera distinta". Uribe, M. T. \& Álvarez, J. M. Ibídem, p. 45. 
de libertad de cultos, la ley no puede consagrar tal libertad, porque sería ir contra la naturaleza de las cosas" (Florez, 2001:155).

Desde su posición de legislador de y con la palabra (nadie puede negar su posición de estadista de la lengua), cree en el orden natural de las cosas, orden que se sujeta a un mundo de significados dados de una vez y para siempre, anclados en las raíces de la lengua en la cual se inscriben. "Este retórico guerrero tiene en las palabras su instrumento para, ajustar los significados, ajustar la vida social: “...En países como el nuestro, una palabra sola, como la falta de una palabra, pueden ser de gran trascendencia en el giro que el mismo pais ha de tomar acaso definitivamente" (Florez, 2001:155).

Dentro de este marco de comprensión se inscribe la concepción de nación. Para Caro "el concepto de Estado es sinónimo de nación, y solo se aplica ese nombre a naciones independientes o a aquellos cuerpos políticos que forman una federación, se rigen por leyes propias y en rigor son repúblicas aliadas. Los Estados colombianos eran soberanos. "(...) Dar este nombre a los departamentos sería una "impropiedad del lenguaje"... "Yo reconozco, señor presidente, la magia de ciertas palabras; pero esa magia no es virtud propia del sonido vacío, sino de las ideas o sentimientos que expresan" (Caro, 1986a:81). Además de ser vacía, esta denominación "Estado" para las divisiones territoriales, no afecta la sustancia, las costumbres, la esencia de las mismas. "El nombre propio es una propiedad, y como una parte del individuo que lo lleva. La denominación genérica siendo común a muchos, no pertenece a nadie, se adquiere y se pierde con los cambios de situación (...) El departamento del Cauca recobrará la denominación que tuvo en la antigua Colombia, sin perder su glorioso nombre histórico" (Caro, 1986a:84).

La pregunta que a continuación sigue es: ¿Cuál es el contenido del nombre propio de Colombia? ¿Qué es lo que hace que la palabra Estado se pueda aunar al nombre Colombia? ¿Qué es eso denominado nación colombiana? ¿Cuál es el contenido de "lo uno y múltiplo" del colectivo denominado Colombia?

\subsection{EL ORDEN CATÓLICO Y LA TRADICIÓN HISPÁNICA}

La personalidad de la nación colombiana, a partir de las pistas que hemos tratado de coligar, es una combinación de idioma, religión y costumbres. Según Miguel Antonio Caro la civilización cristiana es la que recoge el legado cultural hispánico. Esto fue, al tenor del constituyente de 1886, lo que no comprendieron los radicales al leer el legado de los fundadores 
"obsérvese que la tendencias aparentemente federativas que mostraron algunos pueblos en la época de la emancipación, no lo fueron en el fondo, por que no respondían al deseo de conservar una legislación foral, sino al natural desconcierto de opiniones relativo a los límites que debian tener las nuevas nacionalidades; y cabalmente nacía este desconcierto de la falta de limites bien marcados, fuera de los geográficos, en pueblos de una misma religión, idioma y costumbres. Las partes que componen la república nunca fueron, bajo el imperio de la civilización cristiana, naciones organizadas e independientes" (Caro, 1962).

El cristianismo es, según Caro, el elemento unificador de nuestra nación. Esta es una posición común al interior de los defensores de la Regeneración. Para el análisis de este postulado nos acercamos a las miradas que sobre este asunto tuvieron algunos de los intelectuales de la misma: Rafael Núñez (1825-1894). José María Samper (1831-1888); Sergio Arboleda (18221888); y por supuesto Miguel Antonio Caro (1843-1909). Todos ellos fueron defensores de la Regeneración; pero hay distancias entre sus posiciones. Los dos primeros, sobre todo Núñez, están preocupados por encontrar el elemento aglutinador que convoque a la Nación. Para Samper la nación se compone de cuatro elementos: "Un territorio apropiado, como dominio permanente y exclusivo; pueblo sedentario más o menos homogéneo, establecido en aquel territorio, y que domina; un orden institucional que rija sobre aquel territorio de un modo privativo, y regulariza la vida social de aquel pueblo, y un gobierno constituido, entidad más o menos convencional, que dirige y define el Estado, lo representa ante el mundo, y es el lazo de unión y de fuerza entre los asociados" (Laguado, 2004:122). Estos elementos son el resultado de una historia común y permite a los estados insertarse el orden natural de las cosas. Es en la preocupación por la historia común y los elementos unificadores de la misma donde este autor ubica la religión católica.

Núñez, desde una perspectiva más abstracta, también se pregunta por el común denominador de la dispersión estos territorios, esta preocupación por lograr la unidad nacional en una nación heterogénea no es nueva en Núñez, e incluso en sus épocas como federales, buscará un principio de cohesión nacional -ni el único- en los elementos culturales. A estos los llamaba conservadores. Éste elemento conservador garante de unidad es el que Núñez se propone recuperar con la Regeneración y que encontrará en la religión católica. En su mensaje a la Asamblea de Delegatarios ${ }^{11}$, decía:

11 Esta Asamblea de Delegatarios son los encargados de diseñar los parámetros axiológicos de la Nueva Constitución. 
“ante todo la reconstrucción de la nacionalidad, rota desde 1863, por el federalismo, cuando se fraccionó la soberanía de la nación en nueve Estados diferentes, cada uno con su ejército propio, sus propios códigos (...)", (Laguado, 2004:125) Como consecuencia de ello recomendó la adopción de una legislación nacional, con una administración pública igualmente nacional para aplicarla: se establecía el principio de una república unitaria; se reconocía el hecho innegable y protuberante de que la religión católica era la de la mayoría de la nación, y que por lo tanto el sistema educativo de ésta, debía tener por principio "la divina enseñanza cristiana, por ser ella el ALMA MATER de la civilización del mundo” (Laguado, 2004:125).

Mientras los dos primeros, con cierto tinte liberal, están más preocupados por encontrar el principio conservador y/o histórico sobre el que se sostiene la nacionalidad, para Caro y Arboleda esta búsqueda se remite a otros razonamientos; aunque el punto de llegada sea el mismo ${ }^{12}$.

La convicción sobre el fundamento de la nación lo lleva desconfiar profundamente del proceso de integración de los Estados Unidos, que en su constitución permite la libertad de cultos:

"en los Estados Unidos de América se ha llegado a construir nacionalidades con diferentes cultos; pero aún le falta a este hecho la prueba del tiempo: en el poco tiempo que llevan de existencia los resultados están muy lejos de confirmar la teoría indiferentista. Obsérvese que todos alli son cristianos, que reconocen la misma moral y que pueden ser regidos por leyes civiles y penales semejantes, y que, sin embargo, su estado social no es muy lisonjero: la institución de la familia, sin suficientes y uniformes garantías, se va descomponiendo, y los intereses materiales absorben y anulan los sentimientos del corazón” (Laguado, 2004:127).

La crítica apunta a reconocer la diversidad hasta que el catolicismo no sea el dominante. Caro es mucho más radical que Arboleda y pone al sentimiento religioso como elemento en que se funda la nacionalidad.

12 "Para Arboleda, más que un fundamento de unión posible, la religión es la única posibilidad de garantizar el orden; y el régimen federativo sólo será posible cuando se proceda por agregación de diferentes naciones que obtiene ventajas unidas. Pues por encima del proceso histórico - que Arboleda nunca olvida en su análisis- sólo dos bases permitirían el fundamento de las sociedades: la ley natural y las creencias religiosas son el fundamento del orden social y político; porque los principios de la doctrina moral religiosa son la regla de conducta y de las opiniones de los hombres" (Laguado, 2004:126). 
Éste elemento unificador es reconocido expresamente por Miguel Antonio Caro a propósito de una cita que trae a colación; recordando al traductor de la constitución norteamericana en Colombia, Miguel Pombo, que recomendaba "el respeto y la conservación de la religión de nuestros mayores, de esa religión santa que establece el equilibrio entre el débil y el poderoso", pero no advertía que la unidad católica que recomendaba era uno de los muchos rasgos que nos distinguen del país cuya constitución copiaba (Caro, 1990b:354). Además, en la defensa del artículo 38 de la Constitución de 1886 dijo:

"El catolicismo es la religión de Colombia, no sólo por que los colombianos la profesan, sino por ser una religión benemérita de la patria y elemento histórico de la nacionalidad, y también por que no puede ser sustituida por otra. La religión católica fue la que trajo la civilización a nuestro suelo, educó a la raza criolla y acompañó a nuestro pueblo como maestra y amiga en todos tiempos, en próspera y adversa fortuna ... La religión católica fue la religión de nuestros padres, es la nuestra, y será la única posible religión de nuestros hijos" (Caro, 1962:1044).

Este elemento sociológico es que va a determinar de aquí en adelante las características del sujeto, individual y colectivo. El nacionalismo, en Caro, parece asociarse a dos aspectos: "1) una concepción de Estado, en este caso, una república unitaria cuya soberanía reside en la nación, y 2) una concepción cultural, basada en el idioma castellano y en la religión católica" (Sierra, 2002:128). Los que participaban de este nacionalismo eran los elegidos como sujetos políticos, los demás estaban fuera.

Ya dijimos que la instauración del orden católico, como elemento esencial para la unificación, es una de las banderas de la Regeneración. Para Rafael Núñez:

"Constitucionalmente hablando, el Gobierno general debe ser, ante todo, un poder esencialmente moderado y justiciero, toda vez que necesita, a cada instante, del concurso de varios elementos que no sólo no son homogéneos, sino que, de ordinario, divergen en opiniones, intereses y tendencias. Al necesario concierto no puede inspirarse sino inspirando completa confianza a las entidades representativas de tales elementos. Figuran entre ellos, en nuestro país, en lugar prominente, las creencias religiosas; y persuadido profundamente de su gran valor efectivo en el mecanismo social, he hecho considerables y permanentes esfuerzos para establecer con esa fuerza moral y sus autorizados ministros sincera armonía” (Martínez, 2001:454). 
Esta preocupación de Núñez, y en general de la regeneración, es la que delimita los términos de la relación Iglesia-Estado en el marco de la Constitución de 1886 y del Concordato ${ }^{13}$.

Dentro de esta representación de la realidad se puede decir que Caro jugó un papel importante: "Miguel Antonio Caro representa la fidelidad completa y sin reservas a la tradición española, en cuanto ésta significa una concepción típica de la vida personal y la organización del Estado, y en cuanto simboliza una gestión histórica" (Jaramillo, 2001:65). No consideraba superiores los valores anglosajones; por el contrario, siempre defendió la tradición hispánica, "ni el progreso industrial, ni las ciencias, $n i$ el liberalismo económico, ni la sociedad individualista, ni el positivismo, ni el método de las ciencias del espíritu, fueron considerados por Caro como valores absolutos y máximos, y menos aún, como llegaron a considerarlos la mayor parte de sus contemporáneos de Colombia y de América, como objetos de veneración y culto" (Jaramillo, 2001:65). Nunca fue, de parte suya, visto como desfavorable el hecho que de España no haya traído a sus colonias los grandes avances en la ciencia y la tecnología, con las implicaciones que tienen estos en la sociedad y las ideas.

Caro no ve un antagonismo entre el estilo y la personalidad española y la colombiana; acepta el hecho de la independencia como loable, pero no así la ruptura con la tradición por ellos instaurada.

Como veremos posteriormente, la independencia es leída como un brote del antiguo sentimiento español de rebeldía contra la tiranía y el despotismo. Ve Caro la independencia como una respuesta de una personalidad gallarda ante la crueldad. "Caro no buscaba las raíces de la independencia americana como casi todos sus contemporáneos, y como ha sido usual en casi toda la historiografía americana, en la influencia de las ideas de la Revolución Francesa, sino en la tradición española" (Jaramillo, 2001:70).

En este orden de ideas, también debemos resaltar la negación de la tradición cultural indígena: "Todo lo que América posee lo debe a España, por que para Caro lo indígena no parece tener significación en la historia espiritual de las nuevas naciones" (Jaramillo, 2001:69). Esta negación del "buen salvaje" también tiene sus antecedentes en la percepción del territorio. Ya habíamos hablado antes de la importancia de la representación territorial

13 Incluso en el último discurso presidencial de Núñez en 1888 dice que el Concordato es el "alma " de la Constitución. 
y su ingerencia en el imaginario político de Caro; solamente queremos aunar lo antes dicho con la negación del legado indígena que percibe Caro. " $L a$ noción de raza que define Caro es bien sui géneris: el latinista y traductor de Virgilio es, talvez, de todos los autores de este período quien más emplea una expresión que para entonces ya era arcaica, a sabiendas lo arcaica y de que pocos viajeros con pretensiones etnográficas empleaban, la de raza latina" (Cubides, 2002:332) ${ }^{14}$.

Esta percepción de la raza (la común-unión con el legado romano que los Reyes Católicos nos enseñaron) fue alimentada, en parte, por las descripciones que "subsidiariamente" traían las representaciones cartográficas; cartogramas en los que se estudiaba el territorio por las clases dirigentes (más si se asegura que el viaje más largo que Caro hizo por Colombia fue a San Gíl) en el Tratado completo de geografía universal, de, Federico Lleras ( $2^{\mathrm{a}}$ edición, 1874) parece la visión del territorio que entonces se poseía. Allí nos ofrece la siguiente descripción del sistema de cordilleras:

"A la vez que en los valles bajos y en las costas se despliega toda su magnificencia intertropical, extendiéndose sobre los Andes en Pasto y Popayán, y sobre su rama oriental en Bogotá, Boyacá y Santander, inmensas y fértiles planicies, de clima frío y sano todo el otoño, verdaderos Tibets andinos de 2.133 a 3733 metros de elevación sobre el mar, en donde la raza caucásica prospera en toda su belleza y vigor europeos con exclusión de la África que naturalmente busca los valles y la costas ardientes..." (p. 25).

Y una percepción reiterada, contra toda evidencia demográfica y etnográfica, en la página siguiente:

"Los colombianos son reputados generalmente por laboriosos, honrados y hospitalarios, distinguiéndose por sus maneras y cultura literaria la clase educada. Casi todos los habitantes del interior, especialmente los de la altiplanicie, son blancos. Las llanuras del oriente están habitadas por indios independientes. (...) Lo que tiene de significativo el pasaje de Lleras es que no visibiliza el papel del mestizaje y tampoco incorpora en su percepción a los grupos indígenas que habían sido de objeto de descripción de Humbolt

14 “QQué es, pues, eso que así llamamos? Un conjunto de pueblos y familias que se estrechan, confunden e identifican a virtud de una idea, y ésta es la idea católica, comprendiendo bajo el nombre de idea, dogmas, tradiciones y afectos (...) Raza latina es, literalmente hablando, un sofisma. Para que esta frase signifique algo, es preciso tomar las voces en un sentido distinto del que rezan; es preciso interpretar raza por comunión, y latina por romana..." (Cubides, 2001:336). 
(cuyas Cartas americanas habían sido publicadas en francés desde 1865), para no mencionar que de la percepción de la negritud tiene una visión del todo peyorativa" (Cubides, 2002:332).

Retomando el rescate de los principios Hispánicos en Caro, podemos sostener que el nunca aceptó una nación basada en la libertad "absoluta", la desvinculación o atomización social ${ }^{15}$.

Desde luego, en consonancia con lo que venimos afirmando, Caro siempre estuvo apegado a la "cultura española";

"el rescate y la ampliación de la civilización que nos legaron desde la conquista es el ethos de la nación colombiana; en ellos se ha forjado la personalidad de nuestro pueblo. Seamos fieles a la idea española de la vida y sus ideales de honor, magnanimidad, honra, religiosidad y heroísmo, sin tratar de cambiar el núcleo de nuestro tipo espiritual o de mezclarlo con valores que son incompatibles. La tradición española se ha hecho de valores excelsos, superiores a los que han dado vida a otras formas de expresión nacional, y además, es la nuestra" (citado en Jaramillo, 2001:77)

De allí el rechazo a la necesidad de acudir a otras formas y expresiones de pensamiento de otras culturas (como el utilitarismo de Bentham y las ideas de la revolución Francesa);

"para nada tienen, pues, los pueblos americanos que recurrir a otras culturas, a otras naciones en busca de ideas que circularían como cuerpos extraños en el torrente de la tradición en que pueden encontrarlo todo", "deplorable es y lástima profunda inspira la situación de una raza enervada que por el único consuelo hace ostentación de los nombres de sus progenitores ilustres. Pero doloroso también, sintoma de degeneración y ruina, y rasgo de gratitud mucho más censurable que la necia vanidad, la soberbia y menosprecio con que un pueblo cualquiera, aunque por otra parte esté adornado de algunas virtudes, apenas se digna tomar a ver su cristiana y heroica ascendencia" (citado en Jaramillo, 2001:6)

15 "Nunca aceptó la idea de la superioridad de una civilización basada en la técnica, sobre otras, que, como la española, ejercitaba su genio en la creación de valores artísticos, religiosos o metafísicos. A este propósito merece recordar estas palabras suyas: Yo creo, como aquel gran poeta, que vale más el Evangelio que cuantos libros antes y después de él se han escrito; y que el Decálogo, que solo consta de diez renglones, ha hecho más bien a la humanidad que todos los ferrocarriles y telégrafos, y velas y vapores, y máquinas, cuyas resurrecciones, si no invenciones, aprecio como es justo y disfruto agradecido" (Jaramillo, 2001:77). 
2.6. INMIGRACIÓN, RELIGIÓN Y CONSTRUCCIÓN DE LA NACIÓN SOBRE LA BASE DEL LEGADO HISPÁNICO

Estas apreciaciones se ven aunadas a lo que ha denominado Frédéric Martínez: La denuncia de la Europa subversiva. Hay un cambio drástico respecto del referente europeo sobre el cual se remite la Regeneración, y sobre todo nuestro regenerador. Los fuertes remezones políticos y sociales que se surten en los países europeos debido a la amalgama de propuestas y reivindicaciones sociales, siendo las más destacadas las luchas proletarias bajo el influjo del socialismo y el anarquismo, hacen que el régimen de la Regeneración tema la entrada y proliferación de ideas propias de la subversión europea. "Nicolás Tanco, un veterano de la oposición conservadora, quién había optado por el exilio en 1851, amenazado por la violencia de sus diatribas contra el gobierno de López, describe en un fascículo de 1882 la influencia devastadora de la revolución francesa en Colombia:

"La revolución francesa de 1848 tuvo lugar en la caída del conservatismo en América, y los excesos del comunismo en aquella época, empezaron a preparar una nueva escena política en nuestra Patría: el tercer partido de que hemos hablado, el disolvente radicalismo. Las sangrientas jornadas de junio, anunciadas por Luis Blanc y Raspail en París, prepararon el 24 de enero en Caracas, el asesinato del Congreso y el 7 de marzo entre nosotros, que llevó al poder, contra la voluntad del pueblo y sus Representantes, al general José Hilario López. Fue esta administración, desde su origen, una reacción violenta, un desborde terrible de las pasiones políticas que volvieron a traernos la guerra con todo su cortejo de calamidades. Vimos entonces la majestad del congreso ultrajada, perseguidos todos los escritores públicos, atacadas todas las libertades, desterradas multitudes de notabilidades; y si al son de la Marsellesa se cometían en Francia toda clase de atentados, aqui les sobrepujaron, y al chasquido del látigo o perrero, los retozos democráticos llevaban la disolución y el escándalo de un confin a otro de la república" (Citado en Martínez, 2001:432).

El contagio por la decadencia Europea es el resultado, entre otras causas, de la mirada de los colombianos de la época hacia los fenómenos sociales de ciertos países europeos: "la miseria material y moral de la clase obrera, la disolución de los lazos familiares, la delincuencia, la anarquía, el nihilismo, la Comuna, todo es descrito, amalgamado, como un solo y único periodo" (Martínez, 2001:438). Inglaterra y Francia son los dos países a los que se dirige especialmente la mirada. Pero, "menos industrializada pero más revolucionaria, Francia es, en última instancia, la que más encarna para 
las élites colombianas la quintaesencia del mal europeo y el arquetipo de la corrupción moral” (Martínez, 2001:438).

El miedo a la muchedumbre y a la atomización social se refleja en la concepción que se tiene de la Comuna de París. La mayoría de los componentes de las élites ven el suceso como la actividad de comunistas y malandrines: "sólo Núñez reflexiona sobre las verdaderas causas de la Comuna que escribe desde Liverpool, que no era un saqueo brutal lo que se proponian la insurrección, sino la realización de la preponderancia del interés de los obreros en sus relaciones con el capital" (Martínez, 2001:439). Pero pese a ello, su visión sobre la forma en que los dirigentes de la comuna realizan el poder dice: "para las multitudes ella (la dirigencia) aparece con frecuencia como aliada de crueldad o de persecución; como emblema de ira y venganza más que de protección y consuelo" (Martínez, 2001:439).

Otro fenómeno que ayuda a que el desprestigio y la decadencia se monten sobre la percepción de Francia, tiene que ver con los atentados anarquistas que fueron mayores en número y en tenacidad en París de la década de los ochenta del siglo XIX. "El asesinato del presidente francés Sadi-Carnot, relatado con lujo de detalles por los periódicos colombianos, confirma la magnitud de la subversión francesa" (Martínez, 2001:444). La unión de este imaginario con categorías como Francia, Revolución francesa, liberalismo radical, anarquismo y libertad de prensa; es utilizada por Caro para señalar a los que aquí se denominan des(con)centrados ${ }^{16}$.

La Comuna y el anarquismo se aúnan con la percepción de inmoralidad, prostitución, adulterio y suicidio ${ }^{17}$.

"La imagen de París como una nueva Babilonia, ciudad de placeres, vicios y corrupción, inspira durante todo el siglo XIX el imaginario colombiano (...) Mas allá de los efectos retóricos de Miguel Antonio Caro, la gran atención dada por la opinión pública de la época al peligro social europeo nace de la convicción de que la subversión se puede trasladar en poco tiempo a Colombia: los ideólogos de la regeneración persuaden a sus compatriotas de que la influencia subversiva

\footnotetext{
16 Ver el aparte que se dedica a los descentrados o des(con)centrados.

17 Recordemos que para Caro el suicidio es sinónimo de instinto que acompaña a los descentrados o carentes de personalidad. Según Caro, esta necesidad es una fatalidad de la cual, en algunos momentos, intentamos abandonar. "Aquel placer que experimentamos cuando nos perdemos incógnitos entre la muchedumbre, nace del deseo de extraviar nuestra personalidad". "Finalmente, el que resuelve levantarse la tapa de los sesos, trata de disolver el grupo importuno que constituye su personalidad".
} 
europea se advierte ya en Colombia, en las explosiones de cólera popular, en las conspiraciones políticas y en la propagación del suicidio y la prostitución (...) Los dirigentes creen ver una prueba inequívoca de la difusión en Colombia de los ideales y de los medios de acción de la Internacional Socialista en la utilización de una referencia europea alternativa-aunque fundamentalmente simbólica-en las revueltas populares". (Martínez, 2001:444) ${ }^{18}$.

Este temor a la contaminación de la decadencia europea también se expresa en el miedo a la inmigración de personas del viejo continente ${ }^{19}$.

Curiosamente Colombia no fue un lugar potencial para los inmigrantes europeos, aun durante la época de gobierno de los radicales, y sin embargo fue uno de los primeros países Latinoamericanos en formular leyes antiinmigracionistas.

Pese a que la retórica de la época fue reticente a la importación de ideas y a propinar la inmigración, la regeneración ve en Inglaterra y España los referentes europeos. Según el autor que venimos referenciando, son dos las razones que llevan a esta preferencia: por un lado están la experiencia y preferencia personales (Rafael Núñez residió cinco años en Liverpool, Carlos Holguín fue nombrado ministro en Londres; y junto con Caro todos eran admiradores de España). El otro elemento es el relativismo institucional de ambas coronas.

"Inglaterra es, sobre todo, el país donde el espiritu liberal está contrabalanceando por la necesidad del orden (...) La valiosa combinación de la libertad y el orden, de estabilidad y progreso que caracterizan la vida política inglesa ha comenzado a difundirse por toda Europa (...) otorgándole así cierta unanimidad al lema del liberalismo conservador reivindicado por la Regeneración”. (Martínez, 2001:452).

También se convierte en el referente de una nación civilizada que se contrapone a la desestabilizad política que vive Francia. España había

18 Retomaremos este aspecto en el acápite final sobre la "cuestión social” en Caro.

19 "Durante una misión diplomática a Uruguay en 1884, José María Samper anota que la inmigración es un fenómeno natural, querido por Dios, pero que acarrea una seria amenaza social: "También contiene las inmigraciones extranjeras, en los pueblos nuevos, como en los americanos, un gran peligro: el de comprometer la unidad nacional del pueblo que las recibe (...) Si no se adoptan los correctivos eficaces, un pueblo joven puede perder, dominado por la ondas de los inmigrantes extranjeros, lo más noble i lo más íntimo de su ser colectivo: su espíritu nacional y su lengua" (Martínez, 2001:448). 
salido desde la época de la independencia del imaginario político y de la preferencia de los viajeros colombianos, pero esta situación comienza a cambiar al rededor $1870^{20}$.

Los intercambios entre Colombia y España fueron intensos en el campo de las letras y del intelecto; sin embargo, en la adopción de las instituciones no fue muy significativo; solo se dieron: "unos intercambios embrionarios en el campo militar, unos vanos intentos de importación de agricultores ibéricos y la llegada de algunas congregaciones constituirían todo el aporte España al proyecto político de la Regeneración" (Martínez, 2001:461). Aun así el aporte más significativo se encuentra dentro del orden de la educación y la instrucción pública.

\subsection{El HOMBRE PÚBLICO COMO ARQUETIPO. LA PASTORAL CRISTIANA}

La pretensión de uniformidad moral y lingüística cristaliza para Caro en la correspondencia simétrica entre la nación y su mandatario, semejanza que restringe tanto al Hombre de Estado como a su pueblo las posibilidades de acción, quedando la praxis discursiva de ambos co-implicada en un código moral único. Se determina así la identidad entre gobernantes y gobernados: "La identidad de creencias del funcionario y de la nación puede establecerse de dos modos: o el funcionario para serlo ha de creer lo que la nación cree, o la nación ha de someterse a los caprichos del gobernante. Aqui ha querido practicarse la identidad en la segunda odiosa e injustísima forma: por cuanto ciertos hombres públicos eran ateos" (Caro, 1962:1245).

Precisamente a esos hombres públicos ateos era a los que se refería en la citada alocución, dejándolos por fuera de los cargos públicos, por fuera del debate político; ellos no podían hacer parte del cuerpo político del Estado (sinónimo de nación).

"los anarquistas y los reaccionarios son enemigos del gobierno, no por otra razón, sino porque contrarían el bienestar social; y el gobierno los excluye del

20 "Los avatares de la revolución española, el movimiento federalista que libera, los debates que rodean la Constitución de 1869, los tropiezos de Amadeo de Saboya y la proclamación de la Primera República en 1873 contribuyen a reanimar la curiosidad hacia la antigua metrópoli, a darle una nueva pertinencia en la vida política Colombiana (...) El término de república autoritaria utilizado por Caro para designar la Regeneración remite al mismo calificativo aplicado, en 1874, al viraje conservador de los últimos meses de la Primera República española” (Martínez, 2001:456). 
servicio público, no por lo que fueron, sino por lo que son; no por odio político, sino por ejercicio de aquella instintiva e impasible intolerancia con que todo organismo excluye y desecha los elementos destructivos de su existencia" (Caro, 1990b: 297).

Aparece claramente la tentativa de naturalizar, por la vía de las metáforas biológicas, la expulsión de toda resistencia política al gobierno, apelando a una larga tradición, que por lo menos desde Platón en "La República", pasando por la retórica de los Estados totalitarios en Europa en la primera mitad del siglo $\mathrm{XX}$, equipara el cuerpo social al cuerpo de un organismo vivo, permitiéndose así la comparación incuestionable entre los opositores al régimen imperante con la enfermedad y los agentes patógenos.

Esto se conecta con el desdoblamiento, múltiplo no múltiple, de la personalidad. El representante de la nación deber profesar el credo de ésta. La nación eligió el régimen regenerador, luego este es que el deben profesar los que a ella sirven, esta es la condición del hombre público; su nombre público, ya no es, por ejemplo, Caro, sino el Regenerador. En la respuesta a una consulta acerca de su opinión sobre la designación de candidatos para unas elecciones dice nuestro autor que más que designar los hombres o nombres, prefiere caracterizar los perfiles de las personas que ocupan los escaños públicos; "ningún interés tengo en que vengan al congreso determinadas personas, pero si, y muy vivo, el que concurran hombres de muy buena voluntad, penetrados del espíritu de la regeneración, que tengan el valor de sus convicciones y sepan defender la causa que a salvado el país" (Caro, 1991:4). Él se considera, en su condición de estadista, un "hombre público" que no tiene amigos personales; en esta condición solo reconoce como amigos a los leales servidores del proyecto regenerador. "Como hombre público, no tengo amigos personales, sino políticos, y considero tales, cualquiera que sea su nombre y procedencia, a los leales amigos de las instituciones". Es importante destacar aquí cómo para la Ciencia Política la evolución del poder político avanzaría de unas relaciones de fuerzas difusas, impersonales, hacia modelos de poder personalizado, centralizado en un líder, para acabar en una organización institucionalizada, que prescinde de los sujetos particulares en favor de la generalidad abstracta de la Ley como fuente de toda autoridad (Echeverri, 2002:74). Tal como la Teoría del Estado se mueve entre unas poliarquías policéntricas y diseminadas, propias del medioevo en Europa, hasta llegar a consolidar un Estado de Derecho o incluso un Estado Social de Derecho a lo largo del siglo XX (Echeverri, 2002:111). 
El desdoblamiento de la personalidad también tiene fundamento en la concepción que Caro tiene sobre el origen de la soberanía. Para él Dios es el soberano absoluto, rey de reyes; las autoridades son un gobierno temporal que se instaura para continuar la autoridad de Dios en la tierra. El hombre constituido en autoridad es un maestro aleccionado por otro maestro superior. Dios es Rey de reyes. El "dicta la ley universal, la enseña a la razón (esta ilustración es lo que llamamos ley natural)” (Caro, 1962:141). Este representante de Dios en la tierra no crea derechos; su misión o deber es el de "promoverlos, armonizarlos ... O como dice atinadamente el abate Rosmini, la ley positiva no establece el derecho sino la modalidad del derecho" (Caro, 1962:142). Con lo anterior es fácil ver que este modelo de Estado no se inscribe en la noción de Estado Moderno, que desde Maquiavelo se perfila como una esfera de poder secular, en la creación de un espacio "público" claramente diferenciado del "privado"; para decirlo con palabras de Hardt y Negri, El Estado establece un plano de trascendencia que conjura el poder inmanente, autocreativo y constituyente de la "multitud" (HardtNegri, 2001).

La autoridad en la tierra, para Caro, no hizo sino especificar los contenidos inmutables de la Ley eterna; lo que equivale a defender las costumbres de una nación cristiana, el rescate del sueño de los fundadores de la misma:

"Si volvemos los ojos a los comienzos de nuestra última transformación política, encontraremos como documento fundamental la exposición que el presidente de Colombia dirigió al Consejo Nacional en 1885. Allí, con valor heroico para aquellos tiempos, proclamase la "república autoritaria", la unidad legislativa, la concordia entre la iglesia y el Estado, la enseñanza cristiana, la moralización de la prensa, la devolución al gobierno de sus facultades naturales, ... No fueron otros los principios que el Libertador de Colombia recomendó ya con voz falleciente a nuestros padres" (Caro, 1991:14-15).

Podría hablarse de una tensión entre MODERNIZACIÓN y MORALIZACIÓN del proyecto hegemónico Regenerador; donde éste último vector cobra una relevancia inusitada al constituirse como eje de las políticas públicas, postergando la implantación de relaciones de dominación propias de un Estado de Derecho secularizado hasta el primer cuarto del siglo XX.

Una consecuencia de ello es la fortaleza e irresponsabilidad del padre político. Un fuerte pensamiento de excepción embarga el pensamiento de Caro. Él es partidario de la institución romana de la dictadura "como medio constitucional de salvar y asegurar la libertad". 
De otro lado, la persona que representa al Estado, al no tener como superior más que a Dios, es solo ante Él responsable. Sosteniéndose entonces, que el presidente en términos generales y abstractos sí debe responder porque en general todos los hombres, "como criaturas racionales y libres, estamos obligados a algún género de responsabilidad, sin la cual no se concibe la justicia de Dios" (Caro, 1986a: 142). El presidente, por ser la cabeza de todos los poderes, está por fuera de la justicia humana ${ }^{21}$.

Así las cosas,

"la responsabilidad política termina, por razón de impotencia o por motivos de prudencia en la cúspide de todos los poderes públicos, y aquellos políticos que discurren en el engranaje de tales responsabilidades, que la justicia haya de hacerse completa sobre la tierra, y por ley humana, y nada haya de dejarse al tribunal de la conciencia ni al de Dios, sólo dan muestra de estar poseídos de satánica soberbia, la cual suele despeñar a pecados vergonzosos; $y$ sus sistemas de gobierno dan comúnmente frutos contrarios a sus promesas, engendrando a vueltas de universal justicia, la general indulgencia y la completa impunidad" (Caro, 1986a: 148).

En este orden de ideas, y como jefe de la república, Caro fue el continuador de la construcción del imaginario de la Regeneración al interior de las personas; su labor fue la de educar a la población; al fin y al cabo para el "Gobernar es educar" (Caro, 1962; 141). Esta tarea fue la que trazó desde el principio de la labor como encargado de las riendas de Estado: "realizada la gran reforma, hemos entrado en el periodo que obliga conservar los bienes adquiridos y desenvolver los gérmenes fecundos... Hemos reformado las leyes; nos cumple ahora atender a la reforma de los hombres, de nosotros mismos, por la educación en el respeto de las cosas serias, por la práctica de mayores virtudes" (Caro, 1991:16). Subrayado fuera de texto.

Esta labor la lograría con cuatro elementos: 1 . Alejar a los descentrados de las esferas del poder; 2. Quitar la máscara, la posibilidad de hablar, la Voz

21 Si la identidad conlleva una cierta permanencia en las opiniones, si el carácter consiste en unos rasgos que se mantienen inalterables, entonces hablar descontroladamente es un reto a la organización modulada de los discursos: "Ese sentimiento bueno [hablar reprimiendo los deseos] solo pudo cobrar carácter de orgullo, que es especificamente narcisista, luego que la autoridad misma hubo devenido parte del yo. (...) Se puede decir justamente que ese gran hombre [Caro en éste caso, o Moisés para la religión Judaica] es la autoridad por cuyo amor uno consuma el logro, y puesto que a su vez él ejerce una acción eficiente merced a su semejanza con el padre, no cabe asombrarse de que en la sicología de las masas le corresponda el papel del superyo. ( FREUD, 1984:13). 
a los descentrados; 3. Permitir que la institución que traza doctrina sobre la verdad, La Iglesia, se encargue de seguir construyendo la civilización cristiana. 4. Endurecer al Estado, y a sus representantes, para que a través del derecho penal se aplique la medicina a los males del alma.

Empecemos por caracterizar a los des(con)centrados. El descentrado es aquel que no tiene idea ni conoce el deber; es aquella persona que se guía por los instintos y/o que busca la satisfacción propia. Este un hombre que lo mueve la pasión y "la pasión no existe en la región intelectual" (Caro, 1962:65); luego el hombre que por ella se guía es un bruto; porque "en efecto ¿no es evidente que el bruto no piensa?” (Caro, 1962:277).

Estos descentrados, son los que siguen la doctrina utilitarista.

"Y, sin embargo, hay quienes niegan la ley natural (la razón como dijimos antes). Los utilitaristas la niegan, como hemos visto. Admitida esa negación, la conducta humana presenta el carácter de irracional y fatal no solo en sus manifestaciones privadas, sino en las sociales. Si el hombre no es otra cosa en su esencia, sino un animal que maquinalmente busca el placer y huye al dolor, ¿cómo puede elevarse a la idea de una sociedad espiritual y culta? ¿Cómo con elementos brutos ha de poder constituir un todo racional? El utilitarista, que solo considera asi al individuo, no puede considerar la sociedad bajo un concepto más noble sino incurriendo en contradicción con sus principios". (Caro, 1962:142).

Dentro del cuerpo social, estos elementos son los revolucionarios, anárquicos o tiránicos, que no comparten el elemento integrador de la nación, la religión católica.

"Hay, pues, politicamente hablando, dos facciones de utilitaristas: los unos adoran el placer, los otros rinden humildes homenajes a la fuerza. Aquellos son los utilitaristas ortodoxos, éstos disidentes. Aquéllos viven reñidos con la sociedad, son eminentemente revolucionarios; éstos, eminentemente serviles. Aquéllos no quieren ni aun la ley; estos no quieren más ley que la fuerza. Aquéllos niegan a Dios; éstos apellidan dios a un satánico. Pero tienen un templo común: el del ateísmo; alli fraternizan cordialmente" (Caro, 1962:145).

Estos descentrados, cuando se presentan como oposición, según los describe Caro, como una "colectividad monstruosa", constituyen un verdadero Leviatán. Una vez establecido el proyecto regenerador por el pacto constitucional, la fracción vencida en 1885 "acarició el sueño del desquite". En aquel anhelo se estableció una organización que "no satisfacía a los propósitos de unidad de acción y vigorosa disciplina; una junta intitulada 
congreso, legítimó con aplicación a un partido político, individualista en principios, cierta forma despótica rechazada por los más autoritarios en la organización de los poderes públicos, y estableció una dirección unipersonal con poder absoluto para dogmatizar, levantar contribuciones y decretar la paz o la guerra" (Caro, 1991:93). Por lo cual "el partido reaccionario se compone de una masa revolucionaria y en parte enérgica, de algunos políticos doctrinarios, especie de sacerdotes de una religión muerta, y de gente laboriosa y pacifica, y aun propietarios ricos, que por vínculos tradicionales, o por motivos imaginarios se consideran ligados a una causa que no se sabe si aman más que temen" (Caro, 1991:93).

De los predicadores de esta doctrina de falsos ídolos es que hay que salvar a la población Colombiana, que es una población altamente vulnerable y susceptible al engaño. Ya lo anticipábamos en el párrafo anterior, pero queremos hacerlo más explícito. Caro ve las grandes masas de población como un rebaño a las que el Estado pastor o educador (más no docente, como lo veremos más adelante) tiene que conducir, implementando un verdadero "poder pastoral" en la terminología foucaultiana, vale decir, dando lugar a un tipo de dominación caracterizado por la intromisión salvífica del "pastor", "hombre de Estado, "buen padre de familia" etc., en lo más recóndito del pensamiento de su rebaño, de tal suerte que la sujeción se logra penetrando el alma de los súbditos, conduciéndola, guíandola a una meta extra-discursiva y ultra-mundana, cuya inconmesurabilidad es la que garantiza que solo a través del Mesías -o un representante- como director de consciencia o maestro espiritual, se alcanza la anhelada meta. Dispositivo de control que el filósofo francés rastrea a partir de la civilización egipcia, encontrando desarrollo en la religión judaica de acuerdo a la influencia de patriarcas tan poderosos como Moisés, todos ellos simbolizados como pastores. Resulta interesante entender el modo a través del cual este modelo es recreado por la Iglesia Católica en los primeros años del cristianismo, hasta convertirse durante la edad media en una práctica sumamente sofisticada, en la cual el clero cumple el papel de guía espiritual al establecer ritos como el sacramento de la penitencia, en donde la obligación de expresar los movimientos anímicos más pequeños, las inclinaciones, las tentaciones incipientes, hace parte de una forma de auto-vigilancia de los individuos. El agenciamiento pastoral alcanza su máxima expresión con la creación del imaginario del purgatorio y el infierno, así como en la ceremonia expiatoria del acto de contrición en la eucaristía, o en la necesidad de purificación de los pecados, todo lo cual, en síntesis, atenaza en la jaula de la consciencia la más mínima desviación 
a la norma, entregando el devenir sensible del cuerpo a la inmisericorde mirada de un Otro que no admite errores, ni dudas con relación a la salvación. Así Caro, especialmente en los textos que reseñamos, se erige en un gendarme celoso de las creencias del catolicismo, permitiéndose así una estricta y disciplinante incursión en los pensamientos de su grey, elaborando esos pensamientos, como parte de un proceso de generación de la culpabilidad ${ }^{22}$ que de modo incesante constriñe la sensibilidad en un trabajo de Sísifo, delirante, recomenzado; extrayendo del remordimiento y de la falta original, condiciones de una pureza siempre en entredicho, amenazada infinitesimalmente incluso contra la voluntad de los pecadores, haciendo posible la masificación de una moral de rebaño que Miguel Antonio Caro ejemplifica magistralmente en el último recodo del siglo XIX en Colombia, cimentando, a la larga, todo un molde para la elaboración de la subjetividad, para el auto-conocimiento de las personas, dentro de los límites discursivos de un armado conceptual ominoso, opresivo hasta lo indecible, instalado en los criterios mismos de interpretación de los datos sensibles, en el diseño mismo de la mirada, como puede leerse en las elocuciones de Caro que se han extractado; incluso hasta el modelo panóptico que hace de toda la sociedad una gigantesca, omnipresente e imperceptible jaula de auto-contención de la corporalidad ${ }^{23}$.

22 Existe una excelente genealogía del concepto de Persona en Occidente en "El hombre culpable", trabajo que desde el sicoanálisis revela el armado de una consciencia siempre culpable, estructura básica del aparato síquico del hombre Occidental, Pewzner Catherine, F.C.E. México, 1996.

23 Tratamos aquí de especificar las alusiones teóricas hechas en la primera parte de este trabajo. Sobre el poder pastoral, ver Foucault M., Las tecnologías del yo, esp. la conf. Omnis et singuilatim, Barcelona: Paidós, 1997, en la que se discurte la imbricación de la tecnología de poder pastoral que hemos tratado de bosquejar aquí con otra distinta técnica de dominación: el dispositivo de ciudadanía, que proveniente de Grecia, aseguraría por otros medios la fabricación de los cuerpos dóciles. La mezcla de ambas estrategias de identificación formaría al Estado Moderno, simultáneamente singularizador (individualizador) y masificador (totalizador). Hemos tratado de potenciar estas reflexiones conectando la elaboración de la Identidad colectiva "Nación" bajo el significante despótico "República de Colombia" ocurrida con la expedición de la carta política de 1886, con la producción de la Identidad individual "persona", dentro del régimen normativo de condensación del Sujeto Jurídico, contenido en el código civil adoptado en 1887 . Sobre el panóptico son muy conocidos los análisis de Foucault en la cuarta y quinta conferencias de "La verdad y las formas Jurídicas", (1990). Así como las aproximaciones al nacimiento de la prisión en "Vigilar y Castigar", (1987). La última parte de la obra de Foucault gira alrededor de la problemática de la interpretación de sí en obras como la historia de la sexualidad T. II (1992), El uso 
Desde este punto de vista la minoría de edad es el factor que permite homogenizar la invalidez mental intrínseca a la población colombiana, haciéndola necesitar de un lider para sobrellevar su inmadurez moral congénita, táctica que, creando previamente una atmósfera de zozobra y miedo a la condenación eterna, conduce a la aceptación irreflexiva de una autoridad que brinde un soporte estable, una institucionalidad legitimada en el diagnóstico catastrófico de un estado de cosas irremediable, generando y posteriormente administrando la sensación colectiva de ingobernabilidad.

En este ambiente, el gobernante-pastor dedica una especial atención a la juventud, en la medida en que nuestra raza se caracteriza "porque ha conservado en América muchas buenas cualidades, templada la dureza de su carácter por la influencia del cielo y la mezcla la raza indígena. Nuestro pueblo no es rapaz ni feroz" (Caro, 1990b:47).

A estos descentrados, obligados a ser guiados, se decide quitar la herramienta más importante que tienen para expandir su doctrina; la voz. Son seres que susurran ${ }^{24}$, que hacen ruido pero que no pueden transmitir palabra ni idea alguna. A ellos se les cortó la voz, ya no pueden articularse; ya no publican, ni educan (gobiernan). Una de las más arduas luchas de Caro como presidente encargado fue defender las leyes de restricción de imprenta y prensa, materializando así la condenación de las voces disidentes al silencio o al sinsentido. Va a sostener el regenerador bogotano que la Libertad de Prensa es uno de los instrumentos de los nihilistas (rebeldes y/o anárquicos) para derrocar al gobierno. Frente al atentado del General Aldana dice: Andrés López (uno de los generales detenidos que no había sido puesto en libertad). "no alimentaba contra el General Aldana odios ni rencores personales que puedan explicar el crimen; Andrés López aparece en íntimas relaciones con hombres de malísima reputación a quienes la Salud Pública ha recibido y abrigado en su seno" (Caro, 1990b:49); frente a esto se pregunta: “ ¿Se ignora por ventura el contagio ${ }^{25}$ de las malas ideas

de los placeres y T. III. La inquietud de sí, 1992. Recientemente se han publicado las conferencias del College de France correspondientes al año 1981-82 tituladas la hermenéutica del sujeto, (2004).

24 "Cuando uno jadea o sopla, el aire que expira es solo aliento, y más bien que sonido produce ruidos. Cuando uno habla o canta, el aire hace vibrar los ligamentos llamados cuerdas vocales, y produce verdaderos sonidos. Voz es ese aire sonoro mezclado con algunos ruidos de que se acompaña para formar palabras". (Caro, 1980:332).

25 Cursiva fuera del texto. La pretensión de este trabajo, en términos generales, es hacer una observación de segundo orden sobre las actuaciones verbales de Miguel Antonio 
y la eficacia funesta que suelen tener en tiempo de agitación los papales incendiarios?" (Caro, 1990b:49).

En la defensa del artículo 42 y del artículo transitorio K (letra con que los antiguos romanos marcaban a los calumniadores) de la Constitución de 1886 sostiene: "por que es derecho natural el deber legal de reprimir todo abuso, y siendo la prensa un instrumento, como hay otros muchos, que lo mismo sirve para hacer el bien que el mal, no se concibe que solo por el contacto de este instrumento, aunque especial, los actos humanos más detestables hayan de adquirir la naturaleza de buenos o de indiferentes" (Caro, 1991:101), para luego añadir: "el sistema preventivo que ese artículo autoriza consiste en poder impedir una publicación, o sea en el ejercicio de la previa censura"; precisamente para evitar "la confabulación que se preparaba en contra del gobierno" (Caro, 1991:103). Este artículo transitorio desata una fuerte polémica, y a su vez es la base por la cual se dicta el decreto ejecutivo 151 del 17 de febrero de 1888. Luego, a finales del mismo año se expide la ley 61, por la cual se concede al Presidente de la República facultades extraordinarias para reprimir los delitos y culpas contra el Estado que afecten el orden público. La combinación de estas dos legislaciones dan un fuerte poder de veto al ejecutivo sobre a la opinión

Caro implicadas en las actuaciones verbales que fabrican este mismo trabajo, es decir, se busca no solo revisar las fuentes primarias a partir de criterios de inteligibilidad ya dados, sino someter a observación esos mismos criterios, profundizar en una dimensión Meta-histórica acerca de los modos como nuestro personaje teje el relato de los hechos y por lo tanto configura una visión del pasado. Ésta narración requiere del uso de un espacio preconceptual sobre el que se van a disponer los acontecimientos, considerando que esta es la diferencia con el enfoque historiográfico de la Historia Social o socio-cultural, como quedó reseñado en el primer capítulo. Este espacio preconceptual es un molde históricamente constituido que otorga sentido a los eventos: "el problema del historiador consiste en producir un protocolo linguistico completo, con dimensiones léxica, gramatical, sintáctica y semántica, por el cual caracterizar el campo y sus elementos en sus propios términos (antes que en los términos con que vienen calificados en los propios documetos), y así prepararlos para la explicación y la representación que después ofrecerá de ellos su narración. Este protocolo lingüístico preconceptual a su vez será -en virtud de su naturaleza esencialmente prefigurativacaracterizable en términos del modo tropológico dominante en que está expresado". White, Hayden, Metahistoria, F.C.E., México, 2001, p. 40. Podríamos sostener que la metáfora constituye en Caro el tipo de tropo que como una clave dominante hace comprensible su versión sobre los acontecimientos. En tanto estrategia de persuasión la constante equiparación de las ideas liberales a una enfermedad virualenta, altamente contagiosa, podría verse como un intento por fabricar un horizonte de legibilidad a sus propias afirmaciones. 
pública que sujeta cualquier opinión disidente. Caro defiende esta posición sustentando su posición en la recta comprensión de la libertad. Según su parecer, el liberalismo es:

"aquel sistema político que por no distinguir en el orden moral y dogmático lo bueno de lo malo, lo verdadero de los falso, concede al bien y al mal, a la verdad y al error, unos mismos derechos sociales (...) El liberalismo (...) declara en teoría que toda opinión, toda doctrina, cualquiera que sea, tiene derecho a manifestarse y propagarse, sin restricción ninguna por todos los medios de publicidad; y como de todos éstos es la imprenta el más eficaz y poderoso, la libertad absoluta o irresponsable de imprenta ha venido a constituir el principio fundamental, o capital aplicación, del liberalismo" (Sierra, 2001:226).

Frente a este principio de irresponsabilidad que Caro ve en el concepto de Libertad de prensa trazado por los liberales, se propone y defiende la teoría cristiana de la responsabilidad ${ }^{26}$ que se establece en la posición del ejecutivo.

El reconocimiento de la nacionalidad a partir de la iglesia cohesiona estos pronunciamientos a la vez que refuerzan su carácter de dogma. Lo que busca con esta censura es evitar el descentre de la patria; por ello condena la comparación con otras Naciones en donde no existe esta privación (una comprensión fuera de si, como el bruto). "Bien se comprende que en aquellas naciones en donde ni existe el peligro de las guerras intestinas, ni hay esfuerzo periodística capaz de provocar un levantamiento" (Caro, 1991:107).

La educación es una labor de la iglesia, para la regeneración la labor del Estado como educador se extinguió. La Regeneración entrego la instrucción pública a la Iglesia. La educación era un elemento importante para instaurar el orden y como elemento de cohesión social; por ello la educación debe soportarse sobre la base de la nacionalidad ${ }^{27}$. El problema, en este orden de ideas, se centra en un aspecto más fundamentalista. El Estado, aunque educa, ni puede ni debe ser docente, porque el no tiene el derecho ni sabe definir:

\footnotetext{
26 Ya que, como se verá más adelante es esta libertad en fundamento mismo de la noción de persona, el carácter exigible de su conducta.

27 "Todas las naciones, y con particularidad aquellas que han hecho un cambio fundamental en su Constitución política, deben dar a los pueblos una educación uniforme sobre un plan sistematizado y constante, hasta imprimirle el sello de las nuevas Constituciones. La educación no puede tener otras bases que la moral religiosa, que lo es también del orden social (...) para Samper la instrucción primaria sólo era buena en caso de ser dirigida conforme al sentimiento y a la necesidad práctica del pueblo colombiano" (Laguado, 2004:145).
} 
"El que enseña, o enseña la verdad o enseña el error o enseña la duda, no hay medio; ahora bien, la verdad es un bien, el error y la duda son males" (Caro, 1862:1339). Esto no hace que el hombre que enseña no cometa errores, lo que no puede es, sabiendo que no produce la verdad, enseñar. "El que profesa un error de buena fe creyendo profesar la verdad, enseñando el error hace el mal, pero su buena intención lo disculpa. Pero el que no teniendo certeza de poseer la verdad impone a una generación una doctrina, ¿qué disculpa puede alegar?” (Caro, 1862:1339). Esta doctrina es el utilitarismo.

\subsection{EDUCACIÓN Y GOBIERNO}

Pero si el Estado, según se ha comprobado en el acápite anterior, no puede profesar ni proferir ningún tipo de verdad; ¿Por qué "Gobernar es educar”? Para entender este enunciado es necesario comenzar por hacer referencia al "fin de la sociedad" que predica Caro. Tiene una visión que se contrapone a la de Hobbes, es decir, no ve como fin de la sociedad ${ }^{28}$.

En Caro se denota una mayor fuerza y aproximación a las ideas de Montesquieu. Considera que "la familia, la tribu y el Estado constituyen, en cuanto fuerzas sociables, la repuesta a la necesidad de organización impresa en el corazón del hombre, y que lo lleva a perfeccionarse por la asociación. Solitario el hombre es débil, impotente; asociado se hace poderoso, rey verdadero de la tierra" (Valderrama, 1961:178). En el centro de la naturaleza humana se encuentra su inclinación gregaria. No se concibe al hombre como lobo para el hombre; por el contrario, se cree que este enunciado falsea la superación de los instintos por medio de la educación.

Más adelante hablaremos de la distribución de la actividad educadora; bástenos por ahora decir que el gobierno "debe asumir un carácter más bien paternal que administrativo; son distintivos de aquel carácter, en lo visible y material, la antigüedad, la fuerza, la permanencia, pero el amor es el atributo esencial" (Valderrama, 1961:180). La actitud paternal de los gobiernos se manifiesta en la propensión que tienen a educar en y con el amor. El Padre

28 "El cuidado de su propia conservación (la del hombre) y, por añadidura, el logro de una vida más armónica; es decir, el deseo de abandonar esa miserable condición de guerra que ... es consecuencia necesaria de las pasiones naturales del hombre, cuando no existe poder visible que los tenga a raya y los sujete, por temor al castigo, a la realización de sus pactos y a la observancia de las leyes de la naturaleza". (VALDERRAMA, 1961:178). 
ha expulsado del paraíso al hombre, pero no lo ha abandonado; luego envía a su Hijo (el Verbo) para que lo redima; parece ser este el mensaje de Caro.

La labor de la autoridad pública queda entonces determinada por esta misión. Lo que hace la autoridad terrena es reforzar las ideas innatas de justicia y rectitud que ya se encuentran en el hombre y en la naturaleza por medio de la presión en vez del castigo. "El pensamiento de Caro no deja, sin embargo, de ser equitativo en la concreción precisa de la misión del poder público: previsión antes que castigo debe ser el lema de la autoridad constituida. Es una consecuencia lógica de la concepción del poder público como perfeccionamiento de la educación natural" (Valderrama, 1961: 181).

La labor del Estado es más bien policiva que de verdugo; lo que busca es "más bien anunciar mediante dolores prohibitivos un mal, que infamarlo, una vez ejecutado, mediante dolores simplemente instructivos (...) la autoridad pone la pena antes de perpetrar el delito, en el temor de sufrirla; pone el goce ofrecido a la virtud, en la esperanza de obtenerlo" (Valderrama, 1961:182). Así las cosas, este castigo no puede ser obra del arbitrio de los gobernantes de turno sino una manifestación de misericordia para los que se han extraviado por el sendero del mal: "el ejercicio del poder público no es el ministerio del terror, sino una grande obra de misericordia" (Valderrama, 1961: 182).

La arbitrariedad no tiene cabida en el constructo teórico de Caro, esto debido a dos cosas: a) ya hemos dicho que los gobernantes tienen que estar inspirados necesariamente en criterios cristianos; y b) La ley humana no es más que una modalidad de la ley natural. Conectado con la no arbitrariedad del poder, encontramos la medida en que debe aplicarse el castigo preventivo. "La perfección o imperfección de los asociados pide un grado mayor o menor de fuerza en la autoridad gobernante. Por que los justos, los que han alcanzado un mayor grado de perfección, no son en realidad gobernados sino que reinan con Cristo" (Valderrama, 1961: 201).

De otro lado, estas, entre otras razones, son las que lleva a Caro a apartarse del utilitarismo de Bentham y de Hobbes:

"la anulación de la ley natural, exigida tan radicalmente por los secuaces de Bentham, abre una inquietud alternativa: o el derecho, como quiere Hobbes, es la libertad omnímoda del hombre, o, tomando como palabra, no es ni significa nada. La primera solución lleva a la concepción de la ley positiva como violatoria de todo derecho, la segunda hace la ley positiva un hecho sin sentido moral alguno" (citado por Valderrama, 1961:184). 
La disyuntiva planteada por Caro, el apego o no de la ley positiva a la ley natural, amerita sólo dos soluciones:

"o se admite el imperio del orden moral subordinándole el orden natural, lo que equivale a subordinar la fuerza a la justicia, reconociendo como base fundamental de la sociedad las leyes eternas de la razón conoce y promulga, o sólo se reconoce el orden natural subordinándole el derecho, lo que equivale a anular éste, no reconociendo más ley ni más razón que la fuerza bruta, o la ley divina o el fatalismo. No hay medio" (Citado por Valderrama, 1961:184).

Consecuente con lo anterior, el sentido de la utilidad es reencauzado, ya que para Caro esta palabra en sí misma no significa nada. Útil es lo conducente, el vehículo. "Hablar de utilidad en general -dice Caro-es como hablar de dirección" (Valderrama, 1961:187). De esta manera se pretende iniciar el reposicionamiento de una de las ideas fundantes del utilitarismo: "para el partidario del principio de la utilidad la virtud no es un bien sino a causa de los placeres que de ella se derivan y el vicio no es un mal sino a causa de las penas que conlleva" (Valderrama, 1961: 188).

A esta posición Caro le endilga dos errores:

"la del que considera la utilidad como bien es sí, bien absoluto, y la que considera como buena o mala según las circunstancias que la condicionan. En el primer caso tenemos un error evidente: una valoración absoluta de algo contingente. En el segundo caso nos encontramos ante algo complejo. Se parte de ideas formadas sobre el bien y el mal. (...) La tesis utilitarista se viene sin embargo al suelo, por que, como es bien sabido, las ideas de placer y de dolor son relativas, pudiéndose dar placeres buenos y malos como también dolores buenos y malos" (citado por Valderrama, 1961:189).

Para que la utilidad tenga la calidad de bien, la ley humana o positiva debe estar sujeta a los designios divinos; expresados por medio de ley natural, "estos principios morales, reconocidos más o menos claramente, son el fundamento y el objeto de todas las legislaciones del mundo". (...) La ley natural, interpretada en buen o mal sentido, siempre será la base fundamental de todo código divino" (Valderrama, 1961:189).

Para continuar este punto falta hacer una mención al orden moral frente al orden jurídico. En este punto Caro hace una crítica a Kant y Fichte. Reconoce en estos dos autores como partidarios de la idea según la cual la moral es fuente original del derecho, "pero al independizar a éste para ponerlo al servicio de la libertad, aquella fuente se aleja, se olvida y hace 
ilusoria" (Valderrama, 1961:199). Esta apreciación se dirige en contra de la división que hace Kant entre actos de la conciencia, regidos por las leyes de la moral, y actos externos, regidos por las leyes positivas humanas. Según el pensamiento de nuestro autor, este tipo de alejamiento del derecho y los predicamentos divinos hace que los discípulos de este maestro lleguen a "ofrecer una doctrina política inmoral: el liberalismo moderno con su lema Laissez faire" (Valderrama, 1961:198).

Pero no sólo se queda en la crítica sino que determina cual es la relación entre moral y derecho; "moral y política son pues realidades profundamente relacionadas. La política enseña los medios adecuados al gobierno de los pueblos; la moral obliga a los gobernantes al bien común, al servicio público" (Valderrama, 1961:207). Esto es evidente en su advertencia a los gobiernos y hombres públicos:

"Los que se destinan al gobierno del Estado, tengan muy presente las dos máximas de Platón: la primera, que han de mirar de tal manera por el bien de los ciudadanos, que refieran a este fin todas sus acciones, olvidándose de sus propias conveniencias; la segunda, que su cuidado y vigilancia se extienda a todo el cuerpo de la república, no sea que por mostrarse celoso con una parte desamparen las demás. Los negocios e intereses del Estado se pueden comprar con la tutela, la cual se ha de administrar con atención al provecho de los que se entregan a ella y no de aquéllos a quienes se ha encomendado" (Valderrama, 1961:207).

Miguel Antonio Caro ve roles que determinan la división social de la labor educativa entre la madre y el padre.

"El hombre, considerado individualmente, se perfecciona mediante una doble educación, la de la naturaleza y la de Dios. La naturaleza, tocando los resortes de nuestra sensibilidad, nos educa en lo material, por medio de atractivos y repugnancias sensuales, o sean sensaciones agradables y penosas; esta educación es común con el bruto. Dios nos educa ilustrando nuestra razón por medio de atractivos y repugnancias intelectuales, esto es, por medio de intuiciones de lo bueno y de lo malo... Por medio de las sensaciones se educa el animal; por medio de sensaciones y conocimientos, el hombre" (Caro, 1962). Esta división también indica una diferenciación de roles.

"La familia es el tipo más natural y feliz de sociedad humana, y en ella vemos muy bien realizado, en su escala, el ensanche que debe dar la autoridad o poder público a la educación individual. Por punto general, para el niño, tipo del 
hombre educando, la madre representa a la naturaleza, el padre a Dios. La educación de la naturaleza es imperfecta; sus lecciones generales son correctas, pero descuida a menudo las especiales, olvida los pormenores... Pues bien, una madre atiende a estos pormenores olvidados por la naturaleza; constitúyanse en su agente y eficaz auxiliar, distribuyen aquí y allá, motivos de pena o de gusto, para que el niño busque lo bueno y evite lo malo. ¿Qué hace la madre que endulza un medicamento amargo, sino sustituir el signo atractivo al repulsivo en un objeto bueno, en la circunstancia en que se emplea; o en otros términos, hacer individualmente lo que la naturaleza hace en sentido general? ... El padre, por su parte, cuida más especialmente de la educación racional del niño, y representa, no y a a la naturaleza, sino a Dios ... Para nosotros, la sociedad es una gran familia, y su misión la misma que, en su escala cumplen los padres de familia: educar por medio de la sensación y de la idea; la autoridad pública debe perfeccionar al hombre como la autoridad doméstica perfecciona al niño ... Según esto, la misión del poder público, en cuanto perfecciona la educación de la naturaleza, consiste más bien en enunciar mediante dolores prohibitivos el mal, que en infamarlo, una vez ejecutado, mediante dolores simplemente instructivos" (Caro, 1962.)

Así las cosas, cuando alguien comete un delito, lo que hace la autoridad pública es a través de un mal hacer un bien.

"Pongamos un ejemplo. En una agresión injusta hay dos males: el mal moral, el pecado, que consiste en la violación del orden moral y que se inicia por el agresor, y un mal material, la violación del orden fisico, que recae en el agredido. La naturaleza mediante una sensación desagradable hace sentir al último el mal fisico que experimenta; pero no siempre ni oportunamente, si alguna vez, hace sentir al primero el mal moral que ejecuta. Imperfecta es como se ve, la instrucción de la naturaleza en el caso propuesto; ella no alcanza a detener, mediante un dolor, el brazo que hiere; apenas puede avisar del mal al pecho amenazado o herido. De aqui la necesidad, el derecho que tiene la sociedad a hacer sentir al agresor también el mal que ejerce, como la naturaleza anuncia el mal fisico al agredido" (Caro, 1962).

La iglesia es la que cumple la labor del padre. Ya dijimos que la verdad es anterior a la razón y que se nos presenta en forma de ley natural; "la verdad solo se puede enseñar en nombre de Dios" y "sólo la iglesia católica enseña la verdad moral, apoyada, no en la razón humana, débil y contradictoria, no en el mayor número ni en la mayor fuerza, o sea en la razón pagana, sino en la palabra de Jesucristo, que dijo: yo soy la verdad. Id, enseñad a todas la gentes" (Caro, 1962:1341). Esta es una de las razones por las cuales el 
régimen regenerador ${ }^{29}$ delegó a la iglesia la educación: y generó una situación de conflicto entre la patria potestad y la autoridad del Estado. Caro dice que en primer lugar se invade el campo del derecho civil, "en cuanto se hace referencia a los derechos anexos a la patria potestad, que por esta resolución se declaran absolutos, y al menor de edad, sobre la cual nada se determina en lo tocante al ejercicio de la libertad religiosa" (Caro, 1986a: 17) La concepción romana de este derecho (patria potestad) debe ser modificada por la civilización cristiana. El padre no tiene derecho a maltratarle ni a mutilarle, "el padre no tiene derecho a privar al hijo del alimento necesario para su desenvolvimiento físico; tampoco podrá por lo mismo quitarle lícitamente el alimento moral" (Caro, 1986a: 17). El padre puede decidir qué instrucción o credo profesar, más nunca llegará a cercenarla.

Era posible en el Estado anterior (Estados Unidos de Colombia) cometer la imprudencia, con la educación laica, de someter al niño "al molde de una especie inferior en la escala de los seres animados" (Caro, 1986a: 17). En el nuevo sistema el padre puede no darle educación a su hijo (no es obligatoria), pero si decide que se instruya, no debe dejársele esta garantía, a todas luces abusiva según el autor. No se puede permitir que el padre se inmiscuya en la escuela para que cometa un abuso en contra de una débil criatura.

De otro lado, tampoco el Estado puede determinar los contenidos de la misma. Únicamente tiene que agenciar las garantías, para que lo pueda hacer la iglesia; "el padre instruye al niño en los rudimentos de la doctrina, lo educa cristianamente, sin que por eso haga para con él los oficios que solo corresponden al sacerdote. Lo mismo del Estado: la legislación civil debe ser cristiana en su espíritu, sin que por eso asuma el Estado los poderes que corresponden a la Iglesia" (Caro, 1962:169).

"el legislador de 1886 se preocupó mucho por asegurar la verdadera libertad e independencia de la iglesia, por abrir ancho campo a su acción civilizadora, condenando igualmente los odiosos actos de persecución decretados por enemigo declarado y las peligrosas intromisiones jurídicas del tradicional patronato. El resultado está a la vista: la autoridad eclesiástica es acatada y respetada en toda la república, su acción es libre, sin vetos ni restricciones humillantes, en todo lo que es de la competencia del poder espiritual conforme a la doctrina católica... no hay una voz que se levante a contradecir sus enseñanzas, y la

29 La razón del mayor número y de la fuerza Caro la atribuye a los radicales. Ellos dicen que la fuerza de la verdad nace de la mayoría, o del derecho de gentes (forma en que, en los Estados Federales ejerció Mosquera la dictadura), que a ellos hay que atenerse. 
instrucción pública oficial, germen y garantía de lo que ha de venir luego, está sometida en absoluto a la inspección de la iglesia" (Caro, 1986b:57).

En la anteriores apreciaciones encontramos la idea de lo uno y lo múltiplo en relación con la división de roles ${ }^{30}$, justamente en la dinámica operativa de una tecnología de sujeción a cargo de la institución familiar y escolar, asegurando la adquisición de competencias específicas para el manejo del arpegio de posibilidades cognoscitivas de la época, logrando a la vez, la galvanización de un sistema de creencias cuyo marcado acento religiosa da solidez y coherencia a una cierta imagen del mundo, plagada de alusiones al Verbo, la sagrada familia, el ejemplo de santidad de Jesucristo y todos los Santos, imposibilitando de todos modos la posibilidad de percibir el entorno de alguna manera distinta.

Esta es una complementariedad que tiene como centro atracción el elemento unificador de la nación, de la personalidad colombiana, la religión. Este elemento unificador, en el pensamiento historiográfico del autor de la constitución de 1886, quedó marcado desde la edad media: "La monarquía cristiana y la familia cristiana son hijas de la educación eclesiástica de la edad media. La legislación siempre ha quedado impregnada de la idea cristiana, lo mismo que la educación doméstica" (Valderrama, 1961:203).

Hasta aquí hemos delineado la construcción de la personalidad y del Estado., pero cabe una pregunta: ¿Cuál es el fundamento para educar a los brutos? ¿Cuáles son las herramientas? Ya dijimos antes que es a través de la labor maternal de asistir a la educación de la naturaleza, pero nada hemos dicho de su fundamento y forma de operar.

\subsection{CARO Y LA EPISTEMOLOGÍA}

Se propone en este punto una revisión de los escritos de Miguel Antonio Caro a propósito de las "ideas innatas". Consideramos que en vocabulario filosófico del regenerador bogotano, este es el concepto que más se aproxima a lo que, en esta monografía, y desde el punto de vista de la Historia Discursiva, hemos denominado "Discurso". Es decir aquel entramado simbólico que confiere sentido a la experiencia de lo real, objeto privilegiado de la pesquisa del historiador. La gran diferencia está en carácter eterno e inamovible que tienen las ideas innatas para Caro, siguiendo muy de cerca

30 Ver en Caro y la epistemología la necesidad de la unidad en la multiplicidad. 
las argumentaciones onto-teológicas del dogma católico, y la naturaleza histórica, construida y contingente, que tienen estos esquemas cognitivos en el marco teórico que orienta este trabajo.

Comencemos entonces a explicitar las diferencias entre el orden racional trascendente/superior y el inmanente/inferior. Ambos para Caro se fundamentan en la fe, pues participan del principio de autoridad. La autoridad de la ciencia (orden inferior sin la intuición, que es manifestación de lo divino, como veremos más adelante) se cimienta en la fe que se tenga al procedimiento o al científico que produjo. La autoridad del orden racional superior se basa en la autoridad de la persona que lo produjo (autoridad relacionada con la religión), y se refleja en un acto de humildad en el "que el hombre no conoce de las cosas que cree [sino] las razones intrínsecas [diferente de las extrínsecas, propias de la inducción o la deducción], que están en Dios"31. Al primero lo denomina criterio de razonamiento, al segundo de autoridad propiamente dicho. "La dificultad está en saber distinguir; pero esta dificultad existe en ambos criterios y si fuese motivo para deshacer el de autoridad lo sería también para desechar el de racionamiento" (Caro, 1962) ${ }^{32}$.

Hay que entender, cuando nos dice Caro “autoridad es razón” lo siguiente: "entendemos por razón un motivo justo, legítimo y poderoso que nos mueve a aceptar un hecho de que no tenemos pruebas experimentales, un hecho que no hemos visto y que acaso no alcanzamos a comprender"33; "es lo cierto que creemos en cosas que no hemos visto, no porque no las hayamos visto sino a pesar de haberlas visto, por razón de autoridad" (Valderrama, 1961: 353).

Este principio de autoridad se sustenta en Caro como fundamento eterno, divino de lo propiamente histórico, y lo hayamos en toda sociedad. Todo lo cual se erige en principio de homogenización de lo diverso, piedra de toque del concepto de Persona que venimos analizando.

La razón de autoridad más valedera para Caro se encuentra en el orden superior, que es el nivel de la divinidad; este se basa en el precepto "Dios no puede engañarse ni engañarnos". Frase perfectamente oponible a la epistemología filosófica de raigambre Nietzscheana, para la cual la idea

31 Caro, M. A. “En dónde está la autoridad”. En: La unión católica. 23 de julio de 1871. los paréntesis fuera del texto original.

32 Caro, M. A. “Autoridad es razón”. En: La unión católica. 23 de julio de 1871.

33 Ibídem. 
de Dios ha estallado en una infinidad de simulacros, verdades regulatorias, ficciones lógicas; situación comparable a lo que en el pensamiento filosófico post-estructuralista es tomado como una inversión del platonismo ${ }^{34}$.

La sensibilidad, entonces, pone en frente del entendimiento los datos, pero estos por si solos no llevan sabiduría ${ }^{35}$. Las ideas innatas o trascendentales se encuentran más en la "intuición" de los hombres que en las "complicadas" formas en que se expresan los razonamientos del orden inferior. Este razonamiento de Caro, sostiene Valderrama, se encuentra también en San Agustín:

"La raiz de este criterio la encontramos en la afirmación que hace San Agustín de que la imagen divina marca la parte más noble del alma humana, permitiéndole el conocimiento de Dios, no obstante la imagen de aquella naturaleza vence en bondad, se ha de buscar y encontrar en la parte más noble de nuestro ser" (Valderrama, 1961: 313).

A este criterio trascendental es al que somete Caro el conocimiento:

"La razón o criterio sobrenatural, por esto, al permitirle al hombre sentir en sí el poder de la visión intuitiva y comprensiva, le facilita la comprensión de la naturaleza de Dios, a cuya visión omnipresente ve sometido asi el movimiento del planeta como el de la hoja de un árbol. Es decir que la razón sobrenatural tiene nociones más comprensivas que la natural, nociones que, al explicarse a la expresión de las ideas religiosas, hacen difícil su explicación con los medios propios con se enuncian las verdades naturales" (Valderrama, 1961: 315).

Esta es una razón por la que las ideas innatas escapan a la lógica de la codificación del lenguaje científico. "La razón superior posee ideas comprensivas, intuitivas, que no se compilan en el diccionario de la razón inferior, sino que resuenan puras y vibrantes en la lira del sentimiento" (Valderrama, 1961: 316).

34 Además de los casos paradigmáticos de Nietzsche, Heidegger, Foucault, Derrida o Deleuze, hallamos explícita mención a este tema en el sujeto y la máscara, donde muy a propósito del concepto dramatúrgico de Persona, Gianni Vattimo encuentra al simulacro en el lugar del zócalo ontológico del logocentrismo occidental, a partir de lo cual se propone un pensamiento del Devenir, del fingimiento como esencia, del transcurrir dionisíaco y no arquetípico ni absoluto de los caracteres de la personalidad.

35 "Toda interpretación supone leyes de interpretación, juez que interpreta y materia que ha de interpretarse. La materia son los datos de la sensibilidad, juez el entendimiento. Estas leyes, estos principios mismos son los que unos llaman formas de la razón y otras ideas trascendentales. Son la luz que tiene todo hombre que viene a este mundo; luz sobrenatural, participación de la divina luz" (Valderrama, 1961: 309). 
La relación entre lenguaje y la ideas innatas lo encontramos en la concepción de proposición: "Si la proposición sólo representara con espontaneidad los pensamientos individuales sería infinitamente variada su estructura, como varios son estos pensamientos" (Valderrama, 1961: 329), "lejos de eso la proposición es siempre una y donde quiera una; lo cual demuestra que ella no expresa pensamientos individuales, sino con la precisa condición de presentarlos bajo la forma de un pensamiento general de que ella es inmediato traslado" (Valderrama, 1961: 328). Lo anterior manifiesta una estrecha relación con el concepto de Persona, ya que es el verbo (el divino que enlaza las ideas innatas y es el denominador común) quien da el carácter de sujeto a las cosas. "El nombre aisladamente denota una cosa; como sujeto del verbo, denota una persona. La proposición, pues, por el sujeto, esto es, por el nombre, en cuanto a él se refiere el verbo, presupone la noción de substancia” (Valderrama, 1961: 329). He aquí el carácter individualizante del nombre, haciendo unívoca la referencia a algo o a alguien en concurso con la forma verbal. Generalizando para nombrar, situar, circunscribir con exactitud la proliferación desmedida del significado. Esto es precisamente lo que pone de manifiesto la condición de abstracción que se establece en el verbo, ya que allí se pone en consideración la relación de causa y efecto: "Pero como para abstraer el atributo se presupone la substancia, es decir, un ser independiente, una personalidad, de aquí la noción de causa y efecto. El atributo es al supuesto como un efecto a su causa" (Valderrama, 1961: 329), "ahora, como el entendimiento juzga naturalmente de todas las cosas en esta forma, puede decirse que es por instinto (razón sobrenatural) que se admiten la pluralidad de sustancias, de seres independientes, de los objetos con su principio propio de actividad" (Valderrama, 1961: 329).

Pero esta generalidad de sustancias y de atributos (de la personalidad) es la que le permite al hombre conocer las ideas generales según Caro; el atributo al separarse del sujeto hace posible ver géneros, de unos y de otros, y así permitirse llegar a los tipos ideales. "En virtud del verbo el atributo no sólo se separa del sujeto, sino que se considera genérico y de mayor extensión que el sujeto mismo" (Valderrama, 1961: 330). Esto también permite el establecimiento de jerarquías y distinciones.

Aquí se muestra otro de los atributos del verbo: la identificación. "El atributo que se abstrae y generaliza no subsiste en la mente, atendida la fuerza del verbo, disociado del sujeto de donde, digámoslo así, salió, sino 
que torna a unirse a él íntima y esencialmente (...) Afirmamos la identidad de la cosa que explícitamente distinguimos" (Valderrama, 1961: 331).

Esto es lo que Carlos Valderrama denomina: Unidad en la Pluralidad. La unidad en la pluralidad es un rasgo esencial de la sustancia (que aquí acompasamos con la idea de personalidad). "La unidad sin pluralidad es absolutamente estéril; todas nuestras percepciones son compuestas; necesitamos multiplicar la unidad para concebirla y expresarla, es decir, para fecundarla. Por su parte la pluralidad sin unidad es contradictoria" (Valderrama, 1961: 332). Para Carlos Valderrama, exponiendo el pensamiento de Caro, "todo juicio es la afirmación de la unidad en la pluralidad”. (Valderrama, 1961: 329)

Estas, las ideas de autoridad de la razón y de ideas innatas, entre otras razones, son las que llevan a Caro a establecer su crítica contra el método cartesiano en INFORME SOBRE LOS "ELEMENTOS DE LA IDEOLOGÍA" De Tracy:

"Al método cartesiano Caro hace dos objeciones: en primer lugar, no es posible practicarlo con absoluta pureza, por que aun en la suposición del más independiente de los pensadores, siempre rinde tributo, aunque inconsciente, a su propia autoridad; en segundo lugar, concediendo por hipótesis que se pudiera poner en práctica con total pureza, resultaría incompleto e insuficiente. El método cartesiano es impracticable en toda su integridad, porque si lo fuera, sería necesario que en nuestras investigaciones pudiéramos poner un edificio científico con absoluta prescindencia de aquellos principios fundamentales que Dios ha puesto en nuestro entendimiento, de espaldas a la tradición que con celo los guarda y haciendo abstracción de las circunstancias que nos condicionan necesariamente" (Valderrama, 1961: 248).

Este desarraigo que presenta el principio pienso, luego existo no salta con facilidad el obstáculo del idioma. Podemos deducir, en consecuencia, que a pesar de plantearse una cierta complementariedad entre lo Uno y lo múltiplo, es en el primero que haya nuestro autor el sustento de su modelo epistemológico; de tal suerte que el polo marcado con énfasis es el de la reducción de la complejidad, un disciplinamiento de las diferencias, las multiplicidades y polivocidades a la autoridad de las ideas innatas, en un intento por cimentar en valores inconmovibles las mudables manifestaciones del habla de los sujetos, coagulando en un molde divino el magma amorfo del devenir expresivo de las personas, circunscribiéndolo a un Genio lingüístico único, el de la lengua castellana, pura, gramaticalmente completa, excluyente de toda ambigüedad. Para una posición como la de Caro, las formas de entender el 
mundo no solo no cambian, como es obvio; sino que se hallan predeterminadas en un nivel de abstracción metafísico, inalcanzable: la inaccesible e infinitamente de Dios: nunca podremos pensar de manera distinta.

\subsection{LA PERSONA IMPUTABLE}

Al bruto, al des(con)centrado, a aquel que no piensa, no podría imputársele nada a menos que en el hombre se reconozca la existencia del libre albedrío. En principio el hombre es movido por la sensibilidad, llevado por inclinaciones naturales. Al desarrollarse la inteligencia se despliega la voluntad o libre albedrío: "libre para determinarse, tiene el hombre, alrededor de la voluntad dos clases de principios motores: los móviles (instintos) y los motivos (intelectuales)" (Caro, 1962: 65); cuando ellos surgen puede suceder: o que los instintos aparezcan y entonces gane el más fuerte (situación que ocurre antes o durante la deliberación) o que, por la deliberación, la voluntad determine la acción (la pasión no existe en la región intelectual).

"Cuando un hombre se ve asediado v.g. por la ira de un lado, y por otro aconsejado por la razón, sucede que, o procediendo indeliberadamente es arrastrado de aquélla, o bien la sofoca o la reprime una vez conocida, es decir, investida siquiera sea momentáneamente, de forma racional. Previa deliberación y fallo, puede todavía el hombre decidir en uno u otro sentido: acto supremo de libertad" (Caro, 1962: 65).

Con esta paráfrasis del Estudio sobre el Utilitarismo de Miguel Antonio Caro pretendemos abordar la problemática del sujeto jurídico como sujeto responsable: los modos de su construcción discursiva, el establecimiento de un horizonte de libertad como criterio supremo de identificación de la consciencia, el yo, la persona como instancia reflexiva, autorreferente, sometible a castigo o premio, tal como pueden rastrearse estas propiedades en las actuaciones verbales de Miguel Antonio Caro, configurador de tal noción de Persona en el naciente orden jurídico de la República centralizada. Conectando, de este modo, las anteriores reflexiones sobre la elaboración de un referente de Persona, acorde a la tradición hispánica, el orden católico, y la instauración hegemónica del proyecto Regenerador como un régimen de Discurso.

Manejaremos el ejemplo de la indulgencia, para evidenciar el modo caritativo de administrar la pena que propugnaba Caro, desvelando así el 
modo en que se comprendió y sancionó legalmente el límite de la libertad del sujeto jurídico, las consideraciones filosóficas acerca del grado de culpabilidad de quien ha transgredido el orden social de la época.

Para el Derecho Penal, "el fundamento de la imputabilidad, es, pues, ... el libre albedrío, considera que todo hombre que está en uso de sus facultades puede hacer que su voluntad resista a los impulsos criminales, o mejor, que él es dueño de obrar o no obrar y por lo mismo responsable de sus acciones" (Medina, 1921). El bruto, no puede ser condenado por tal razón (Caro, 1986b: 151); en algunos casos es merecedor de piedad. Según Caro:

"las penas son en parte vindicta necesaria, y en parte medicina saludable, en este concepto la pena participa de la naturaleza de la indulgencia, en cuanto de esta, aplicada con oportunidad y mesura, podemos esperar también eficacia medicinal, como muestra de magnanimidad y conmovedor reflejo de la misericordia divina, que procura la conversión de los que delinquen con reestímulos de gracia" (Caro, 1986a: 40).

Caro no aplica el rigor a los que no amenazan con descentrar la patria; "Si los que se mezclaron en la asonada del 16 de enero hubiesen sido sometidos a sus jueces naturales, como por espíritu de oposición al gobierno, se ha dicho que debió hacerse, cuántas personas no hubieran sido condenadas a algunos años de prisión y a otras penas rigurosas, salvo prevaricación de los jueces, que no ha de suponerse ... Procedió así el gobierno por que consideró el tumulto como un extravio del momento, y no como resultado de una labor fría y sistemática que trata de minar por sus cimientos el orden establecido" (Caro, 1991: 43).

Este fue el argumento que esgrimió para proceder a la rebaja de penas con motivo de la conmemoración de un aniversario del descubrimiento de América. Incluso los radicales se benefician de esa bondad:

"Os invito a la reconciliación, sin peligro ni detrimento de la justicia, porque la justicia no está encomendada a las pasiones de los hombres, que la desvirtúan, sino a la leyes y a los tribunales de la república"... "un gobierno justo, que se ha visto amenazado de continuo por conspiraciones temerarias, quiere dar el ejemplo con una muestra de indulgencia y hoy se decreta la libertad de los pocos individuos que en el territorio de la república están detenidos o confinados por motivos políticos. Esta gracia se hará extensiva a los que, hallándose por la misma causa desterrados, quieran volver al seno de la patria como ciudadanos pacificos y no como agitadores ... Espero que al olvido no se responda con rencor". (Caro, 1991: 88-89)". 
El condenable es el hombre que persiste en ser egoísta y el que quiere des-centrar (entiéndase federar,) a Colombia. Los que intentan "racional y sistemáticamente" acabar con el nombre propio de Colombia. Los que insisten en traicionar la tradición de los libertadores. Los que intentan matar al soberano para que los referentes del poder se disocien (soberanía popular, soberanía provincial y soberanía individual). Los que intentan hacer de los individuos sujetos de sus pasiones. Los que intentan transformar lo Uno en peligrosa multiplicidad inmanejable. Aquel que "obra racionalmente; pero su razón no es sino administradora de sus pasiones, se sirve a si mismo por gusto, no por deber. No tiene la verdadera idea del deber" (Caro, 1962: 70).

Tras la caracterización de este sujeto egoísta (el anarquista y el revolucionario) se esconden todas las reformas que hasta aquí veníamos anunciando. Para sujetar a población al imperio de la razón, de la ley, se sostiene:

"esta es la ocasión de iniciar en algunos ramos de nuestra legislación y en el de instrucción pública modificaciones cristianas y profundas. Respeto a autoridad; severas penas contra los crimenes atroces, inexorable castigo de los delincuentes; ampliación de los periodos administrativos; proscripción del fanatismo irreligioso, el más dañino de todos los fanatismos; prácticas y enseñanzas religiosas en los colegios oficiales, como medio indispensable de disciplina y moralización; alianza de todos los hombres amantes de la familia y de la patria para impedir, por medios legales, que vuelvan al poder los anarquistas, -tales son los puntos de vista a que deben convenir ante todo, su pensamiento y su acción el partido independiente, si quiere afianzar su popularidad y merecer el bien de la república" (Caro, 1986b: 60-61).

Esta forma de concatenar el discurso es la que explica las aparentes contradicciones. Explica por qué pide a viva voz la pena de muerte y al mismo tiempo la facultad del indulto. Así se explica porqué, aunque en todo momento diga que nuestra patria es uniforme, persista en que al presidente se le den amplias facultades extraordinarias para mantener el orden. Esta forma de encadenar el discurso nos permite entender la predicación de independencia de la Iglesia y el Estado, por un lado, y por otro, la intromisión de la misma en el proyecto regenerador.

He aquí el nuevo orden del discurso que se estableció en la construcción de la personalidad y el sujeto imputable. Pero vayamos a un ejemplo específico. 


\subsection{El Paradigma: Miguel Antonio Caro y Andrés Bello}

Lo que interesa a este acercamiento al pensamiento de Caro es dar una ojeada sucinta en los escritos sobre Andrés Bello, a la relación entre la personalidad que sobre éste autor dibuja Caro y su propuesta "sociopolítica". Buscamos enlazar lo precedentemente dicho no solo en la construcción enunciativa del sujeto Caro, sino a partir de la idealización del sujeto Andrés Bello, que para el bogotano pasará a ser modelo sobre el que verterá la retórica de su concepto de Persona. La lectura que se propone de "los escritos sobre Andrés Bello" no intentan calificar de buena o mala la apreciación que sobre él tiene Caro; la búsqueda que en ellos se hace presenta otra dirección: analizar los modos de la reificación, la idealización historiográfica y moral de don Andrés Bello.

Ve Caro en Bello un intachable hombre, que con lucidez supo navegar por los mares tranquilos de la contemplación y la reflexión, más que por las turbulentas mareas de las armas y de la guerra:

"La [vida]de Bello, por una rara y feliz excepción, destinada a traspasar los términos ordinarios de la existencia humana, hubo de dar un rodeo fuera del teatro sangriento y llameante de la guerra. Diez y ocho años permaneció en Londres sirviendo ya a su patria, ya a la república de Chile, en la carrera diplomática, y ora en algún desahogado acomodo, ya en la extrema pobreza, continuando siempre sus estudios literarios y cientificos. De allí contempló de lejos, bien que con un interés patriótico, las peripecias de la terrible lucha; cantó a sus héroes y mártires; pero pudo por su situación material, mantenerse ajeno de los odios vengativos que convierten a los hombres en fieras" (Caro, 1981: 118-119).

Estas cualidades y su prodigioso destino le permiten identificar en Bello, hombre eminente de letras, las características de aquellos que lamentablemente perdieron las nacientes patrias por la guerra de independencia.

"Sin la revolución de la independencia, jcuántos hombres notables en letras no hubieran llegado a la madurez de la edad y el término de una carrera gloriosa! Pero vana hipótesis: precisamente el estado a que llegó la educación intelectual y cultura cientifica de los americanos coincidiese, con la hora de la emancipación, y la emancipación no pudo comprarse sino a gran precio, con sacrificio de nobles talentos y de vidas preciosas" (Caro, 1981: 118)

Hay que señalar, además, que una de las citas que trae en "Ojeada a las Opiniones Políticas y Religiosas de Don Andrés Bello” refuerza esta 
sensación; la tarea que a Andrés Bello le asigna nuestro autor, es la misma que éste se plantea como hacedor de la tarea inconclusa que legaron los padres de la patria: la de brindar estabilidad e institucionalidad a las nacientes patrias (tarea siempre traicionada por los liberales descentrados):

"Testigo más abonado, don, Federico Errázuiz, que en época posterior fue presidente de la república chilena, enumera así en 1865 los merecimientos de Bello:

Los más preciosos adelantamientos que hemos obtenido en la vida del progreso literario y científico, los adelantos de la inteligencia, se hallan inseparablemente vinculados en el nombre de Andrés Bello. Padre y fundador de nuestra literatura nacional, ella le debe el estado floreciente en que se encuentra. La ciencia del derecho le debe obras inmortales, textos de enseñanza inestimables, discípulos distinguidos y profundas y sabias leyes, y un monumento imperecedero de sabiduría y de genio en la gran obra de nuestro código civil. La política es deudora de la dirección, durante larga serie de años, de nuestras relaciones exteriores que siempre llevó con acierto, con brillo y con dignidad (...)” (Caro, 1981: 120).

Verdadero modelo, Bello es representado según códigos de compostura moral que le asignan el papel de protagonista intachable.

Dentro de las ideas que contempló en su genio; Bello, según Caro, rechazó la postura que niega el cultivo de la tradición cultural española. "Por el hecho de haber sacudido el yugo del gobierno español, ¿debiéramos renegar de nuestra raza, apostatar de nuestras creencias, desnudarnos de cuanto por la tradición o la sangre hemos recibido en herencia, no por razón de que sea bueno o malo, sino sólo porque es español?" (Caro, 1981: 124). Esta pegunta la responde Caro con la siguiente cita de Bello:

"Siguiendo el impulso de ese legítimo y honroso sentimiento -continua Bello en el lugar citado-, lejos de degenerar de nuestros mayores creemos obrar en el espiritu de sus antiguas instituciones, e imitarlas mejor, que los que desconociéndolas, las tienen por invenciones de extranjeros, etc." (Caro, 1981: 118-119). Vemos aquí el claro ejemplo del carácter irrenunciable del legado cultural español, que a la manera de un Destino ineluctable, sanciona el futuro de las nacientes Repúblicas americanas.

Reproduce Miguel Antonio Caro en los trazos de la persona de Bello su propia apreciación de la reivindicación de la cultura española y de la raza latina. El llamado a la tradición hispánica los reproduce a través de los labios de Bello; se despersonaliza para utilizar el rostro del monumento que elabora del autor del código civil. 
A partir de este criterio eleva una taxonomía para encasillar a los hombres que guiaron la independencia. "La opinión patriótica, madre de la independencia, puede dividirse, desde sus primeras manifestaciones, en dos escuelas antagónicas, en dos tendencias opuestas" (Caro, 1981: 122). Esta división coincide plenamente con la división, que nosotros hemos señalado, entre concentrados y descentrados:

"Querían los hombres sensatos y prudentes conquistar la independencia, como bien supremo, como satisfacción de urgente e imperiosa necesidad, pero a costa de los demás bienes. Creían que, si bien las costumbres pedian una dirección menos entrabada y más libres, y la legislación debia purgarse de los vicios que la afeaban, esas costumbres españolas y esas leyes romano-ibéricas que eran ya nuestras, debian servir de base y cimiento a la construcción de los nuevos Estados (...) Dueños de la casa que otros dominaron, no había por odio a sus predecesores, de despedazar los muebles y tirar los adornos, ni menos destechar el edificio, derribar los muros y destruir todo por sus cimientos. Progreso en la tradición, libertad en el orden, era su divisa" (Caro, 1981: 122).

\section{Además,}

"Los otros, guiados de odio, llevan por sistema negaciones, y eran en la acción revolucionarios. Creían debía hacerse guerra a muerte al enemigo, y extremarlo; pero en su ciego fanatismo no echaban de ver que el terreno cultivado que ganaban al enemigo, iba a ser de ellos, y que por consiguiente el sistema destructivo que aplicaban a sus conquistas y adquisiciones, redundaba en su daño, y en daño, sobre todo de sus hijos y sucesores. No pensaban en la familia, ni en el porvenir; en pos de sí, el diluvio. (...) Excluyendo los elementos tradicionales e indigenas, los unos querían traer de Francia, de la Unión Angloamericana los otros, las piedras angulares, las maderas, los materiales todos que habian de servir para levantar de nueva planta el edificio" (Caro, 1981: 123).

En el aparte anterior podemos observar, además, la sutil mención que de nuevo se hace a la raza latina, conjugándola con su criterio de desconocimiento que hacen los descentrados, los liberales ${ }^{36}$, de la tradición. A la vez que vemos en su funcionamiento más evidente el mecanismo de las distinciones entre lo bueno y lo malo a partir de intereses políticos dados por descontado.

36 Frente a la división que presentamos en los dos párrafos anteriores Caro dice: "Tal fue el origen del partido conservador y tradicional por una parte, y del liberal y revolucionario por otra, en la América española". (Caro, 1981: 123). 
Dicho en otro lugar de este trabajo se encuentra la afirmación según la cual, en criterio de Caro, nuestra raza es una combinación entre el pacífico indígena y el gallardo español; esta aseveración se reafirma en la cita anterior en donde se reprocha el desconocimiento de "los elementos tradicionales e indígenas", pero incluidos de tal manera que jamás constituyan un riesgo para los presupuestos socio-políticos y de dominación económica del proyecto Regenerador.

En otra parte se sostiene:

"Nuestras Tradiciones históricas y costumbres sociales, aquéllas con sus enseñanzas y éstas con el fecundo centro de irradiación que tienen en el hogar doméstico; el catolicismo con sus doctrinas redentoras y altos ejemplos que nos da así nobles sentimientos como de severa disciplina (...); con sus irreemplazables maestros del pueblo y de la juventud; -el derecho romano, y la legislación española y de Indias, como antecedentes de nuestra actual organización, con las modificaciones exigidas por las que ha experimentado, sin dejar de ser latina, nuestra raza americana;- la lengua castellana, la más hermosa y robusta de las romanas, con las ventajas que ofrece como depósito de ideas y como medio de comunicarlas: tales son los elementos principales de nuestra peculiar civilización (...) Y todos estos elementos, fundamentales y constitutivos de la sociedad hispanoamericana, han sido objeto de secretas maquinaciones primero, y después, de rudas y desembozadas embestidas; $y$ de todos ellos en uno u otro terreno, fue defensor Bello" (Caro, 1981: 129).

También es de resaltar la mención que hace Caro en el texto aquí analizado, de la visión que tiene la independencia en Andrés Bello; esta se corresponde con visión que defiende nuestro autor y que se basa en el "espíritu gallardo español que rechaza la opresión" que inspiró la emancipación. Estas son las palabras que rescata:

"Jamás un pueblo profundamente envilecido -replica Bello- fue capaz de ejecutar los grandes hechos que ilustraron las campañas de los patriotas. El que observe con ojos filosóficos la historia de nuestra lucha con la metrópoli, reconocerá sin dificultad que lo que nos ha hecho prevalecer en ella, es cabalmente el elemento ibérico. Los capitanes y las legiones veteranas de la Iberia transatlántica fueron vencidos por los caudillos y los ejércitos improvisados de la otra Iberia joven, que abjurando el hombre conservaban el aliento indomable de la antigua. La constancia española se ha estrellado contra sí misma" (Caro, 1981: 124-25).

El que Bello hubiese estado cercano a los modelos Anglosajones (recordemos que Andrés Bello fue plenipotenciario de la Junta Gobernativa 
y parte del cuerpo diplomático chileno ante la corona Británica) y que no se hubiese "dejado tentar por la fiebre de la innovación", en un hecho explotado por Caro. El llamado a la autenticidad del pensamiento hispanoamericano y la continuación de las tradiciones es un elemento reiterado en el texto aquí varias veces enunciado.

Dice Caro: "En 21 de marzo de 1827, época en que el partido boliviano sentía y proclamaba la necesidad de fundar un gobierno respetable, Bello escribía al libertador:

"Siga vuestra excelencia con su acostumbrado acierto la obra de establecer el orden sobre cimientos que inspirando confianza harán reflorecer nuestros campos talados, nuestro comercio y rentas. Si no todos fueron capaces de apreciar las altas miras de vuestra excelencia (...), y se figuren que en materias constitucionales está cerrada la puerta a otras y grandes concepciones, la magnanimidad de vuestra excelencia perdonará este error, y el acierto de sus medidas desvanecerá" (Caro, 1981: 125).

La pregunta que la cita plantea es: ¿Cuáles son las doctrinas a que se cierran las puertas? ¿Cuáles son las teorías falsarias a las que se le permite la entrada? La respuesta la podemos encontrar en párrafo siguiente a la cita que acabamos de anunciar:

"La imitación de los Estados Unidos del Norte, aunque ofreciera de suyo menos peligros que el contagio de la fiebre francesa, tampoco debia ser servil ¿No ha sido vergonzosa en algunas de estas repúblicas, la copia textual del nombre de la nación, como si los nombres de personas y entidades fuesen cosa de quitar y poner a voluntad, o como si se tratase de cambiarle el rótulo a una fonda desacreditada? "(Caro, 1981: 125-126).

Se aprecia la pretensión de cristalizar en un repertorio controlable la toponimia diseminada de los países de América, ubicando en un horizonte reconocible, hispanocéntrico, la nomenclatura básica del mundo de todos los días.

Para reforzar esta tesis trae la siguiente cita de Bello:

"¿Qué situación la de nuestros países! -escribía Bello al señor Fernando Madrid en 1829, cuando llegó a Chile- iQué situación! ¡Y aún no acabamos de desengañarnos de que la imitación servil de las instituciones de los Estados Unidos, no puede acarrearnos más que estragos, desorden, anarquía falsamente denominada libertad, y despotismo militar temprano o tarde! ¿Por qué son tan raros el verdadero patriotismo y la ambición de la verdadera gloria? ¿Por qué ha vaciado la naturaleza tan pocas almas el molde de la de usted?" (Caro, 1981: 126). 
Explota con magnifica prudencia al hombre en que se inspiró los códigos civiles, que explicitan legalmente el concepto de Persona cuyo alcance y contenido se ha venido analizando. Al respecto es pertinente la historia de nuestra codificación civil:

"El conocido humanista Andrés Bello comenzó a trabajar privadamente en la elaboración de un Código Civil. (...)En 1858 el Estado soberano de Santander adoptó el código Civil de Bello, con pequeñas modificaciones. Lo mismo hicieron los Estados soberanos de Cundinamarca y Cauca en 1859, el de Panamá en 1860, los de Antioquia y Boyacá en 1864. Posteriormente, el 26 de mayo de 1873, por iniciativa del presidente Murillo Toro, se expidió el Código Civil de la Unión, que debia regir en forma unánime en todos los Estados. Se tomó como modelo el adoptado por el Estado de Santander, el cual, según se acaba de exponer, no fue otro sino el de Bello. El código civil de 1873 fue sancionado nuevamente en el año de 1887 por la Ley 57, en su art. 1-, que dice: "Regirán en la República, noventa días después de la publicación de esta Ley, con las adiciones y reformas de que ella trata, los códigos siguientes: El Civil de la Nación sancionado el 26 de mayo de 1873" (Valencia-Ortiz, 1997: 31-32).

A propósito de lo anterior, debemos mencionar la siguiente alusión que hace Caro de Bello: "Diez y ocho años residió Bello en Londres; diez y ocho años de meditación y estudio, y de contemplación desapasionada de nuestros triunfos primero, de nuestras tristes disensiones después; escuela acomodada a inspirar a cualquiera (cuánto más a un hombre como Bello) aborrecimiento por las libertades histriónicas, por la licencia desenfrenada, y amor y estimación por la libertad bien entendida y de veras asegurada (...) ¿Qué náufragos son éstos? En 1841 cantando la independencia de Chile reproducía, con más claridad, la misma imagen:

Pero del rumbo en que te engolfas, mira

Los aleves bajios

Que infamia los despojos miserables

¡Ay! De tántos (sic) navios.

Aquella que de lejos verde orilla

A la vista perece,

Es edificio aéreo de celajes

Que soplo desvanece.

Oye el bramido de alterados vientos 
$Y$ de la mar, que un blanco

Monte levanta de rizada espuma

Sobre el oculto banco.

$Y$ de las naves, las amigas naves,

Que soltaron a una

Contigo al viento las flamantes velas

Contempla la fortuna.

¿las ves, arrebatadse de las olas

Al caso extremo y triste

Apercibirse ya? ... Tú misma cerca

De zozobrar te viste" (Caro, 1981: 126-28).

Por eso no es de extrañar que Caro escribiera un artículo titulado "Bello era católico" (Caro, 1981: 261-265). Carlos Valderrama Andrade en la introducción a "Escritos sobre Don Andrés Bello" trae este realce que hace Caro a esta faceta de la personalidad de Bello. "Otro aspecto de la personalidad de Bello que Caro destaca es el de su catolicismo. Ciertamente quien dijo en versos inspirados:

La oración es infinita

Nada agota su caudal.

Tenía que ser hombre profundamente religioso. Y Bello lo fue de modo ejemplar. Así los testimonia Caro: "El primer poeta americano y primer hablista castellano del siglo, era un hombre religioso, un buen creyente" (Caro, 1981: 122).

Glosando otro pensamiento de don Andrés: "La moral que yo no separo de la religión, es la misma de la sociedad”, insistía nuestro Caro: Bello era, en efecto, creyente y observante católico" (Caro, 1981: XVIII).

Este elemento podemos conjugarlo con dos características que para Caro son transversales en su pensamiento: el elemento unificador de la sociedad e inspirador de la legislación.

Para cerrar este acápite basta señalar algunos versos traídos por Caro en la defensa de la identidad y caridad cristiana, el primero que realza a la 
religión como elemento unificador de la nacionalidad y de la tradición; y el segundo como guía para el ejercicio de la acción punitiva:

"El diez y ocho de septiembre hace votos por la prosperidad de Chile, su patria adoptiva, apostrofándola de este modo:

Cree asi tú, querida patria, crece!

Y tu cabeza altiva

Levanta ornada de laurel guerrero

Y fructüosa (sic) oliva.

Y Florezca a tu sombra la fe santa

De tus padres; y eterna

La libertad prospere, y se afiance

La dulce paz fraterna" (Caro, 1981: 261).

"El deber de caridad universal:

Ni por los que te amen sólo

El favor del cielo implores;

Por justos y pecadores,

Cristo en la cruz expiró”. (Caro, 1981: 262).

\subsection{La “Cuestión Social” para Miguel Antonio Caro}

La percepción que de la "cuestión social” tiene Caro, está atravesada por muchos de los aspectos que antes hemos enunciado; pero en ella aparece un nuevo elemento que va a jugar un papel clave en la consolidación de un tipo específico de sensibilidad ante esta problemática. Hablamos del concepto de Necesidad.

\subsubsection{El concepto de necesidad}

Para Miguel Antonio Caro el hombre y la sociedad son productos finitos y como tales son carentes, condición básica de su finitud. Como veremos más adelante, dicha finitud proviene del carácter derivado de todo el Universo respecto de la omnipotencia de Dios. En la teología política de nuestro autor, 
el espacio entre lo finito, frente a la divinidad y omnicomprensión divina es lo que abarca el concepto de necesidad. La necesidad del hombre como carencia de lo infinito para lograr su plenitud.

Pero esta carencia se caracteriza por ser dual, como la composición de los hombres. Aquí podemos encontrar un eco de la distinción platónica alma-cuerpo, con lo cual en Colombia, a finales del siglo XIX, se estaría re-editando una forma de pensamiento dicotómica, aquella heredada del modo de pensamiento de la Grecia Clásica, que en su tránsito por el cristianismo desembocaría es un sistema de correlaciones operativo e históricamente vigente, una forma de ese "Discurso" que, para Miguel Ángel Cabrera (2001), dispone la percepción de una manera específica, haciendo a los individuos percibir su entorno de cierta manera y en últimas, hacer significativos los eventos, todo a partir de un cuerpo de categorías socialmente construido; la díada cuerpo-alma funcionaria precisamente así, permitiendo entender y por lo tanto fabricar una idea de hombre y concomitantemente una imagen de la realidad consensualmente compartida. Recordemos que Caro ve en el hombre una combinación de las dos "obras de la mano de Dios que milagrosamente reunidas constituyen su criatura predilecta, cuales son el cuerpo, habitación del alma, y el alma, habitadora de nuestro cuerpo" (Caro, 1962: 707). De cuerpo y alma está compuesto el hombre, y en estas dos facetas el hombre tiene carencias.

Encontramos aquí la institucionalización discursiva de la metafísica católica, entronizada y puesta en funcionamiento por un agente enunciativo como Miguel Antonio Caro. Tal como en "El Discurso como Práctica, Lugares desde donde se escribe la historia”, Ricardo Costa y Danuta Mozejko ensayan una metodología de análisis histórico en la que lo clave es, en el sentido que venimos hablando, desnudar el mecanismo de construcción del sujeto que habla:

"esas alusiones [aquí las que hace Caro a la escatología católica] sirven para construir un modelo particular de Historia, en la que las transformaciones, provocadas por un agente social privilegiado como es el pueblo, deben ser asumidas por individuos excepcionales que den forma y orienten las pasiones descontroladas de los actores colectivos" (Costa; Mosejko, 2001: 28).

Si asumimos, entonces, que a partir de esa modelización pasional se instauran y dan por obvias clasificaciones como "cuerpo-alma", es posible historizar el surgimiento de esas categorías, de esas rejillas taxonómicas, al punto de afirmar, con Foucault (1995), que el alma es la "cárcel del 
cuerpo", o sea que el diseño de la idea de "alma" aprisiona funcionalmente las posibilidades vitales del cuerpo, encerrando entre límites manejables las posibiliades de percepción y sensación de los individuos.

Pero antes de adentrarnos a profundizar en este punto debemos anotar que la concepción, desde la óptica de la construcción del sujeto ${ }^{37}$, de "hombre" que tiene Caro, se inserta en una serie de discursos que tratan de reescribir la gramática que sobre el cuerpo-pueblo se teje; el cortesanismo señorial.

\subsubsection{Cortesanismo señorial}

Retomando los planteamientos de Zandra Pedraza Gómez, es posible afirmar que en la edad media la percepción que del cuerpo tiene la iglesia es de rechazo y negación. El cuerpo es despreciado, por entorpecer el fluir del alma. Esta situación cambia con el advenimiento y desarrollo del capitalismo, la aparición de una nueva ética, la ética burguesa ${ }^{38}$. Zandra Pedraza, citando a Bourdieu, dice: "el cuidado físico atañe a la inversión en el cuerpo; su conducta lo sitúa en el campo de la percepción social" (Pedraza, 1999: 59). Presentando el "yo", la identidad individual en el escenario de las relaciones sociales, ofreciéndolo a la vista según se acentúe o no la tensión entre condicionamientos externos (estereotipos rígidos) y creatividad (posibilidades de re-interpretar esos diseños de subjetividad), haciendo ver de cierta forma al sujeto.

La percepción social que se logra mediante el cuerpo no se sostiene en la realización de ciertos movimientos, sino en una conjunción entre movimientos, palabras y actitudes que develan la condición social de la persona. El cuerpo así concebido "vive en comunión con el alma, representa toda la identidad individual y traduce los valores sociales: a la vez refleja a la persona y su posición social" (Pedraza, 1999: 59). Revelando de esta forma un proceso de confección de la Identidad en el que confluyen "Las palabras y las cosas", regímenes de habla y regímenes de luz (Deleuze,

37 Retomamos aquí lo que en la introducción sugeríamos como eje orientador de nuestro análisis: el sujeto es un producto histórico, con lo que se vuelve relevante mostrar los mecanismos de construcción de la subjetividad presentes en un momento histórico determinado.

38 Como trasfondo de esta discusión estará siempre la seminal "Ética Protestante y el espíritu del capitalismo" de Max WEBER, que aquí referenciamos como metodología pionera en el uso de elementos culturales para explicar la modificación del comportamiento inducida por un nuevo modelo económico como el capitalismo. 
1994), cuyo dinamismo determina la concepción de la persona a partir del siglo XX en Colombia.

La cortesanía señorial ${ }^{39}$, sin embargo, se diferencia de la visión burguesa en la medida en que carga todavía con una pesada carga de moral cristiana:

"concuerda con la aplicación de principios cristianos de renuncia, y complacencia, y no contempla el placer; se concibe como un apostolado de humanidad y sacrificio, de control de las pasiones y las emociones, cuyo logro se patentiza en el principio de distinción" (Pedraza, 1999: 99).

La distinción no solo para indicar el estatus social de alguien, sino la capacidad social de hacer distinciones, de separar, de clasificar inteligiblemente el mundo: "El discurso de la cortesanía ofrece una visión global, diríase enciclopédica, del ser humano, al que imagina tanto en su constitución moral como en su apariencia fisica, en sus movimientos y en su comportamiento social" (Pedraza, 1999: 95). El objetivo de este dispositivo de control es naturalizar un sistema de diferenciación, jerarquizando las impresiones sensibles, distribuyéndolas en paquetes lógicos, significados, rutinas de comprensión aceptadas por todos. Entre sus metas podemos señalar su anhelo civilizador, es decir, "alejarse del salvajismo, de lo que crece a merced de la naturaleza" 40 , como los naturales de esta tierra.

El discurso de la gramática corporal del cortesanismo señorial también está atravesado por el discurso de la hispanidad. "La idea de establecer a través de la legua una conexión con el pasado español, como apunta Deas, es la que Ospina presenta en su Protocolo Hispanoamericano: la cortesanía castellana como lazo entre los países hispoanoamericanos, una hispanofilia que también para Uribe era el eje de la cultura tradicional colombiana" (Pedraza, 1999: 43) $)^{41}$.

39 En "El Proceso de la Civilización" (Elias, 1994) se ha cimentado una metodología de análisis que parte de la consideración socio y sico-genética de los mecanismos de autocoacción, los que serían responsables del progresivo endurecimiento de los factores que condicionan las sensaciones a un repertorio de posturas posibles, modales, reglas de etiqueta y en general, modos de comprensión y contención de los instintos del cuerpo en moldes sociales específicos.

40 (Pedraza, 1999: 99). Con lo cual las apreciaciones de Caro sobre el carácter intrínsecamente inferior y por consiguiente "malo" de todas aquellas costumbres disímiles a las de la tradición católica e hispánica cobran todo su sentido excluyente, totalizante.

41 Aquí pueden empalmarse los comentarios de Malcom en "El poder y la gramática" sobre los mecanismos de dominación linguistica en nuestro país durante el periodo señalado con la idea de la "personalidad histórica" Colombiana que propone Jaime Jaramillo Uribe: "Las ideas centrales de la concepción española [que marcan indeleblemente a 
A través de la urbanidad no sólo se definen los sexos, la clase social y las virtudes humanas; también se define la nacionalidad. A través de los usos se definen las cualidades hispanas y de la tradición latina:

"Así, recuerda que en España y en la América española se comió bien antes que en Francia, aconseja evitar las normas inglesas en la equitación y las formas afrancesadas en la correspondencia, y preferir la sobriedad y dignidad castellanas. Incluso en los negocios y el uso del teléfono debe rehuirse la llaneza de las costumbres norteamericanas" (Pedraza, 1999: 99).

Dentro del nuevo orden del discurso se insertan nuevas formas de presentarse ante el mundo. Estas nuevas formas atraviesan los cuerpos y las almas de la población colombiana durante el período de la Regeneración. La reformulación de las necesidades hace que el cuerpo y el alma se alimenten en distintas dosis del discurso moral reinante.

\subsubsection{Carencias Humanas}

El hombre, al igual que la sociedad, "no sólo tiene necesidades de riqueza, bienestar y prosperidad material, sino también de progreso intelectual y moral" (Caro, 1962: 704). De la dualidad de la configuración que nos dio la divinidad se desprende la complementariedad de tal dicotomía. Por un lado se agrupan las necesidades corpóreas que satisfacen los bienes materiales (riqueza, bienestar y prosperidad material); y por otro las necesidades que sacia la doctrina. Ambas se encuentran conectadas en un plano trascendente, ambas emanan de la voluntad de Dios al crear a su criatura preferida. Por esta razón:

"Satisfacer las necesidades físicas sin satisfacer las morales, es una degradación, una renuncia a la más bella porción de nuestra herencia; satisfacer las necesidades del alma sin dar lo justo a las del cuerpo, es una pretensión orgullosa, es un imposible. Lo uno es degradación; lo otro un arranque, aunque noble, de locura" (Caro, 1962: 705).

A pesar de considerar como "nobleza" el entregarse a las necesidades morales, califica este acto de locura (recordemos que arriba dijimos que

Colombia] de la vida son, quizá, la idea de persona y la de ser para la muerte, para la vida eterna. La persona, la personalidad, es la realidad más valiosa. Vale en todo caso más que la riqueza, y por eso no puede inmolarse ni ante el dinero, ni ante los bienes materiales que garantizan el bienestar". (Jaramillo, 1994: 66). 
la locura era una de las características de los de-centrados, de los que no tienen personalidad).

Recordemos que en los años inmediatamente anteriores al proceso de la regeneración, lo material, los sentidos eran vistos de manera distinta. El sensualismo de Tracy y el utilitarismo de Bentham habían ganado terreno dentro de los intelectuales liberales radicales de la época. La satisfacción de las necesidades corpóreas, materiales y la utilidad para el hombre son los fines de las sociedades y los hombres en la tierra. Ante esto hay que re-encausar la percepción del hombre y de la sociedad. Por ello se pregunta Caro:

“Cómo es posible dejar de reconocer en el hombre la legitimidad de aspiraciones más elevadas, la búsqueda de la experiencia mística, y de necesidades mucho más nobles que aquéllas cuya satisfacción no da por resultado sino la holgura y tranquilidad de sola nuestra parte animal?" (Caro, 1962: 678).

Al elevar las aspiracionnes vitales humanas, Caro participa de una reformulación, frente a la filosofía política del liberalismo, de la noción de "hombre". Ya no es solamente la salvación del alma (como en otros tiempos) o la satisfacción del cuerpo lo que importa. El cuerpo, lo físico, lo material, incluso lo económico, se re-encausan hacia el espíritu cristiano. La regeneración, en este sentido, es el rescate de las almas, las tradiciones y cultura colombiana arrebatada por el desenfreno de las pasiones.

Pero no solo el objeto y sujeto a satisfacer cambian, también varían las metas:

"La sana filosofía no puede estar en contradicción con el buen sentido; y el buen sentido reconoce no sólo una de estas dos clases de necesidad sino ambas; y no sin establecer diferencias: él ve en la satisfacción de necesidades físicas una condición de existencia sobre la tierra; en la de las morales, una condición de perfeccionamiento acá en la tierra, y un mérito para allá en el cielo" (Caro, 1962: 678).

El discurso del perfeccionamiento moral católico, con el que se quiere ocultar la penosa situación política y económica del país en éste periodo, es la regeneración, la cual, en palabras de Caro, es un proceso de rescate del alma de la nación Colombiana.

Este re-encauce/renacimiento del alma también involucra un reposicionamiento institucional. La Iglesia es un brazo importante que gestiona esta pretensión. Pero no solamente nos referimos al Concordato y a la delegación de la educación en la Iglesia ${ }^{42}$; nos referimos también a una

42 Este aspecto lo tratamos en el aparte denominado EDUCACIÓN Y GOBIERNO. 
práctica para-estatal en la que la Iglesia es la que se dedica a administrar la satisfacción de las necesidades, la administradora de la cuestión social.

La doctrina cristiana enseña que la mejor forma de distribuir los recursos, tanto materiales como morales, para la satisfacción de las necesidades es la limosna: "Con efecto, limosna es un don de satisfacer una necesidad..." (Caro, 1962: 704), nos dice Caro. Este don, manifestación de la caridad, es el mecanismo a través del cual la Iglesia ha procurado mantener la paz social. "Ella, inspirando el amor, consigue que cada uno posponga algo de sus naturales prerrogativas a favor de los mal dotados de fortuna: conocemos esta enseñanza con el nombre de misericordia" (Caro, 1962: 707).

Caro considera la propiedad como una cualidad intrínseca del hombre que la posee; ella es una "natural prerrogativa". Esta natural prerrogativa es reconocida por el derecho positivo como una manifestación de lo otorgado por la misericordia divina al hombre. La inequitativa distribución de los bienes operada por la Ley humana o Ley positiva ${ }^{43}$, es corregida por la misericordia, inscrita en el corazón del hombre y fomentada por la Iglesia. Es a través del amor y no de la guerra, las revoluciones o el mercado como se consigue el equilibrio social. Es por eso que la Iglesia "en vez de destronar a los reyes, saquear a los ricos, embrutecer a los sabios, los inclina a dar limosna de todo género: limosna de autoridad, de dinero y de ciencia" (Caro, 1962: 704-708).

Esta consideración de la paz social consolida una forma de ejercicio y administración de los recursos públicos, por intermedio de la Iglesia, que ya venía consolidándose en Colombia del siglo XIX. La alarma por la cuestión social y las clases peligrosas que se desató en Europa por esta época hace que las elites políticas, sobre todo conservadoras, pongan atención a este fenómeno. Todo lo anterior, aunado con la pretensión de los conservadores, sobre todo desde mediados del siglo XIX, de retomar la hegemonía política, y el descuido de los gobiernos liberales por la satisfacción de las expectativas de los desposeídos; dan como resultado una explosión de instituciones de caridad, manejadas en su mayoría por conservadores, que se disputan el control de los recursos estatales destinados a la "cuestión social".

43 Ver la opinión de Caro sobre la ley positiva en aparte de este trabajo denominado Hombre Público, La Persona como Modelo. 
Preocupados por este error estratégico los liberales se acercan a la Iglesia para procurar recuperar este campo táctico abandonado, incluso durante el periodo de hegemonía liberal radical ${ }^{44}$.

Vemos cómo en el discurso sobre las necesidades se teje todo un entramado de relaciones que buscan re-configurar de la personalidad de la nación. Se rescata la idea de "cuerpo" para insertar en él, a través de las normas de urbanidad, todo un régimen BIO-POLÍTICO y ya no solo letrado de dominación (Castro-Gómez, 2004: 185-200), naturalizando el discurso moral católico e hispánico. Un cuerpo se bisecciona, se divide en dos para, a través de la enunciación de sus necesidades, establecerle fines metafísicos. Un cuerpo que concebido como carente para que en el y por el se construya un aparataje administrativo que legitime una forma de gestionar la cuestión social, institucionalizando el devenir vital del cuerpo de los sujetos.

\subsubsection{El aspecto moral de la cuestión social}

En el aparte anterior abordamos lo que tiene que ver con las necesidades del hombre (dualidad cuerpo/alma), enunciando cómo se relacionan en la economía de la caridad. Ahora lo que pretendemos es trabajar cómo Caro dimensiona los conflictos sociales: "la cuestión social"45.

Las carencias o necesidades se encuentran en el mismo nivel, en el nivel humano. Por consiguiente, donde se analizan las carencias y necesidades materiales, estableciendo el desarrollo y bienestar de los pueblos, es por excelencia el campo económico. Caro analiza desde otro ángulo tales condiciones, asunto del estado social. A propósito de una discusión sostenida con Miguel Samper, podemos señalar el ángulo desde el que mira Caro el

44 "La Junta General de Beneficencia, creada en 1869 bajo los auspicios de la Sociedad de San Vicente de Paúl y del arzobispo de Bogotá, es el instrumento central de la política de apoyo oficial a las obras caritativas, a través de los presidentes liberales de la junta, como lo ilustra el caso de El Sapo Ramón Gómez, benefactor de la junta y gran artífice de la manipulación electoral liberal. Así, el proyecto del lazareto de Cundinamarca, cuya construcción en Tocaima esta prevista desde 1857, es confiado a la junta, con un presupuesto de 6.000 pesos anuales. En 1873 el Estado central asigna al nuevo estado de Bolívar una ayuda de 2.400 pesos anuales para fundar un nuevo lazareto. Las ayudas a hospitales, hospicios y asilos se multiplican a todo el país" (MARTíneZ, 2001: 417).

45 Tenemos que decir que el término "cuestión social" es acuñado por Rafael REYES y no específicamente por Caro, pero lo utilizamos porque hace alusión a lo que hoy denominamos conflicto social. 
"estado social": "Parado en mi anterior artículo el golpe con que la teoría del señor Samper amenazaba a la Compañía de Jesús, me permito en el presente, echar una ojeada general a nuestro estado social, que el escritor ha examinado más por menos bajo la fase económica” (Caro, 1962: 677).

La fase económica no es la adecuada para analizar los malestares o carencias de una sociedad. Ya dijimos que las necesidades, al igual que los hombres y las sociedades, reponden a dos dimensiones: la material y la social. Un análisis más acertado, en su opinión, debe dirigirse a ambos aspectos. Así, frente al escrito de Samper, titulado "Miseria en Bogotá" (Samper, 1867). Miguel Antonio Caro dice:

"Si el objeto que se propuso el señor Samper en su escrito, fue el de señalar la medicina del caso a los males que nos aquejan, hubiera sido de desear que no se hubiese embebecido tanto en la consideración de fenómenos netamente económicos de producciones y consumo; aspectos de la cuestión elucidados con el talento que suele, empero sin resultado alguno práctico" (Caro, 1962: 678).

Esta despreocupación por el aspecto económico del problema se debe a que las dos dimensiones antes mencionadas (los males, humanos y sociales) son producto de la corrupción moral:

"La dolencia es síntoma o anuncio de un mal, no el mal mismo, y dolencias son los fenómenos que analiza el señor Samper. En vano es manifestar los feos retoños de una enfermedad cuyo carácter no se especifica. La miseria es una de las de las manifestaciones de la falta o mala dirección de la humana actividad, y la actividad humana es el resultado de uso o abuso de la libertad. Así la cuestión económica queda subordinada a la cuestión moral" (Caro, 1962: 678).

Es el ejercicio abusivo de la libertad la que lleva a la degeneración, a la perversidad; y una vez escogido este camino el malestar pronto se hace sentir. Recordemos que Caro se inscribe en la escuela del libre albedrío: "El libre albedrío, considera que todo hombre que está en uso de sus facultades puede hacer que su voluntad resista a los impulsos (...), o mejor, que él es dueño de obrar o no obrar y por lo mismo responsable de sus acciones" (Medina, 1921). Según esta posición, Dios le otorgó al hombre la posibilidad de razonar y de elegir, y por lo tanto el hombre es libre, pero también responsable de sus actos, por ello es sujeto de castigo ${ }^{46}$.

46 La posición de Caro al respecto se encuentra en ente trabajo en el aparte denominado Dimensión Lingüística. 
El mal uso de la libertad se deriva de las falsas doctrinas, en nuestro caso, de acoger el liberalismo, la masonería, el sensualismo filosófico a ultranza, etc. Doctrinas predicadas por los falsos sacerdotes que ven aunada la libertad con la utilidad. Así se pregunta Caro:

“Cómo quieren que el artesano, ser inteligente y libre, acepte el deber de respetar la abundancia del rico y el poder del gobernante, viviendo asido y poco productivo su trabajo, si se le presenta como único fundamento de ese deber la utilidad, no la suya sin duda, supuesto que muchas veces el hambre llama a su puerta convidándole a desesperadas revoluciones?" (Caro, 1962: 678).

El malestar social, entonces, y la pobreza extrema en que se encuentran las poblaciones rurales y urbanas de la época es, según Caro, el producto de la violación del orden natural debido a la liberalidad y falta de buen sentido de la actividad de las sociedades. Esto se confirma con la siguiente apreciación de Caro: "Digo que la cuestión del malestar social es una cuestión moral, supuesto de aquél depende de la violación del orden, que es ley de Dios, y la violación del orden es una determinación de la voluntad humana" (Caro, 1962: 679).

Extrañísima postura que llevaría a pensar que de cumplirse juiciosamente la ley de Dios, la prosperidad material debería sobrevenir por añadidura, posición ésta propia del protestantismo, según el estudio de Weber sobre "el espíritu del capitalismo" y las prácticas ascéticas de esta religión. Con lo que Caro acabaría por equiparar el bienestar económico, mundano, terreno, con la prosperidad espiritual.

"El mal social es la violación del orden social. Pero el orden social tiene dos semblantes: podemos considerarle como ley natural, es decir, como manifestación mediata de la ley de Dios en la naturaleza misma de las relaciones humanas, y como revelación inmediata de Dios al espiritu humano. O de otro modo: en el desarrollo de la actividad social, como en el de la individual, se observan dos órdenes de fenómenos: el uno impuesto por la necesidad, por la naturaleza misma; el otro es de más elevada alcurnia, porque viene del amor de Dios y florece de acciones benévolas" (Caro, 1962: 680).

El segundo semblante es el que Caro asume y frente a él legitima las penurias de cualquier sociedad bajo un gobierno liberal, ya que la búsqueda de la utilidad como criterio moral supremo genera un empobrecimiento tanto material como espiritual del hombre. En este tipo de régimen, por ejemplo, el amor que predica la Iglesia para restablecer las relaciones sociales no 
surte efecto: "la figura del camello y de la aguja es símbolo de esa misma justicia divina" (Caro, 1962: 663).

Como ya dijimos, el remedio efectivo de la cuestión social es el amor que permite a los hombres desprenderse de sus posesiones naturales. Lo contrario sería atenerse a la solución socialista del asunto, lo que, para nuestro autor, llevaría ineludiblemente a la guerra.

"Parto de un hecho: la no apropiación de los bienes esencialmente limitados es causa de guerra entre los hombres. Cuando el poder público no está apropiado, la ambición trae guerra. Cuando la mujer no lo está, el amor y los celos traen la guerra. Cuando la tierra y la riqueza no lo están, la codicia y la necesidad hacen la guerra" (Caro, 1962: 681).

La propiedad, en este orden de ideas, es una condición natural a la que deben estar sometidos los objetos. Si alguno no se halla en cabeza de un sujeto que pueda centrarlo en su persona y gobernar soberanamente sobre él, esto genera la guerra. Causa de ello no es solamente el que los objetos estén por allí "libres", tentando a muchos hombres, sino también el que se arrebate su propiedad de manera abrupta, que no haya medios legítimos de desprendimiento, como la misericordia. Esta ilegitimidad, entre otras cosas, es de la que culpa a los liberales radicales al expropiar a la Iglesia los bienes denominados “de manos muertas". Por ello, además de adoctrinar en el falso credo del utilitarismo, culpa a los liberales radicales del malestar social.

Pero además de lo anterior, Miguel Antonio Caro lanza tres críticas más sobre este tipo de soluciones. Dice: "Aplicado ese absurdo sistema a la reforma social, hallamos: $1^{\circ}$ ) que hay desigualdades cuya eliminación es materialmente imposible de obtener; $2^{\circ}$ ) que anuladas unas, se producen otras nuevas; $3^{\circ}$ ) que desaparecidas desigualdades, desaparecen con ella no sólo sus inconvenientes, pero también sus ventajas" (Caro, 1962: 687).

Como ejemplo de la tercera encontramos la desigualdad entre padres e hijos. Señala los posibles abusos que sobre el hijo puede cometer el padre. El padre no tiene derecho a maltratarle ni a mutilarle, "El padre no tiene derecho a privar al hijo del alimento necesario para su desenvolvimiento físico; tampoco podrá por lo mismo quitarle lícitamente el alimento moral" (Caro, 1962: 687). El padre puede decidir qué instrucción o credo profesar, más no de cercenar la misma posibilidad de creer. Por ello, el aparejar derechos, en el ámbito familiar, puede traer como inconveniente el resquebrajamiento de la familia y el libertinaje de los hijos. 
Sobre la segunda crítica señala la ineficacia de la superioridad numérica como forma de igualar en la política o en la ciencia. Realizando, a través de una analogía, un cuestionamiento al sistema democrático:

"La razón y la bondad son cosas inmateriales que no pueden medirse con la vara material del número. Ningún litigio, civil, literario o cientifico, se dirime midiendo a los contrincantes para decidir a favor del más alto o el más grueso; lo mismo da decidir a favor del partido más numeroso, es decir el más grueso" (Caro, 1962: 689).

Como corolario de lo anterior tenemos que el conflicto y la desigualdad son necesarios para el mantenimiento de la soberanía de la propiedad. Además, "si no existieran grandes diferencias sociales, no habría ocasión a que el poderoso ejerciera actos de benevolencia y caridad, y el pequeño, de resignación y agradecimiento" (Caro, 1962: 690). Sin estos actos de benevolencia y resignación, ¿cómo se cumplirían los fines del hombre en la tierra?, ¿cómo harían, ricos y pobres, para poner a prueba sus actos, para hacer votos, para ganar el cielo?

La única solución verdadera que profesa Caro es la benevolencia, en donde la Iglesia es la "administradora" por excelencia de las limosnas materiales (por medio de los auspicios, hospitales, instituciones de beneficencia, etc.) y morales (como única institución de adoctrinamiento).

Podemos decir, en síntesis, que la cuestión social para Caro refuerza sus ideas sobre la necedad y la rectificación de la moral en las que se legitima su tarea como regenerador. El mal, el contagio de las ideas del utilitarismo condujo a la perversión moral que produce el estado crítico social. El malestar producido por la doctrina de los falsos profetas desencadenó la guerra, el desconocimiento del orden natural y de los derechos soberanos. Esto condujo a la sociedad y al Estado al irrespeto de los derechos naturales (la propiedad) y por ende al caos. Las soluciones "socialistas" que proponen los utilitaristas, además de desencajar el equilibrio social que reproduce el respeto al orden, desestabiliza los fines del paso por la tierra y deja al hombre como única alternativa apegado al "orden material".

\subsection{VOZ, RACIOCINIO Y ANIMALIDAD}

En otro aparte de este texto decíamos que a los descentrados, a los liberales radicales, a la oposición, el régimen Regenerador les quito la voz, la herramienta más importante que tenían para expandir su doctrina. 
Además, decíamos que Caro caracterizó a los descentrados como seres que susurran, que hacen ruido pero que no pueden transmitir palabra ni idea alguna. Ahora vamos a profundizar esta apreciación.

La palabra, según Caro, es un don que dio Dios a los hombres para que pudieran hablar, razonar y discutir; pero su uso, aunque dentro del marco de la libertad, se encuentra limitado por la verdad, que es el fundamento de toda doctrina. "Si la palabra no es libre, no hay progreso, pero si esa libertad no respeta la verdad, en vez de progreso habrá lamentables extravios" (Caro, 1962: 1286).

En este sentido la discusión no tiene por ánimo construir la verdad sino develarla, desentrañarla o librarla de las tergiversaciones de los falsos profetas. La palabra es uno de los atributos fundamentales del hombre, pero como es un don que emana de Dios su uso requiere cierto cuidado: debe repetir la la verdad que El Creador mismo produce. Al respecto Caro afirma: "Ni se concibe hombre sin palabra, ni palabra sin discusión, por supuesto que discusión racional, es decir, discusión que parta del amor de la verdad" (Caro, 1962: 1287).

Queda claro que aquí la idea de Verdad es absoluta, eterna e incuestionable; como corresponde a una concepción dogmatizante, teológicamente hablando, del mundo y de las maneras tanto colectivas como individuales de darle sentido. Entender los acontecimientos al circunscribirlos a un marco categorial dado por descontado. Se trata, en consecuencia, de tomar los criterios de verdad y reificarlos en el intento de consolidar una perspectiva, un ángulo enunciativo.

La palabra, además, la relaciona nuestro autor con un atributo que se desprende de la transmisión del apostolado de la iglesia. "Ego vici mundum, dijo el Verbo Divino: la palabra ha vencido al mundo. Jesucristo con su palabra hizo apóstoles, lo apóstoles con su palabra hicieron cristianas las gentes, y hoy, destituidos de toda arma que no sea la palabra, los católicos esperamos por la palabra, Dios mediante, restaurar el reinado social de Jesucristo" (Caro, 1962: 1286-87). Esta genealogía del Verbo, legitima la posición según la cual la enunciación y predicación de la verdad es una facultad exclusiva la Iglesia.

Otra aproximación puede hacerse desde la frase "y el verbo se hizo carne", título de la colaboración de Zandra Pedraza al proyecto colectivo "Pensar el siglo XIX”' (Castro-Gómez, 2004: 185-200), partiendo de la siguiente idea: "se ha obtenido amplio consenso en torno a la idea de que el apego a 
la letra y el vínculo entre los letrados y el poder fue el fundamento de una ciudad escrituraria reservada a una estricta minoría" (Castro-Gómez, 2004: 186). Frente a esta evidencia historiográfica, se busca estudiar

"cómo el ejercicio del poder letrado se ocupó durante el siglo XIX del gobierno de la vida y cómo este ejercicio modificó el corpus de recursos semánticos adoptados por el pensamiento social nacional. Su uso fracturó el régimen de representación letrado, aquel legado por la colonia en forma escrituraria, y dio paso a un régimen bio-político cuya norma proviene del corpus interpretativo de la biología, fija su atención en la vida, procura explicar sus reglas y se distingue del régimen de los discursos literarios" (Castro-Gómez, 2004: 186).

Con lo anterior se intenta quebrar la presuposición básica que los historiadores han elaborado para la comprensión de este período de la historia colombiana. Consideramos que no se trata propiamente de una ruptura, sino de dar mayor nitidez a una hipótesis como la de Malcom Deas, mencionada en el aparte de este trabajo titulado Miguel Antonio Caro, Sofista, (Deas, 1993: 25-60), ya que no se descarta que el ejercicio de la dominación estuviera fuertemente ligado al poder de la palabra con todo su arsenal de recursos poéticos, estilísticos y gramaticales; acaparados por una élite intelectualmente fuerte, hispanofílica y en la mayoría de los casos católica; sino que Pedraza afirma que estos esquemas formales, propios del período colonial, tomaban la forma concreta (el "ideal de lo práctico") de dispositivos de gestión bio-política de la existencia, en los términos señalados en la cita que acaba de hacerse.

Este acercamiento incontaminado, prístino, "higiénico" a la verdad, este amor por la misma, constituye el principio por el cual Caro divide a los hombres en dos: los brutos y los hombres de verdad.

"Los brutos no hablan porque no raciocinan, no lo necesitan, pues sus relaciones las fija no la fuerza de la verdad, sino la realidad de la fuerza. El león, que es poderoso y lo será siempre, no necesita sino del rugido, signo permanente de su superioridad sobre el cordero (...). Entre los brutos sólo la fuerza triunfa, entre los hombres la verdad es quien debe triunfar, la verdad que lucha por medio de la palabra" (Caro, 1962: 1286).

Los brutos son los descentrados, los federalistas, los irracionales, los que condujeron al país a la anarquía y al despotismo; ellos son los que niegan el ejercicio de la palabra: "Como el despotismo es la fuerza que suplanta al derecho, claro es por su naturaleza, que el despotismo tiende a crear el silencio" (Caro, 1962: 1287). Este silencio es de dos clases, el del oprimido y el del opresor. 
"El opresor que posee la fuerza y, poseyéndola, cree poseer así mismo el derecho, que equivoca la una con el otro, que confía en aquella y de éste se ríe... El oprimido, que no confunde la fuerza con el derecho, protesta contra la fuerza en el nombre del derecho, (...) pero muchos se sienten aterrados, confundidos delante de la fuerza o la caprichosa fortuna, que no es más que una forma ciega de la fuerza, y oprimidos callan y se resignan, como se resigna y calla la materia oprimida en las prensas inventadas por la industria moderna" (Caro, 1962: 1287).

El uno lo caracteriza como silencio tiránico, el otro como silencio servil, pero ambos producidos por el envilecimiento de la opresión.

“Callan, pues los opresores por que teniendo el poder, ultima ratio, les da pereza hablar para alegar razones secundarias a la razón de la fuerza, suprema para ellos. Y callan asimismo los siervos, porque les da miedo hablar y alegar su derecho, que es para ellos ínfima razón" (Caro, 1962: 1289).

Esta situación produce voces animalizadas, glosolalia, confusión babélica trastornante, que al estilo de la fábula, representa solo el crujir de dientes de una tragedia anunciada en donde,

"el león dice: ;Yo soy fuerte! Y el cordero, presa del pánico dice ;Yo que te hice! estas palabras, apropiadas por la fábula a los brutos, no son más que una interpretación intelectual en las voces dadas por Dios a cada especie: el rugido del león, el balido al cordero: ;Yo soy fuerte! Es el sentido del rugido del león; ;Pobre de mí! Es la significación del valido de la oveja. Nada de eso es digno del hombre, ni el yo soy fuerte del león, ni el pobre de mí, de la oveja" (Caro, 1962: 1290).

Del hombre, por el contrario, se espera un diálogo inteligente, racional, en el que la verdad es a la vez el origen, el "punto cero" ${ }^{47}$ y el horizonte o meta de cualquier elucubración u operación del intelecto. Ella debe subordinar la fuerza a la palabra, de otra forma la verdad, que es la forma en que se manifiesta la ley de Dios, se ve agredida. La sociedad que subordina, por opresión o por miedo, la verdad a la fuerza es una sociedad en donde la animalidad reina: "Una sociedad en que asi se habla es una sociedad verdaderamente animalizada" (Caro, 1962: 1290), pre-política en términos Aristotélicos, no viable para un modelo de civilización que establece una clara - e inobjetable-distinción entre lo bueno y lo malo y para la cual, estas dicotomías presentan un carácter inamovible. Se trata de una forma histórica

$47 \quad$ Ver nota 1. 
de Discurso que, como cualquier otra NATURALIZA SUS CUADROS CLASIFICATORIOS, asignándoles un valor irrebatible.

Esta "animalización" para Caro es suscitada por el hecho de que los liberales amenazaron, entre otras instituciones, a la propia Iglesia, que es la cuna de la verdad:

"El señor arzobispo no puede hablar, y la razón es, que si habla, será oprimido y oprimida la iglesia que rige. Y esto se le intima, y en nombre no del escritor sino del partido liberal entero, de quien el escrito cree autorizado e infalible vocero. He aquí, pues, renaciente la razón de la fuerza" (Caro, 1962: 1291).

También, y consecuente con lo aquí enunciado, el gobierno liberal de turno priva de la voz animalizada, del susurro, a la oposición (no les quita nada porque nunca han tenido voz, según se ha venido afirmando). Si se expresan por los periódicos es

"por que es derecho natural el deber legal de reprimir todo abuso, y siendo la prensa un instrumento, como hay otros muchos, que lo mismo sirve para hacer el bien que el mal, no se concibe que solo por el contacto de este instrumento, aunque especial, los actos humanos más detestables hayan de adquirir la naturaleza de buenos o de indiferentes" (Caro, 1991: 101).

Así las cosas, "el sistema preventivo que ese artículo autoriza consiste en poder impedir una publicación, o sea en el ejercicio de la previa censura; esta para evitar la confabulación que se preparaba en contra del gobierno" (Caro, 1991: 101).

De allí, precisamente, la necesidad de derogar a los gobiernos despóticos, que arraigan la animalidad en el corazón y en el entendimiento, imponiendo sentimientos antirreligiosos en la boca de las gentes:

"Vemos: en medio de un pueblo católico se forman, a la sombra de la paz y de la tolerancia, una escuela anticatólica que se arroga el derecho de enseñar, que pretende enseñar lo que ella quiere y lo que no quiere el pueblo, que impone esa instrucción al pueblo si no la acepta ¿No es ésta una escuela, una institución eminentemente despótica cual nosotros la hemos calificado? Tenemos, pues, derecho de calificar de déspotas, o al menos de fragmentos de déspota, a los directores y miembros de esa funesta y costosa institución" (Caro, 1962: 1305).

Para cerrar este acápite podemos decir que el discurso y el significado que se atribuye a la voz no es simplemente un enunciado enciclopédico de un manual de lingüística. La voz es un elemento que caracteriza al hombre, un don dado por Dios para que por ella discurran la elucubraciones que 
revelen la verdad. El silenciamiento de este dialogo legitima a las gentes para que se levanten en contra del régimen y se Regenere el uso de la palabra. Regeneración entendida como "elevación" continua desde el murmullo indistinguible de un multitud balbuciente, que progresivamente, y solo por la gracia de Dios - mereciéndose ese milagro al cumplir obedientemente los deberes de la moral católica-, va alcanzando niveles de orden regidos por los principios cristianos de uso de la palabra: "no jurar en vano", "amar a Dios sobre todas las cosas", etc.

\subsection{CONCLUSIONES}

Pudimos ver en este recorrido por algunos aspectos cruciales del Discurso de Caro, el modo cómo operaron en contextos específicos aglutinantes simbólicos o categorias que, como el caso de la hispanofilia, contornearon un dispositivo de dominación lingüística en nuestro territorio.

Desde la apreciación de Caro como sofista, en la que es difícil discernir al portavoz de la Verdad del embaucador, el Dialéctico que solo busca la verdad y el sofista que construye apariencias en el despliegue de un arsenal argumentativo brillante y por supuesto falaz, o por lo menos inconsistente con sus propias premisas. Desde allí atisbamos algunos momentos claves en el proceso histórico de construcción de la personalidad, y que tienen que ver directamente con la concepción de historia que maneja Caro, interesada en "monumentalizar" y hacer la apología de un pasado español glorioso, en detrimento de un mundo pre-hispánico insignificante o simplemente invisibilizado.

En este orden de ideas, El llamado Orden Católico campeó en el medio-ambiente simbólico de finales del siglo XIX como atmósfera de obligada referencia para definir lo bueno y lo malo durante el período de la regeneración. Lo que, con el ejemplo de un Andrés Bello superlativo y mitificado, completa el mapa epistemológico de un orden discursivo autoritario, que personaliza a los sujetos en orden a reprenderlos, con el objetivo de asignarles una culpabilidad (congénita, un sentimiento de falta que constituye al sujeto como tal) y proceder a establecer así una estrategia de dominación discursiva, que en muchos aspectos, si consideramos la miseria creciente de las personas marginadas desde finales del XIX hasta nuestros días, permanece incólume en muchos aspectos. Si bien matizado el contenido específicamente católico, sí remozado como agenciamiento 
colectivo de enunciación para el que naturalizar las diferencias sociales, según un concepto dado de Persona, es una tarea políticamente insoslayable.

\section{BIBLIOGRAFÍA}

\section{Clave:}

FP. Fuente Primaria.

FS. Fuente Secundaria general.

FSc. Fuente secundaria conceptual.

FSh. Fuente secundaria historiográfica.

FShp. Fuente secundaria historiográfica sobre el período (s. XIX)

AP. artículo de publicaciones periódicas

AP. Aguilera, M. (1950). "Las ideas estéticas de Miguel Antonio Caro". En: Revista de Indias abril-Junio. Bogotá.

FSc. Agamben, G. (2001), [1977]. Estancias, la Palabra y el Fantasma en la Cultura Occidental. Valencia: Pre-textos.

FShp. Arango, R. (2002). "La Construcción de Nación”. En: Miguel Antonio Caro y la Cultura de su Época. Rubén Sierra Mejía. Bogotá: U. Nacional.

FSh, Archila, M. (2003). Idas y Venidas, vueltas y revueltas, protestas sociales en Colombia (1958-1990)). Bogotá: ICANH, CINEP.

FShp. Arismendi, I. (1989). Presidentes de Colombia. Bogotá: Planeta.

FSc. Aristóteles (2000a). Retórica Madrid: Alianza.

FSc. Aristóteles (2000b). Política. Madrid: Alianza.

FSh. Aróstegui, J.(1995). La Investigación Histórica, Teoría y Método. Barcelona: Crítica.

FS. Asturias, M. A. (1975). Hombres de Maiz. Buenos Aires: Lozada.

FS. Asturias, M. A. (1999). Leyendas de Guatemala. Madrid: Cátedra.

FS. Bacon (1996). Bacon, Retratos y autorretratos. Madrid: Debate.

FSc. Balandier, G. (1994) [1992]. El Poder en Escenas, de la representación del poder al poder de la representación. Barcelona: Paidós.

FSc. Benjamin, W.(1971). Ángelus Novus, Barcelona; Edhasa.

FSc. Blanchot, M. (1992). El espacio literario. Barcelona: Paidós.

FSc. Blanchot, M. (1990). La escritura del desastre. Caracas: Monte Avila.

AP. Boletín Cultural y Bibliográfico del Banco de la República (1979). La lengua española y Miguel Antonio Caro, Vol. 16, Nº. 6, Bogotá.

FShp. Bonilla, M. A. (1948). Caro y su obra. Bogotá: Imprenta Nacional. 
FS. Borges, J. L.(1989). Obras Completas T.I. Barcelona: Emecé

FSh. Cabrera, M. Á. (2001). Historia, Lenguajey Teoría de la Sociedad. Madrid: Cátedra. FSc. Cacciari [1986] (1989). El Ángel necesario. Madrid: Visor.

FSc. Cardenas, C. A. (2002). La persona, solitario social en Tomás de Aquino. Bogotá: U. Santo Tomás.

FP. Caro M. A. (1962). Obras (T.I). Bogotá: Instituto Caro y Cuervo.

FP. Caro, M. A. (1980). Obras (T. III). Bogotá: Instituto Caro y Cuervo

FP. Caro M. A. (1990a). Escritos políticos. (Primera serie). Bogotá: Instituto Caro y Cuervo.

FP. Caro, M. A. (1990b). Escritos Políticos (Segunda serie). Bogotá: Instituto Caro y Cuervo.

FP. Caro, M. A. (1991). Escritos Políticos (Tercera serie). Bogotá: Instituto Caro y Cuervo.

FP.Caro, M. A. (1986a). Estudios constitucionales y jurídicos (Primera serie). Bogotá: Instituto Caro y Cuervo.

FP. Caro, M. A. (1986b). Estudios constitucionales y jurídicos (Segunda serie). Bogotá: Instituto Caro y Cuervo

FP. Caro, M. A. (1981). “Bello era Católico". En: Escritos Sobre Don Andrés Bello. Bogotá: Instituto Caro y Cuervo.

FP. Caro, M. A. (1981). "Ojeada a las Opiniones Políticas y Religiosas de Don Andrés Bello". En: Escritos Sobre Don Andrés Bello. Bogotá: Instituto Caro y Cuervo.

FP. Caro, M. A. (1986). "División Territorial”. En: Estudios constitucionales y jurídicos. Primera serie. Bogotá: Instituto Caro y Cuervo.

FP. Caro, M. A. (1990). "Conmutación de Pena de Muerte". En: Estudios Constitucionales y Jurídicos. Segunda Serie. Bogotá: Instituto Caro y Cuervo.

FP. Caro, M. A. (1990). "Historia y Filosofía". En: Estudios constitucionales y jurídicos. Segunda serie. Bogotá: Instituto Caro y Cuervo.

FP. Caro, M. A. (1990). "Imperio de la Legalidad". En: Estudios constitucionales y jurídicos. Primera serie. Bogotá: Instituto Caro y Cuervo.

FP. Caro, M. A. (1990). "Inmunidad del Presidente". En: Estudios constitucionales y jurídicos. Primera serie. Bogotá: Instituto Caro y Cuervo.

FP. Caro, M. A. (1990). "Política Nacional”. En: Estudios constitucionales y jurídicos. Segunda serie. Bogotá: Instituto Caro y Cuervo.

FP. Caro, M. A. (1990). "Tradición Unitaria”. En: Estudios constitucionales y jurídicos. Segunda serie. Bogotá: Instituto Caro y Cuervo. 
FP. Caro, M. A. (1991). “Alocución”. En: Escritos Políticos. Tercera Serie. Bogotá: Instituto Caro y Cuervo.

FP. Caro, M. A. (1991). Concepto Constitucional de la Representación en Escritos Políticos. Bogotá: Instituto Caro y Cuervo.

FP. Caro, M. A. (1991). "Posesión de la Vicepresidencia de la República Discurso de Posesión Ante el Congreso". En: Escritos Políticos. Tercera Serie. Bogotá: Instituto Caro y Cuervo.

FP. Caro, M. A. (1996). "Educación Religiosa". En: Escritos Constitucionales y Jurídicos. Primera Serie. Bogotá: Instituto Caro y Cuervo.

FSh. Carr, E. (1987). ¿Qué es la historia? Barcelona: Ariel.

FSc. Castro-Gómez, S. (2004). Pensar el Siglo XIX. Cultura, Biopolítica y Modernidad en Colombia. Pittsburgh: Instituto Internacional de Literatura Hispanoamericana, Pensar, U. Javeriana.

FS. Castro-Gómez, S. (2005). La Hybris del Punto Cero. Ciencia, Raza e ilustración en la Nueva Granada (1750-1816). Bogotá: Pensar, U.Javeriana.

FSh. Colmenares, G. (1987). Las convenciones contra la cultura. Bogotá: Tercer Mundo.

FSp. Copello Faccini, A. (1959). La filosofia política de Miguel Antonio Caro. Bogotá: Colegio Mayor de nuestra señora del Rosario, Facultad de jurisprudencia.

FSh. Costa, R. y Mozejko, D. (2001). El Discurso Como Práctica, Lugares desde donde se escribe la Historia. Buenos Aires: Homo Sapiens.

FShp. Cubides, F. (2002). “Territorio, Nación y Sociedad”. En: Miguel Antonio Caro y su época. Editor. Rubén Sierra Mejía. Bogotá: Universidad Nacional de Colombia.

FShp. Deas, M. (1993). Miguel Antonio Caro y amigos: gramática y poder en Colombia, en del poder y la gramática. Bogotá: Tercer Mundo.

FSc. Deleuze, G. (1994) [1969]. Lógica del Sentido. Barcelona: Paidos.

FSc. Deleuze, G. (1998) [1969]. El Antiedipo. Barcelona: Paidos.

FSc. Deleuze, G. (1994), [1983]. La imagen-movimiento. Estudios sobre cine 1., Barcelona: Paidós.

FSc. Deleuze-Guattari (1997). Mil Mesetas, Capitalismo y Esquizofrenia. Valencia: Pre-textos.

FSc. Derrida, J.(1989). La Escritura y La Diferencia. Barcelona: Anthropos.

FSc. Derrida, J.(2004). Acabados. Madrid: Trotta.

FSc. Derrida, J. (1997). La Diseminación. Madrid: Espiral-Fundamentos.

FS. Desclée de Brower (1969). Biblia de Jerusalén ilustrada Barcelona: Nauta 
FShp. Diaz, M.(1984). La vida de don Miguel Antonio Caro, Bogotá: Instituto Caro y Cuervo.

FSc. Echeverri, Á. (2002). Teoría Constitucional y Ciencia Política. Bogotá: El Profesional.

FSc. Elias, N. (1994). El Proceso de la Civilización: México: F.C.E.

FSh. Elton, G.R (1961). The Practice of History. London-Glasgow: Collins and Fontana Library.

FSh. Evans, R. (1997). In Defence of History, Granta Books, London, 1997.

FShp. Florez, R. D. (2001). Un imperio retórico de cien años, en Palimpsestus. Bogotá: Universidad Nacional de Colombia, Facultad de Ciencias Humanas

FSc. Foucault, M. (2000). El pensamiento del afuera, Valencia: Pre-textos.

FSc. Foucault, M. (1997) [1970]. Arqueología del saber. México: Siglo XXI.

FSc. Foucault, M. (1995). Vigilar y Castigar. México: Siglo XXI.

FSc. Foucault, M. (1992). El Uso de los Placeres. México: Siglo XXI.

FSc. Foucault, M. (1992). La Historia De La Sexualidad T. II, México: Siglo XXI.

FSc. Foucault, M. (1992). La Inquietud de Si: México: Siglo XXI.

FSc. Foucault, M. (1999) [1970]. El Orden del Discurso. Barcelona: Tusquets.

FSc. Foucault, M. (1996). Las Tecnologías del yo. Barcelona: Paidos.

FSc. Foucault, M. (2004). La Hermenéutica del Sujeto. México: F.C.E.

FSc. Foucault, M. (1993) [1968]. las palabras y las cosas. México: Siglo XXI

FSc. Foucault, M. (1997) [1968]. La arqueología del saber. México: Siglo XXI

FSc. Freud, S. (1984). Moisés y el Monoteísmo. Madrid: Amorrortu.

FS. Fuentes, C., (1997). Todos los gatos son pardos. Mexico: Siglo XXI.

FShp. Guillén, F. (1986). La Regeneración. Primer Frente Nacional. Bogotá: Carlos Valencia.

FSc. Gell-Man, M. (1996). El Quark y el Jaguar, Madrid: Anagrama.

FShp. Gonzáles, J. E. (2005). Legitimidad y Cultura, Bogotá: U. Nacional de Colombia, Centro de Estudios Sociales CES.

FSh. Gruzinski, S.[1990] (2001). La Guerra de las imágenes, de Cristóbal Colón a "Blade Runner". México: F.C.E

FSc. Habermas, J. (1996). El Discurso Filosófico de la Modernidad. Madrid: Taurus. FSc. Hardt, M. \& Negri, A.(2001). Imperio, Barceloma: Paidós.

FShp. Hernández, I. (1968). Miguel Antonio Caro, vida y obra. Bogotá: Instituto Caro y Cuervo. 
FSc. Huxley, A. (1995). Las puertas de la percepción. Barcelona: Edhasa.

FShp. Jaramillo, J. (1994). La Personalidad Histórica de Colombia". Bogotá: El Áncora.

FShp. Jaramillo, J.(2001). El pensamiento colombiano en el siglo XIX. Bogotá: Alfaomega.

FSh. Jenkins, K. (1995). On What'S History. London: Routledge.

FShp. Kalmanovitz, S. (2002). "Miguel Antonio Caro, El Banco Nacional y el Estado". En: Miguel Antonio Caro y su época. Ed. Rubén Sierra Mejía. Bogotá: Universidad Nacional de Colombia.

FShp. Kalmanovitz. S.n (2003). Economía y Nación. Bogotá: Norma.

FShp. König, H.-J. (1994). El Camino Hacia la Nación. Nacionalismo en el Proceso de Formación del Estado y de la Nación de la Nueva Granada, 1750-1856. Bogotá: Banco de la República.

FShp. Laguado, A. C. (2004). Pragmatismo y Voluntad. Las Ideas de la Nación de las Élites en Colombia y Argentina. 1880-1910. Bogotá: Universidad Nacional de Colombia.

FSh. Lloyd, C. (1993). The Structures Of History. Cambridge: Blackwell.

FSc. Llinas, R. (2003). El Cerebro y el Mito del Yo. Bogotá: Norma.

FShp. López, L. (1944). Miguel Antonio Caro y Rufino José Cuervo. Bogotá: El Gráfico.

FSc. Lotman, I. (1996). La Semiosfera, Semiótica de la Cultura y del Texto. Madrid: Cátedra.

FS. Lovecraft H. P., (1992) [1971]: Viajes al Otro Mundo, Ciclo de Aventuras Oníricas de Randolph Carter. Madrid: Alianza.

FSc. Lozano, J.; Peña-Marin, C. \& Abril, G. (1999). Análisis del discurso, Hacia una semiótica de la interacción textual. Madrid: Cátedra.

FSc. Luhmann, N. (1997). Modernidad y complejidad. Madrid: Trotta.

FSc. Lyotard, J.F. (1989). La Condición Posmoderna. México: Cátedra.

FSc. Maturana \& Varela (2004). El árbol del conocimiento. Madrid: El debate.

FShp. Martínez, F. (2001). El nacionalismo cosmopolita. La referencia europea en la construcción nacional colombiana. Bogotá: Banco de la República/ Instituto Francés de Estudios Andinos.

FShp. Mcgreevey, W. (1979). Historia económica de Colombia. Un debate en marcha. Bogotá: Banco Popular.

FSh. Medina, H. (1921). La Imputabilidad Inimputabilidad en el Proyecto de Código Penal del Doctor Jose Vicente Concha. Bogotá: Minerva. 
FShp. Melo, J. O. (1989). Nueva Historia de Colombia (Tomo I). Bogotá: Planeta. FSc. Morin, E. (1998). El método T. IV Las ideas, su hábitat, su vida, sus costumbres, su organización. Madrid: Cátedra.

FShp. Munera, A. (1998). El fracaso de la nación. Región, clase y raza en el caribe colombiano (1717-1810). Bogotá: El Ancora.

FSc. Nietzsche, F. (1997). Asi Habló Zaratustra. Madrid: Alianza.

FSc. Nietzsche, F.(1932). Obras completas, T. V. Madrid: Aguilar, 1932.

FSc. Nietzsche, F. (1996) [1884-1888], Fragmentos póstumos. Bogotá: Norma.

FSh. Ocampo, J. A. (1989). "Los orígenes de la industria Cafetera 1830-1929". En: Nueva historia de Colombia (T. V). Bogotá: Planeta.

FSc. Pardo, J. L. (1992). Las formas de la exterioridad. Valencia: Pre-textos.

FSc. Pastor, B. (s.f.). Discurso Narrativo de la Conquista de América.

FS. Paz, O. (1982). Sor Juana Inés de la Cruz o las trampas de la fe. México: F.C.E.

FSc. Paz, O. (1994). EL Arco y la lira. México: F.C.E.

FShp. Pedraza, Z. (1999). En cuerpo y alma. Visones del progreso y de la felicidad. Bogotá: Universidad de los Andes.

FSc. Pewzner, E. (1996). El Hombre cupable, la locura y la falta en occidente. México: F.C.E.

AP. Porras, G. (1948). “Caro Razonador". Publicado en: Thesaurus, boletín del instituto Caro y Cuervo. Bogotá.

FSc. Portilla, M. (1986). Literatura del México antiguo. Caracas: Ayacucho.

FSc. Portilla, M. (1972). Visión de los vencidos. México: Biblioteca del Universitario.

FSc. Portilla, M. (1996). El destino de la palabra, De la oralidad y los códices mesoamericanos a la escritura alfabética. México: F.C.E.

FSc. Rajagopal, B. (2005). El Derecho Internacional desde Abajo. Bogotá: ILSA.

AP. Restrepo, E. (1918). "El último escolástico”. Publicado en la revista Voces, Mayo. Barranquilla.

AP. Revista de las fuerzas de policía de Colombia (1977). Bogotá, Marzo a abril.

FShp. Rivas, J.M. (1947). Miguel Antonio Caro, humanista. Bogotá: Voluntad.

FP. Samper, M. (1867). Miseria en Bogotá. Publicado en el periódico EL REPUBLICANO.

FSh. Sánchez, E. (1999). Gobierno y Geografía, Agustín Codazzi y la comisión corográfica de la Nueva Granada. Bogotá: Ancora. 
AP. Shütz, Günther (1987). "Miguel Antonio Caro en ediciones y estudios”. En:

Thesaurus, boletín del instituto Caro y Cuervo, Bogotá, sept-dic.

FShp. Sierra, R. (2002). Miguel Antonio Caro y la cultura de su época. Editor.

Bogotá: Universidad Nacional de Colombia

FSc. Sten, M. (1972). Las Extraordinarias Historias de los Códices Mexicanos, México: Joaquín Mortiz.

FSh. Todorov, T. (1987). La conquista de América. México: Siglo XXI.

FShp. Torres (1980). Caro defensor de la integridad del idioma, publicado en Obras Completas, T. III. Bogotá: Instituto Caro y Cuervo.

FSc. Twining, W. (2003). Derecho y Globalización. Bogotá: Siglo del Hombre, Pensar, U. Andes.

FShp. Uribe, M. T. \& Álvarez, M.(1987). Poderes y regiones: problemas en la constitución de la nación colombiana. 1810-1850. Medellín: Universidad de Antioquia

FShp. Uribe Uribe, R. (1985). La regeneración conservadora de Núñez y Caro. Bogotá: Instituto Luis Carlos Galán.

FShp. Valderrama, C. (1961). El pensamiento filosófico de Miguel Antonio Caro. Bogotá: Instituto Caro y Cuervo.

FShp. Valderrama, C. (1962). "El pensamiento de Miguel Antonio Caro". En: Obras (T. I). Bogotá: Instituto Caro y Cuervo.

FSc. Valencia, A. \& Ortiz, Á. (1997). Derecho Civil T.I, Parte General y Personas: Bogotá: Temis.

FSc. Vernant, J.-P. (1996). La muerte en los ojos, figuras del Otro en la antigua Grecia. Barcelona: Gedisa

FSc. Wasson, G.n; Hofmann, A. \& Ruck, C.(1995). El camino a Eleusis. México: F.C.E.

FSh. White, H. [1974] (2001). Meta-Historia. México: F.C.E.

FSh. White, H. (1992). El contenido de la forma, Narrativa, discurso y representación histórica. Barcelona: Paidos.

FSh. Windshuttle, K. (1997). The Killing Of History. N. York: Free Press.

FSc. Zizek, S. (2002). Mirando al sesgo, una introducción a Jacques Lacan a través de la cultura popular, Barcelona: Paidós. 

Esta obra se terminó de imprimir

en junio de 2016

con un tiraje de 500 ejemplares

en los Talleres Gráficos de

Grupo Editorial IbÁÑez

Carrera 69 Bis No. 36-20 Sur.

Tels: 2300731 - 2386035

Bogotá D.C. - Colombia 